Portland State University

PDXScholar

2-10-1986

\title{
Biostratigraphy of the Cowlitz Formation in the Upper Nehalem River Basin, Northwest Oregon
}

Neil B. Shaw

Portland State University

Follow this and additional works at: https://pdxscholar.library.pdx.edu/open_access_etds

Part of the Geology Commons, and the Stratigraphy Commons

Let us know how access to this document benefits you.

Recommended Citation

Shaw, Neil B., "Biostratigraphy of the Cowlitz Formation in the Upper Nehalem River Basin, Northwest Oregon" (1986). Dissertations and Theses. Paper 3654.

https://doi.org/10.15760/etd.5538

This Thesis is brought to you for free and open access. It has been accepted for inclusion in Dissertations and Theses by an authorized administrator of PDXScholar. Please contact us if we can make this document more accessible: pdxscholar@pdx.edu. 
AN ABSTRACT OF THE THESIS OF Neil B. Shaw for the Master of Science in Geology presented February 10, 1986.

Title: Biostratigraphy of the Cowlitz Formation in the upper Nehalem River Basin, northwest oregon

APPROVED BY MEMBERS OF THE THESIS COMMITTEE:

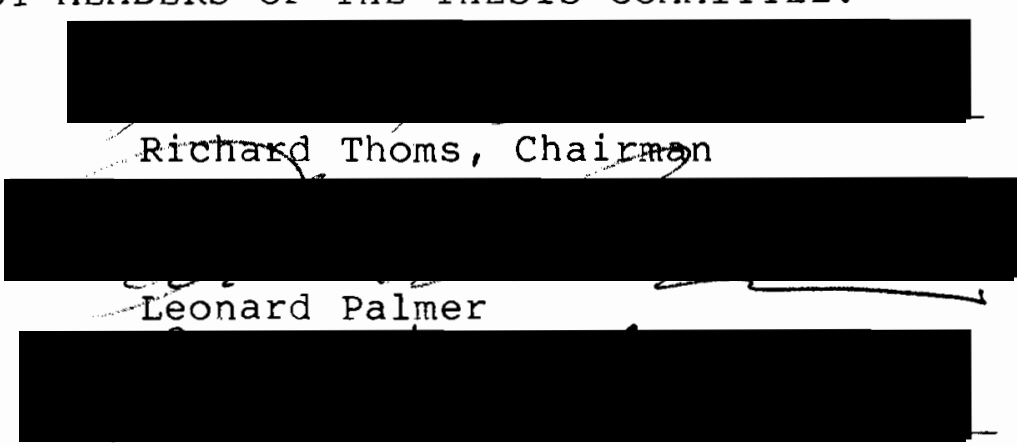

Robert Van Atta

Examination of stream and roadcut exposures of the Cowlitz Formation allows the selection of measured representative sections, and collection of fossils, from an area roughly defined by the intersection of the boundaries of Clatsop, Columbia, Tillamook and Washington counties in oregon. The study defines the features of the local environment of deposition, correlates sections to derive a composite columnar section, and develops a checklist of species for both microfossils and megafossils of the cowlitz Formation.

A composite columnar section of $720 \mathrm{~m}$, based on three stream sections and one roadcut section is 
presented. Twenty-two selected samples yielded fossil assemblages which included a total of forty-seven species of foraminifera, twenty-seven species of macrofossils and a small number of terrestrial plant fossils and trace fossils. Paleoecologically diagnostic species and assemblages indicate that the features of the environment of deposition varied. Water depth varied from upper bathyal or outer neritic in the lower Cowlitz Formation, to possibly inner neritic during deposition of the upper Cowlitz sands. Cool bottom temperatures and probably warm, stratified surface waters are also indicated.

The integration of paleontological and sedimentary structural evidence has resulted in (number) models proposed for the environment of deposition of the cowlitz Formation. A comparison of these models is made.

The composite section is assigned to the Narizian foraminiferal Stage of Mallory. Only one zone, the plectofrondicularia P. jenkinsi zone of Rau is recognized. It is represented by two faunules, the plectofrondicularia Lenticulina (lower) faunule, and the Cibides - Lenticulina (upper) faunule. A narrow overlap of the teilzones of Cyclammina pacifica Beck and Lenticulina texanus (Cushman and Applin) permits local correlation. One measured section, the sunset Camp Section, was continued across the Cowlitz-Keasey contact in order to achieve stratigraphic control. The Narizian-Refugian 
stage boundary appears to be coincident with this contact in this section. The fossils recovered from the Keasey Formation above the Cowlitz-Keasey contact were assigned to the Sigmorphina schenki zone of Rau. This contact is gradational and poorly defined. A marked reduction in mica characterizes Keasey rocks as well as the disappearance of the foraminiferal species Cibicides natlandi Beck, the occurrence of which is considered here to be diagnostic for the Cowlitz Formation.

The Cowlitz Formation in the study area can be correlated with the type Cowlitz Formation in southwest Washington, the Spencer Formation, Yamhill, the Nestucca and the Coaledo Formations of Oregon, the McIntosh Formation of washington and the Tejon Formation of California. 
BIOSTRATIGRAPHY OF THE COWLITZ FORMATION IN

THE UPPER NEHALEM RIVER BASIN, NORTHWEST OREGON

by

NEIL B. SHAW

A thesis submitted in partial fulfillment of the requirements for the degree of

\author{
MASTER OF SCIENCE \\ in \\ GEOLOGY
}
Portland state University
1986


THE OFFICE OF GRADUATE STUDIES AND RESEARCH:

The members of the Committee approve the thesis of Neil B. Shaw presented February 10, 1986
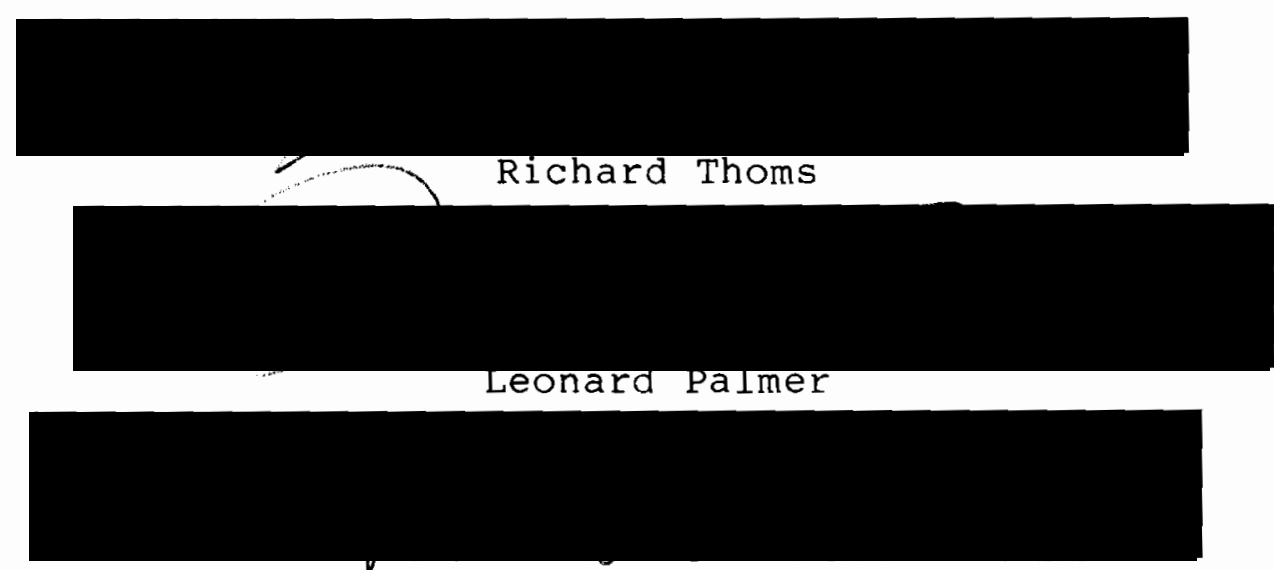

Robert Van Atta

Approved :

Paul Hammond, Head, Department of Geology

Dean of Graduate Studies and Research 
ACKNOWLEDGEMENTS

The author was aided in his work on this project by a number of persons and several institutions, all of whom cannot be named here. Those who come to mind most prominently are: Dr. Richard Thoms who suggested this project and whose company I enjoyed both in the field and in the laboratory; my wife Maureen who assisted me in the field and whose savings helped me to complete graduate school; and my parents who provided me with a pickup truck for my field work and who opened their kitchen to me for messy disaggregation work. I thank AMOCO Exploration Company and DOGAMI for lending financial support. Longview Fibre Company foresters in Vernonia generously provided me with air photos, directions, and permission to access their 1and. Dr. David Taylor provided much appreciated advice. Gina Luckey did a good job of typing this paper. Many thanks to Bob Johnson who gave me summer-long permission to camp on his property near Keasey. 
TABLE OF CONTENTS

ACKNOWLEDGEMENTS

LIST OF FIGURES

vi

LIST OF PLATES

vii

CHAPTER

I INTRODUCTION

I I GEOLOGY

Introduction 10

Tillamook Volcanics 14

Columbia County Quarry 16

$S \& P$ Railroad Cut 17

Cowlitz Formation 18

Nehalem River Section 22

Rock Creek Section 31

New Road slump section 38

Sunset Camp Section

Keasey Formation

I I PALEONTOLOGY

Foraminifera 58

other Fossils 
Plectofrondicularia - Lenticulina Faunule 65 Cibicides - Lenticulina Faunule 66

Environment of Deposition of the 67 Upper Sand Member

$\begin{array}{lll}\mathrm{V} & \text { AGE AND CORRELATION } & 79\end{array}$

Local Biostratigraphy $\quad 79$

The Narizian-Refugian Stag $ə$ Boundary $\quad 80$

SYSTEMATIC CATALOGUE

DESCRIPTION OF LOCALITIES 94

$\begin{array}{ll}\text { BIBLIOGRAPHY } & 101\end{array}$ 
LIST OF FIGURES

FIGURE

PAGE

1. Thesis Areas of Previous Workers 3

2. Thesis Area 5

3. Correlation Chart 11

4. Geologic Map of Thesis Area 12

5. Nehalem River Section 23

6. Nehalem River Columnar Section 24

7. Nehalem River Cross Section 25

8. Rock Creek Section 32

9. Rock Creek Columnar Section 33

10. Rock Creek Cross Section 34

11. New Road Slump Section 39

12. New Road Slump Cross Section 40

13. Sunset Camp Section 49

14. Sunset Camp Columnar Section 50

15. Sunset Camp Cross Section 51

16. Correlation of Sections 57

17. Checklist of Species 59

18. Deep Channel (Bruer) Model 69

19. Delta Face Model 69

20. Inner Neritic Model 70

21. Chan of Dott/Myers Model 72

22. Upper Bathyal Model 76

23. Bathymetric Curve 78 


\section{LIST OE PLATES}

1. Columbia county Quarry

2. Columbia county Quarry 15

3. $S$ and $P$ Railroad cut 17

4. Upper Cowlitz Sand

5. Soft Sediment Deformation

6. Leisegang Banding 43

7. Landsliding and Small scale faulting 43

8. Clay Parting

9. Unconsolidated "Clark and Wilson" Sand 45

10. "Chippy" Upper Mudstone 46

11. New Road slump 47

12. New Road slump 47 
CHAPTER I

INTRODUCTION

The northernmost portion of the Oregon Coast Range is characterized by an up-arched volcanic core, which has been named the Tillamook Volcanics Series (Snavely and Others, 1968). On the northeastern flanks of this volcanic high lies a series of marine sedimentary formations of Upper Eocene to Middle Miocene age. The oldest of these superjacent sedimentary formations is the Cowlitz Formation.

Although the Cowlitz Formation in Oregon was studied by such early workers as Diller (1896), who mapped the sedimentary units exposed in the bed of Rock Creek near Vernonia, comprehensive mapping and paleontological work did not take place until 1945 with the work of Warren and Norbisrath. Their map of northwestern oregon remains the standard to which all subsequent work has been compared. Van Atta (1971), Jackson (1983) and Timmons (1981) subsequently mapped the area in more detail, but modifications of the 1945 map have been minor.

The discovery of natural gas in the Cowlitz Formation near Mist, Oregon in 1979 spurred further interest in the 
presented. Twenty-two selected samples yielded fossil assemblages which included a total of forty-seven species of foraminifera, twenty-seven species of macrofossils and a small number of terrestrial plant fossils and trace fossils. Paleoecologically diagnostic species and assemblages indicate that the features of the environment of deposition varied. Water depth varied from upper bathyal or outer neritic in the lower Cowlitz Formation, to possibly inner neritic during deposition of the upper Cowlitz sands. Cool bottom temperatures and probably warm, stratified surface waters are also indicated.

The integration of paleontological and sedimentary structural evidence has resulted in several models proposed for the environment of deposition of the Cowlitz Formation. A comparison of these models is made.

The composite section is assigned to the Narizian foraminiferal stage of Mallory. Only one zone, the Plectofrondicularia P. jenkinsi zone of Rau is recognized. It is represented by two faunules, the Plectofrondicularia Lenticulina (lower) faunule, and the Cibides - Lenticulina (upper) faunule. A narrow overlap of the teilzones of Cyclammina pacifica Beck and Lenticulina texanus

(Cushman and Applin) permits local correlation.

One measured section, the Sunset Camp Section, was continued across the Cowlitz-Keasey contact in order to achieve stratigraphic control. The Narizian-Refugian 


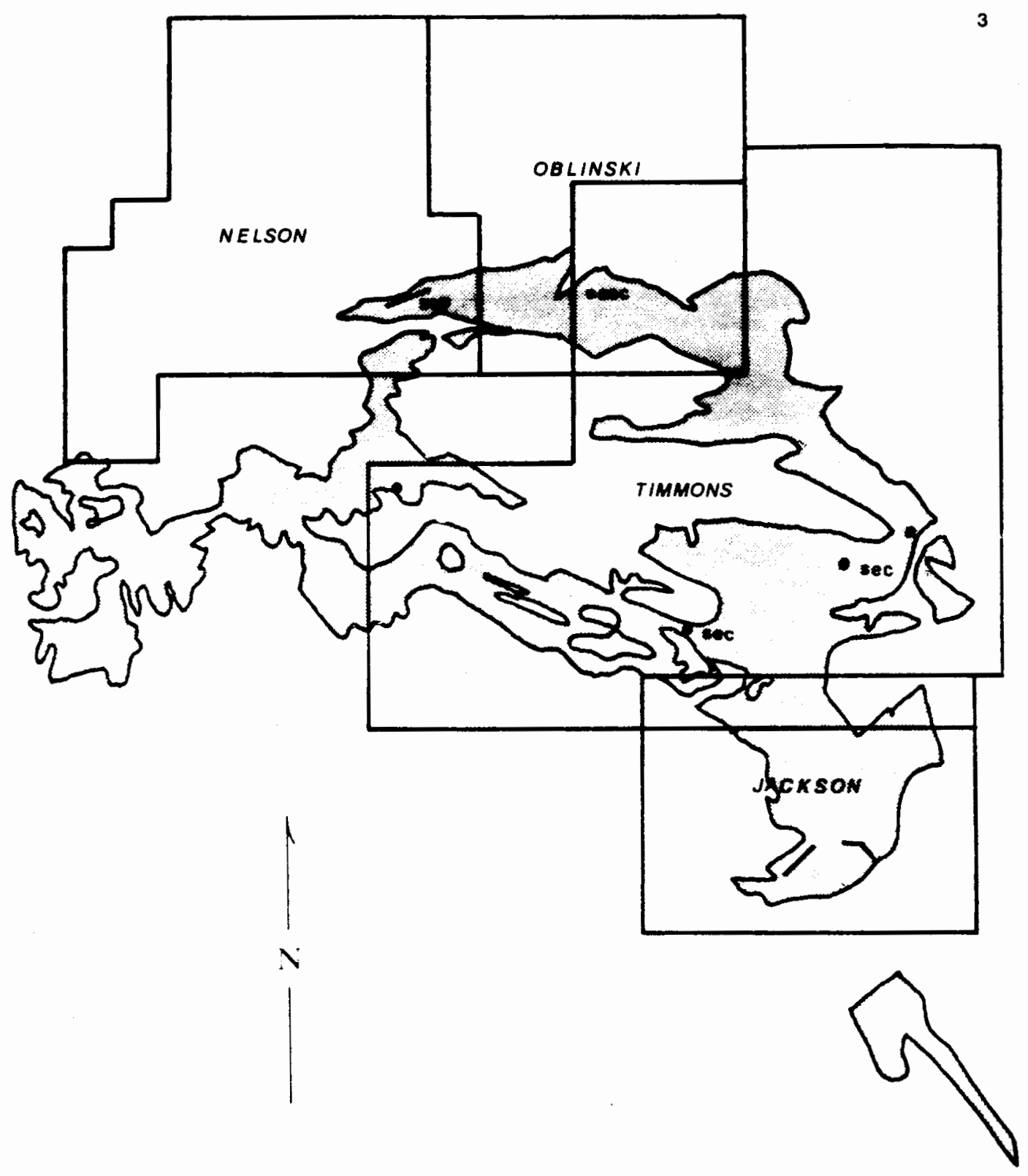

FIG.1 THE COWLITZ FORMATION AS IT OUTCROPS IN THE THESIS AREAS OF JACKSON, NELSON, OBLINSKI, AND TIMMONS. 
recently studied by Timmons (1981) and Jackson (1983). The reason for 1 imiting the study area as much as possible was that sections found close by one another geographically were apt to be more closely related lithologically and paleontologically, and therefore could produce a more rational composite section.

Figure 2 shows the several measured sections and collection sites of this project within the field area. This area is located almost entirely in the westernmost portions of Washington and Columbia Counties in oregon.

The field area is conveniently close $(50 \mathrm{~km})$ to Portland via U.S. Highway 26 (fig. 2). It is also generally well provided with good all-weather roads. Many of these are maintained by logging companies such as Crown Zellerbach Corporation and Longview Fibre Company. However, access is limited in some areas to those who secure permission from the companies involved. Macadamized county roads serve an area that has been important as a timber harvesting area since before the turn of the century. Landowners generally allow access to their private roads and riverside property. Rugged vehicles are recommended for all offhighway travel.

The upper Nehalem River Valley is oriented northsouth in the field area (fig. 2). This is controlled by the occurrence of erosionally resistant volcanic rocks of the 

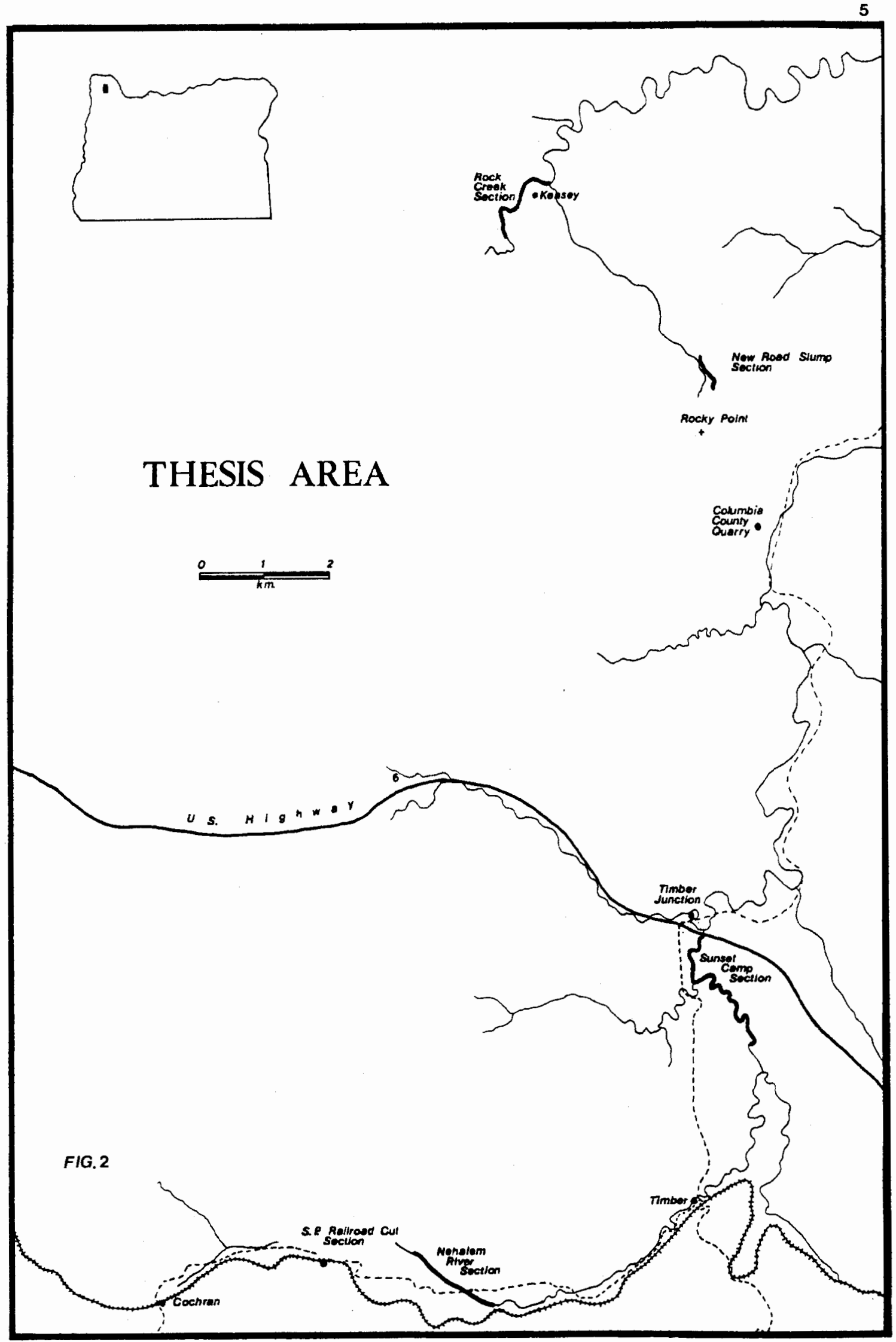
Tillamook Volcanics to the west. The Nehalem River and its tributaries erode the less resistent Tertiary sediments which lie to the east and exhibit the meander patterns characteristic of low-gradient stream flow. Faultcontrolled "diamond" drainage patterns characterize the indurated volcanic conglomerates exposed to the west of Timber. Dendritic patterns predominate in the volcanic highlands.

The thesis area is very heavily forested. Bedrock exposures are limited to the beds of streams and to fresh roadcuts and railroad cuts. High rainfall and humid conditions throughout most of the year cause rapid weathering and destruction of outcrops. Some formations such as the Keasey are particularly vulnerable to rapid weathering and subsequent landsliding.

\section{Field Work}

The field work for this project was completed during the summer and fall of 1984. Stream traverses yielded the best exposures of the Cowlitz Formation as well as superjacent and subjacent formations. In selecting appropriate sections, most of the tributaries of the Nehalem River in the field area were traversed. These included Rock Creek, Fall Creek, Wolf́ Creek, Louisinont Creek and the Nehalem River itself. Most of the possible sections examined could not be used for a variety of 
reasons including lack of stratigraphic control, extreme faulting, and/or excessive stream bedload cover.

Measurement of stream sections was made with the use of a 50 meter tape. Samples were taken from the stream bottom as required by the stratigraphy and at twenty-meter intervals within the more massive units. Bedding plane attitudes were taken with the use of a Brunton compass and a "dip stick." The "dip stick" was simply a three-foot length of one-and-one-half inch diameter dowel with small squares of plywood screwed to its ends at perfect right angles. This simple device made it possible to measure submerged bedding plane surfaces. When the lower plywood square was placed on a submerged bedding plane, the attitude of the upper, parallel plywood plane above the water level could be measured conveniently .

Road cuts offered many exposures of the cowlitz and Keasey formations as well as the Tillamook Volcanics, particularly in the Rocky point area where logging roads often yielded fresh exposures. However, road cuts were generally regarded with suspicion because of frequent landsliding and creep on the often steep, wet slopes of the highlands. One excellent, nearly continuous exposure of the upper Cowlitz Formation, including its contact with the superjacent Keasey Formation, was included here. Found near Rocky Point, and named the "New Road Slump" 
Section, it offered nearly vertical exposures of sedimentary structures in the Cowlitz Formation.

Maps used in field investigations included the USGS Clear Creek (1955) and Timber (1955) 7.5 minute quads. Also, recent (1984) aerial photographs at a scale of approximately $1: 12000$ were used for investigations in areas where logging roads had been very recently constructed.

\section{Laboratory Work}

One hundred-sixty-one samples were selected from three measured sections for disaggregation. Splits of all samples which yielded Foraminifera were isolated for storage at Portland State University. In addition to these samples which were taken to isolate Foraminifera, a number of samples containing mollusks, plant leaf and stem impressions, and some trace-fossils were collected. These fossils were isolated from their rock matrices and all poorly preserved specimens discarded. Well preserved specimens were given PSU location numbers, named, and deposited in the Portland State University Earth Sciences Museum.

Fine-grained rocks suspected of containing Foraminifera were disaggregated using the keroseneboiling water technique. Calcite-cemented rocks unaffected by this treatment were discarded. Eighty-two 
samples produced microfossils. Of these, twenty-two were selected as samples which contained representative species assemblages within critical stratigraphic intervals. Sampling sites were given Portland state University location numbers. Hypotype slides and assemblage slides of Foraminifera were prepared and deposited in the Portland State University Earth Sciences Museum. 


\section{CHAPTER I I}

\section{GEOLOGY}

\section{Introduction}

The Cowlitz Formation, a thick sequence of mostly continentally derived, micaceous, arkosic sediments of Eocene age is exposed in the Keasey-Timber-Cochran area on the eastern flank of the Tillamook Highlands of the northern Oregon Coast Range. Partial exposures of the Cowlitz Formation along the tributaries of the upper Nehalem River yield a composite stratigraphic thickness of $720 \mathrm{~m}$. The Cowlitz is typically found at lower elevations; the highlands to the west are largely occupied by the basalts and volcaniclastics of the Tillamook Volcanics which underlie the Cowlitz. Easterly, the Cowlitz Formation is overlain by the tuffaceous, poorly-micaceous mudstones of the Keasey Formation.

The Coast Range Province of northern Oregon is characterized by a series of marine sediments and volcanic rocks which have been folded into a broad anticlinorium. This structure plunges to the north of the Tillamook Highlands. The central portion of the anticlinorium is occupied by the volcanic flows, breccias 


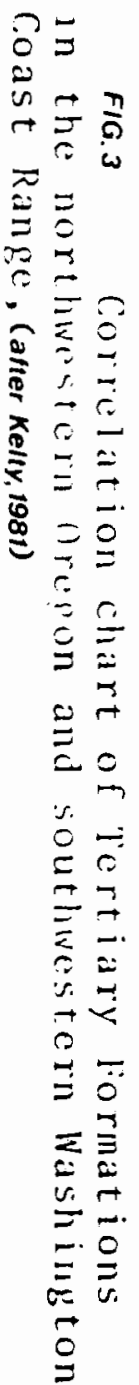

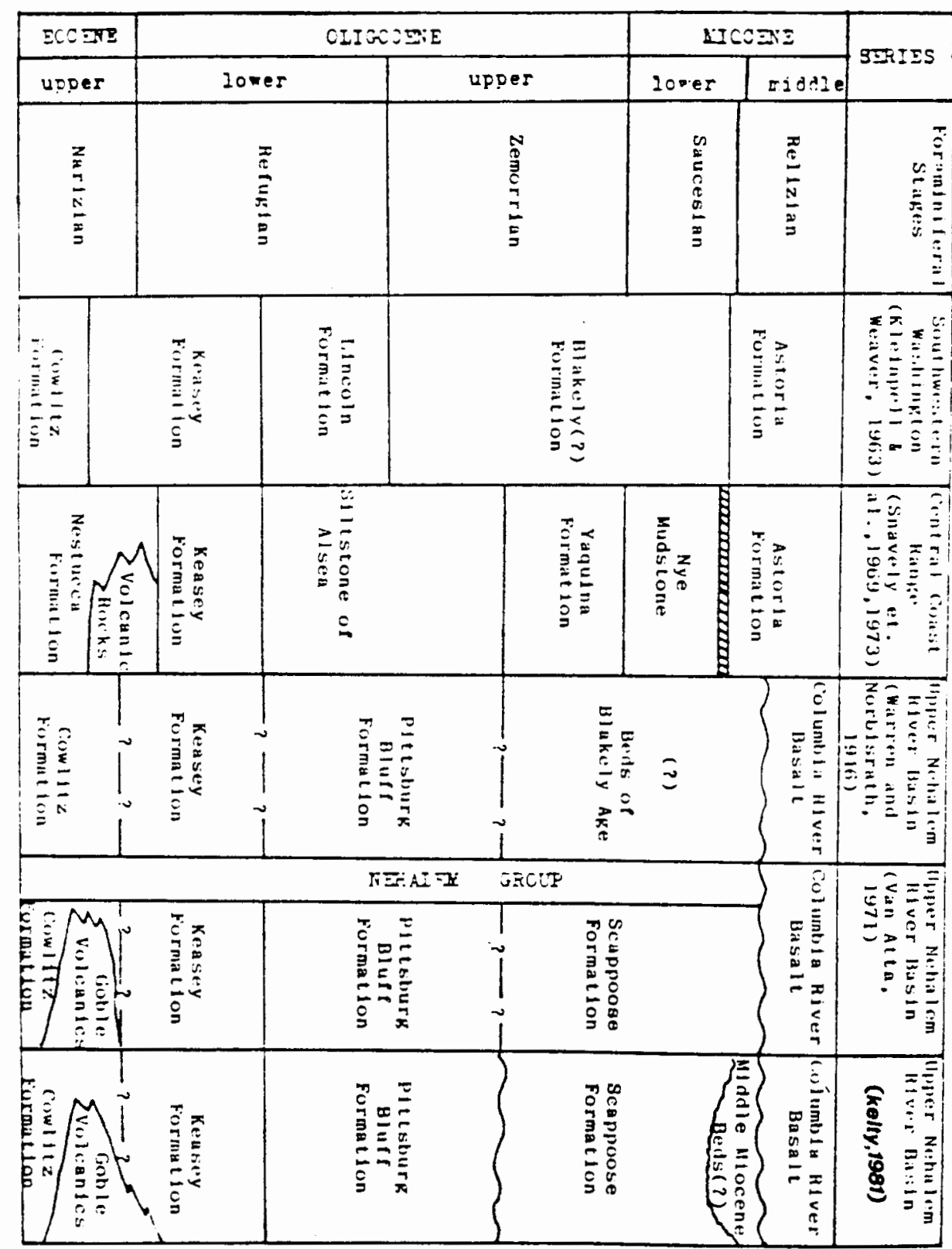




\section{THESIS AREA FORMATIONS}

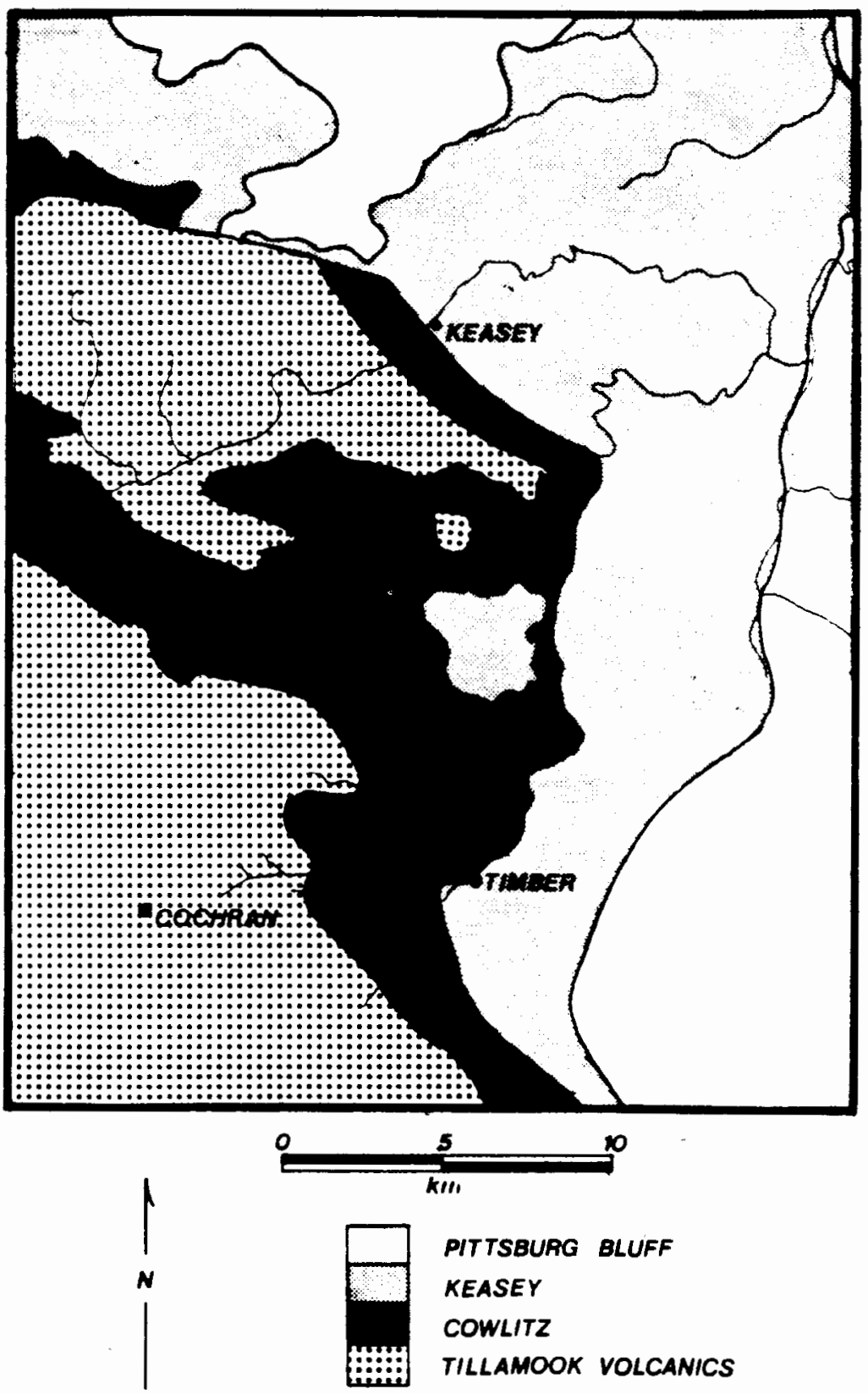


and sediments of the Tillamook Volcanics. Draped around the nose of the structure to the north is a sequence of younger Tertiary sedimentary formations called the Nehalem Group by Van Atta (1971). From oldest to youngest this group includes the Cowlitz Formation of late Eocene age, the Keasey Formation of Late Eocene to early Oligocene age, the Pittsburg Bluff Formation of middle Oligocene age, and the Scappoose Formation of middle Miocene age (fig. 3). The Scappoose Formation interfingers with and is capped by flows of Columbia River Basalt deposited during middle Miocene time.

The Cowlitz Formation in the Nehalem River basin outcrops in a discontinuous arc surrounding the highlands of Rocky Point (fig. 1). This outcrop configuration in map view does not indicate the true lateral extent of the formation, which is somewhat greater when subsurface occurrences are included. The cowlitz Formation is thickest in subsurface several kilometers to the north of the field area near Mist (Bruer, 1984).

This study is based on four measured sections and two sample sites. These were selected to provide a composite columnar section of the Cowlitz Formation including its contacts with the Tillamook Volcanics and the Keasey Formation. These sections were then positioned relative to one another based on an observed species range overlap of two Cowlitz Formation Foraminifera. 
These two species were Cyclammina pacifica Beck, which was found in the lower part of the Cowlitz and the other Lenticulina texanus (Cushman and Applin) which was found in sections which included the upper Cowlitz.

Tillamook Volcanics

The Tillamook Volcanics (Snavely and others, 1968) is an accumulation of Eocene basaltic flow rock, minor pyroclastics, breccias, mudflows, conglomerates, tuffs, and minor volcanic sediments which represent the products of alkali-basaltic volcanism. It has been concluded by Jackson (1984) that the Tillamook Volcanics rocks are similar to oceanic volcanic piles such as the Galapagos Islands and Iceland. In fresh hand sample the basalts and basaltic andesites of the Tillamook Volcanics Series are typically medium grey, aphanitic to somewhat porphyritic, often exhibiting large plagioclase crystals. Flow rocks tend to weather to a dark orange "rust" color. In this report, strata of the Tillamook Volcanics are found in depositional contact with the overlying Cowlitz Formation in the Nehalem River Section, the $S$ and $P$ Railroad Cut, and in fault contact with the Cowlitz in the Rock Creek Section. The basalts of the Columbia County Quarry, also referred to in this report, may represent a slide block of Tillamook Volcanics rock which came from 


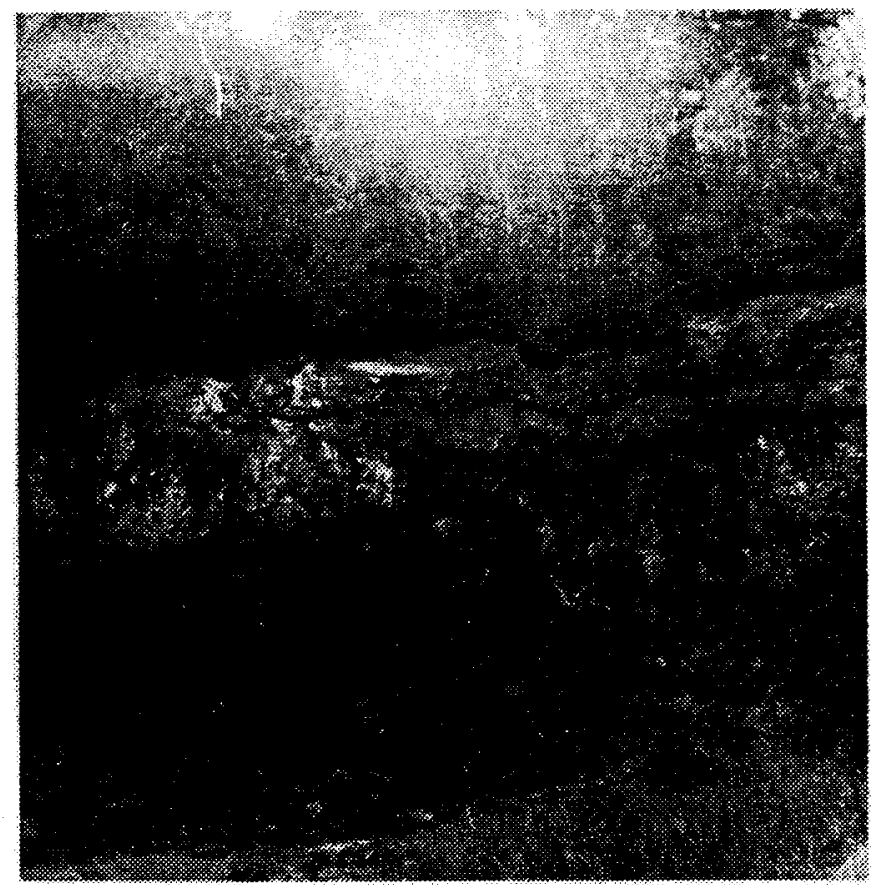

p. 1

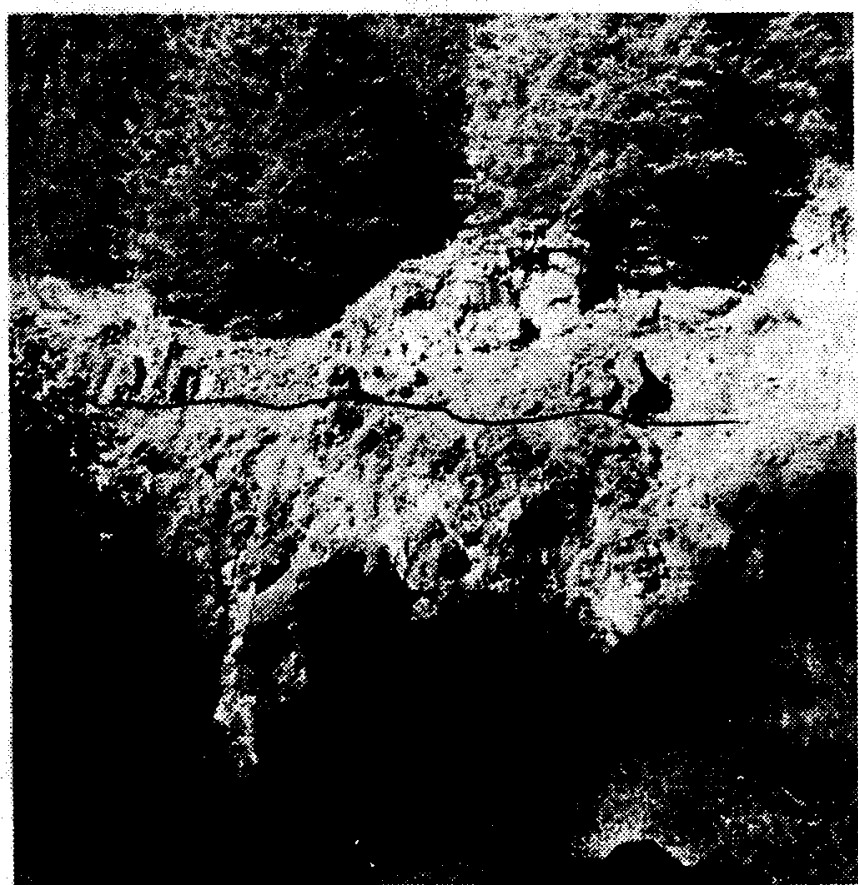


Rocky Point, a local high of Tillamook Volcanics flow rock immediately to the west of the quarry (Timmons, 1981, p. 35) .

Cowlitz-contemporary volcanic rocks have been referred to as the Goble Volcanics (fig. 3). Goble Volcanics rocks are so similar to Tillamook Volcanics rocks that differentiating between them is very difficult, even with the use of trace-element (INAA) geochemical techniques (Jackson, 1984).

A small quarry near Rocky Point (fig. l) (plate l) exposes two layers of basalt which may be either Goble Volcanics or Tillamook Volcanics (plate l). Between the two layers there is a discontinuous boulder to pebble conglomerate of variable thickness (top of outcrop, plate 1). The conglomerate and associated sediments have a distinctly reddish color (plate 2). The conglomerate layer, as well as a rubbly zone on the northwestern rim of the quarry offers a variety of fossils of inner neritic and littoral zone animals such as Ostrea, Volsella, Mytilus, and Terebratalia.

This quarry has been examined by many geologists and paleontologists. Van Atta (1971), Nelson (1977), and others have interpreted this outcrop (plate 2) to represent an intrusion of Goble basalt into mudstone and conglomerate, the conglomerate between the basalt 
layers representing a "sliver of intrusionalisplacen host rock" (ximmons 1981, p. 19).

Timmons Einds that the hasalt layers represent

subagueous or subaerial Elows, probably in a littoral zone. Sulfide mineralization in the conglomerate and sedimentary layer; angular, apparentiy autobrecciated rubbla; and the pressnce of red, higher oxidation state (ferric) jron oxida; all suggest a subaerial or submarine flow, as opposed to an intrusion.

A large, (up to $30 \mathrm{~m}$ ) nearly vertical bank along the 5 \& Railroad track near Cochran (mate 4 ) offers an excellent exposure of upper Eocene sedimentary material which contains many fossils of stems and leaves of treas and other plants.

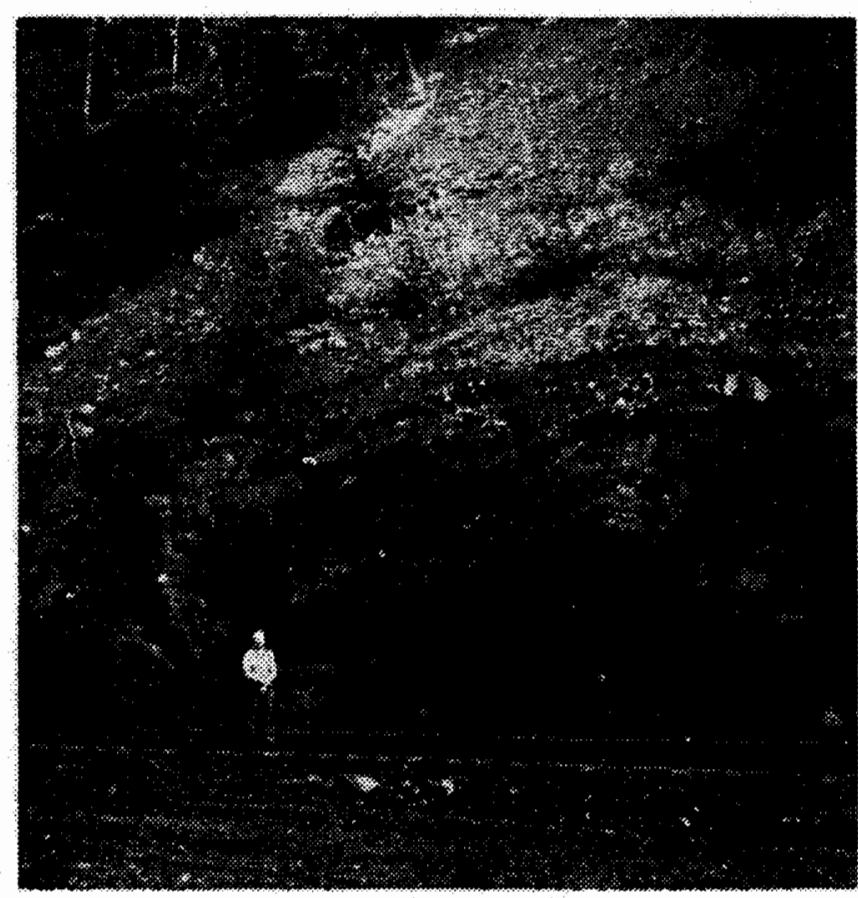


Jackson (1983), mapped this outcrop as part of the Tillamook Volcanics Series. This author, however, is inclined to group this outcrop with the conglomeratic basal member of the Cowlitz Formation, using Warren and Norbisrath's definition of local conglomerates in the Cochran area.

The lowermost portion of this outcrop is composed of a dark, greenish-grey, very poorly sorted volcanic sand with included boulders. This volcanic sand and boulder assortment is sharply defined at its uppermost limit by a distinct plane, forming an indurated shelf in places. Overlying this is a poorly sorted conglomerate containing rounder cobbles and boulders interstratified with light tan, tuffaceous, bedded siltstone. The siltstone beds yield the numerous plant fossils mentioned above.

Plant forms in the $S$ and $P$ Railroad cut include the abundant reed Lastera, the common sycamore-like tree Planatophyllum, abundant scouring rush Equisetum (the Eocene forms were much larger than those found in the Coast Range today), and the cypress Chamaecyperus (Cameron, 1977).

Cowlitz Formation

The Cowlitz Formation in the Nehalem River Basin can be divided (Warren \& Norbisrath, 1946) into four informal members based on lithology: a basal conglomerate, a lower mudstone, a sandstone, and an upper mudstone which 
grades into the overlying Keasey formation. The Cowlitz in the study area is characterized by an abundance of mica even in very fine-grained samples. This aids in distinguishing it from the overlying basal Keasey formation which is mica-poor. In the field, this is frequently the only feature which can be used to locate the CowlitzKeasey contact. (Van Atta, 1984)

The name Cowlitz, as used to designate the upper Eocene sediments in the upper Nehalem River basin, was a problem almost as soon as it was first used by warren and Norbisrath in 1946. Deacon (1954) formally called this name into question by noting lithological differences between the typical Cowlitz Formation in washington and those strata which interfinger with volcanic rocks in Rock Creek in the study area. He proposed, alternatively, the name Rocky Point Formation (Rocky Point appears in the center of a ring of Cowlitz Formation outcrops in the Nehalem River basin). Niem (oral comm. 1984) also called the name into question, citing paleontological differences, most notably the presence of the deep-water form Plectofrondicularia packardi Beck in the Nehalem River Basin, and its complete absence in the type-Cowlitz sediments of Washington. Van Atta (1971), however, in his study of the Tertiary formations in the upper Nehalem River Basin favorably compared type-Cowlitz Formation strata with those in Northwest Oregon and found the 
similarities between the two to be so great that a name change was unnecessary. The name remains in place to this writing.

Basal Conglomerate - The basal conglomerate frequently found at the contact between Tillamook Volcanics strata and the Cowlitz Formation is highly variable in both thickness and lithology. The thickness varies from zero to more than 60 meters, the figure given by Warren and Norbisrath (1946). In the headwaters of the Nehalem River where it apparently follows the straight line of a fault west of Timber (fig. 2) the basal conglomerate thickness exceeds 200 meters. The possibility exists, however, that normal faults have repeated the section; normal fault scarps are evident in many places along this portion of the river.

Lithologically, the conglomerate can vary from well cemented boulder conglomerate to unconsolidated, poorly sorted, angular volcanic sand. Clasts may be in matrix support or in clast support. Much of the conglomerate found in the river bottom west of Timber is poorly sorted boulder to cobble orthoconglomerate in a volcanic sand matrix. Typical conglomerates contain a mixture of tholeite basalt clasts of aphanitic to porphyritic texture, and dark greenish-black color, to lighter grey basaltic andesite. Vesicular basalt clasts are usually present also. Any attempt to generalize about the nature of this material is 
thwarted by the variety which exists. The lithologic descriptions presented in the Nehalem River Section describe the lithologies involved in greater detail. Lower Mudstone Unit - The composite section produced for this report (fig. 16), has a thickness of approximately two hundred meters for this member. This agrees well with the Quintara Watzek $30-1$ well logs (Mist gas field, $17 \mathrm{~km}$. to the north) which indicate a unit thickness of 210 meters (Olbinsky, 1983). This figure also agrees with the "typical well section, east Nehalem Basin" of McKeel, (fig. 11983 p. 3).

This unit is described as a shale by warren and Norbisrath (1946), as a sandstone/mudstone by olbinsky (1983), as the lower sandstone member by Nelson (1984) and as a siltstone unit by Van Atta 1971). This author found the unit to contain primarily claystone at the base, grading upward into a long sequence of mudstone, and thin, laminated, interbedded siltstone and fine sandstone beds.

The unit is organically very rich and it has been suggested that it is the source rock for the natural gas accumulations in the nearby Mist gas field (Bruer, 1980). Lignite laminae occur prominantly in the upper portions of the unit, and the dark mudstones and siltstones of this unit were observed by this author to mold'like cheese when stored in air-tight cartons. Cowlitz mudstones have been shown to have hydrocarbon contents exceeding one percent 
(Armentrout and suek table II, 1984). Vitrinite reflectance values are low, however, indicating that the thermally generated gas at Mist probably has a more distant provenance.

The color of the sediments in this unit are predominantly dark grey in the massive siltstone units. Claystones were generally lighter grey, even bluish, and the laminated sandstone/lignite/siltstone units were variable with often marked contrast betwen light tan arkosic sediments and darker grey mudstone and lignitic layers. Weathered samples were often a dull yellowishbrown color which tended to obscure rock types in river banks and roadcut exposures.

Paleontologically this unit is rich. The finer grained sediments yielded most of the foraminiferal species found in this study. Megafossils are abundant also, best represented in this report in the sunset Camp section. Trace-fossils such as Chondrites and Helminthoidea are also found in this lower mudstone unit. Leaf fossils are reported in the unit by Jackson(1983) but were not observed by this author.

Nehalem River Section

A stream section was selected three miles west of Timber in the upper reaches of the Nehalem River (little more than a shallow creek at this point) (figs. 2, 5). This 


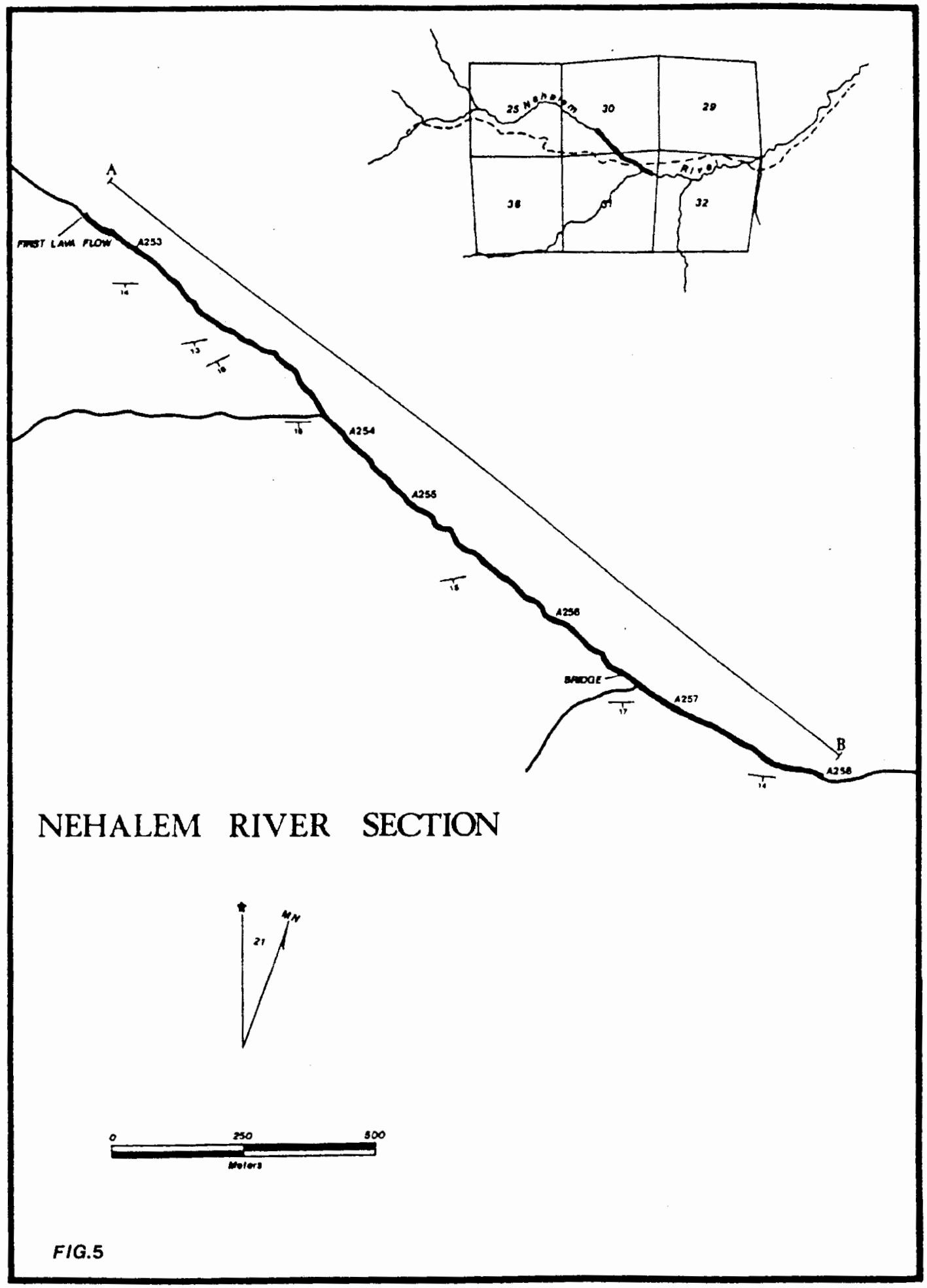




\section{NEHALEM RIVER SECTION}

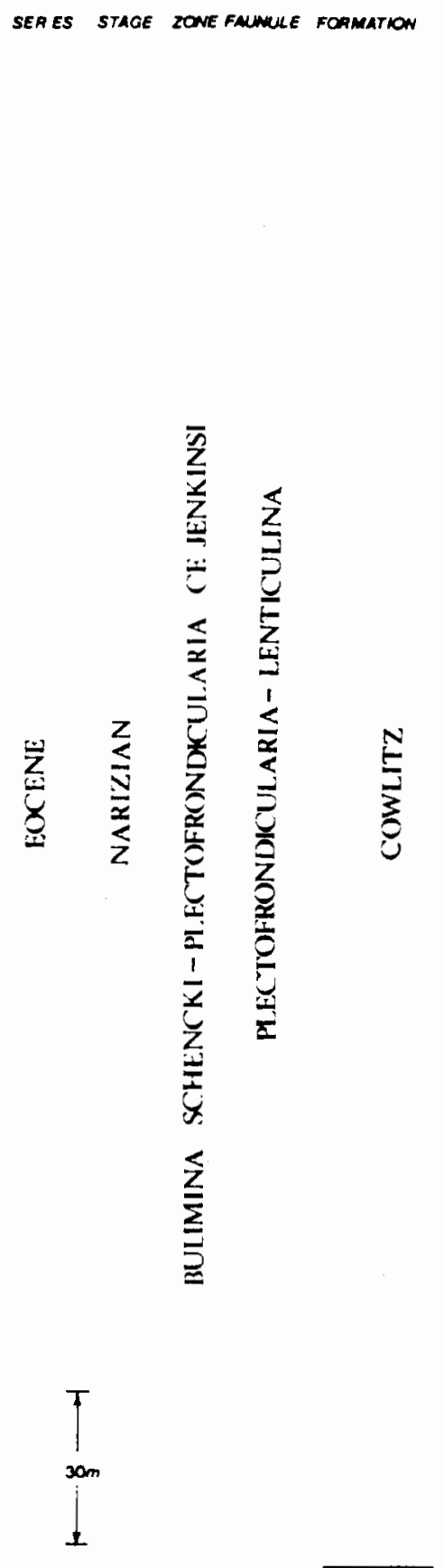

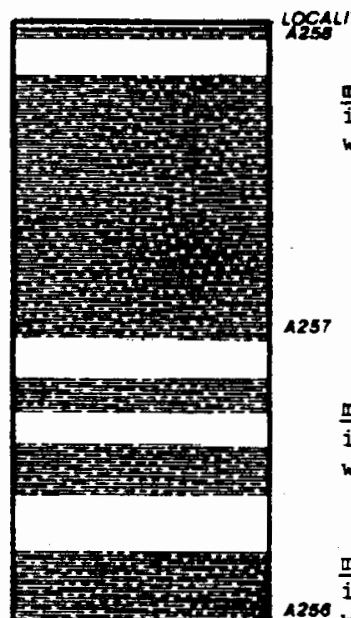

mudstone-well bedded, motudr grained, poariy inturated, metiun grey fresh, red-bram wothered, interofossilliferous.

mudstone-well bedded, medium grained, poorly indurated, medium grey fresh, reddish-brown weathered, micrafossiliferous.

modstone-ull bedded, medium grained, poorly inturated, mediun grey fresh, reddish-bran 1230 weathered, carbonaceous, ulcrofossiliferous.

mudstone-poorly bedded to massive, fine grained, medium grey fresh, reddish-brown weathered, microfossiliferous.

1255 mudstane-well bedded, fine grained, medium blue-grey, "chippy" weathered appearance, uricrofossiliferas.

1254

mudstone-massive, fine gradned, mediu grey-bran, pelecypod monds, microfosslliferous.

conilomerate-boulder (to lo) clasts in sand matrix, very well indurated. conglonerate-sebbie to cobble clasts in sand matrix sipport, well incurated.

sandstone-very poorly sorted, angular, mon-indurated, black, well bedded.

conglonerate-poorly sorted sand-pebble clasts.

sandstone-massive volcanic, poorly sorted, well indurated, allve green fresh. conglomerate-baseltic pebble clasts.

12ss sflitstane-volicante, carbonaceous, microfoesdilferous.

sandstone-valicanic, poorly sarted.

canlomerate-pebble-cobble andesite \& basalt contact-Tillamook Valcanico-Cailytz Form. 


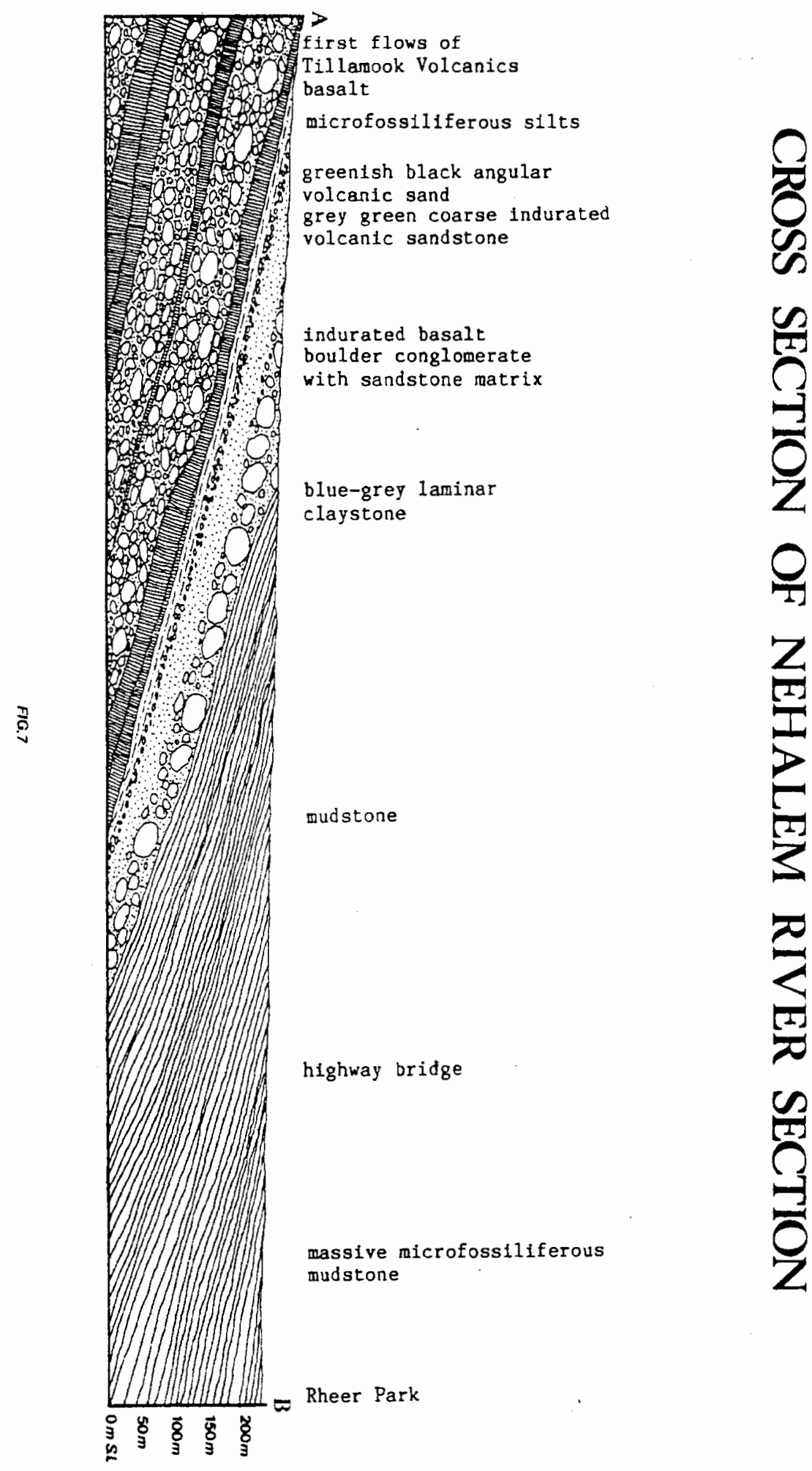


section was selected in part to represent the Tillamook Volcanics - Cowlitz Formation contact. Other desirable features of this traverse were the excellent exposures of basal conglomerate, as well as the fact that the dip direction of the strata was found to occur at a fairly low angle to the axis of the stream. This nearly optimum relationship of dip direction to stream course found at the northwest end of the traverse is lost to the southeast, however, where the section was terminated.

The Nehalem River at this point is obviously not strike-controlled as it is in the sunset Camp section, but is instead fault-controlled. The stream course is exceptionally straight, and in places cuts steep-sided "slots" in the hard conglomerate of the lower Cowlitz Formation. This strongly suggests that it is followingfault gouge zones. Also, intersecting normal faults are apparent in the northwestern part of the section. These are indicated by distinct faultine scarps (to $1 \mathrm{~m}$ ) as well as the linear configuration of branch streams which apparently follow these faults.

The Nehalem River Section is approximately $1800 \mathrm{~m}$. in length and represents a stratigraphic thickness of about $275 \mathrm{~m}$. (fig. 6) Dips are generally southward and vary from 14 to 17 degrees (fig. 7). The stream bed is as wide as 25 meters where the river widens in the soft sediments at the southeastern portion of the traverse, to 
as little as 2 meters where it cuts small gorges in the conglomerates and basalts of the northwestern portion. The stream bottom is largely obscured by a bedload of basalt cobbles and small boulders.

The Nehalem River section presented a highly varied and interesting sequence of strata. As indicated above, the section can be divided into a volcanic and conglomeratic portion and a claystone-siltstone-mudstone portion. The volcanic, conglomeratic segment can be further subdivided based on the strikingly variable nature of the beds which one encounters.

The volcanic conglomeratic portion of the section represents 90 meters of strata. It contains sedimentary beds of fine siltstone to well-sorted large boulder conglomerate $(1.5 \mathrm{~m})$. It is roughly comprised in equal proportion of well sorted cobble to boulder conglomerate and poorly sorted volcanic sandstone with pebble to cobble inclusions.

The traverse begins somewhat arbitrarily with a thin, massive basalt flow exposed in the river bank. However, subrounded to subangular cobble to boulder conglomerate is exposed upstream for at least another half kilometer from this point. Upstream, near the $S \& P$ railroad cut section (fig. 2), conglomerate appears again, suggesting a great thickness of this member in this locality. 
Approximately 25 meters downstream from the thin basalt flow which marks the beginning of the traverse, appears a massive, thick $(6 \mathrm{~m}$.$) bed of dark, greenish-$ black, unconsolidated, poorly sorted, extremely angular, coarse basaltic sand. This material is somewhat weathered and consequently impermeable.

Below this appears a very well indurated, calcitecemented pebble to cobble conglomerate which extends for some 60 meters. This is followed by a light olive green, poorly sorted volcanic sand which continues for another 50 meters. Subsequently a short sequence of pebble to cobble conglomerate appears, followed by a striking layer of loose, black, coarse, basaltic sand. Crude bedding planes are apparent in this bed, but the orientation of clasts is random. This sand is chemically fresh and highly permeable with a stratigraphic thickness of less than 3 meters (fig. 6).

A short covered interval gives way to a tan, finegrained, well bedded siltstone from which foraminifera were isolated (PSUA 253).

A pebble to cobble conglomerate is exposed for 10 meters. This gives way to a long $(450 \mathrm{~m})$ sequence of poorly sorted, light olive-green volcanic sand. This material is well indurated with calcite and clay cement and in places forms cliffs and benches along the river. It is unfossiliferous. 
Another short covered interval of 30 meters downstream reveals a conglomerate series which is unbroken till the laminated claystones of the fine grained sedimentary sequence appears some 110 meters below. The size of clasts in this conglomerate grades upward from pebbles in the lowermost portion of the unit (upstream) to huge boulders ( 1.5 meters) in the central portion. A cobble and small boulder conglomerate appears near the top (downstream). It is here that the stream cuts deep slots in the bedrock and where exposures are best in nearly vertical cliffs. Also faults are strikingly apparent here, in part because the rock is so indurated and therefore resistant to erosion.

Claystone-siltstone comprises the bulk (185 m) of the Nehalem River Section (fig. 6) At its base it is well bedded, even laminar in places as well as being very fine grained and clay-rich. Its color is bluish grey. It is microfossiliferous, including sample sites PSUA254, and PSUA255 (see checklist for species occurences).

The uppermost portion of the unit shows much more sedimentary structure than the underlying massive siltstones and clay stones. This probably reflects a higher energy environment of deposition. In addition to the thin laminated strata, mentioned above, sandstone layers exhibit ripple cross-lamination. Jackson (1983) also 
found structures resembling hummocky cross stratification on a small scale here.

Sands and silts of this unit are micaceous, containing both biotite and muscovite. The sands are compositionally mature (Van Atta, 1981) and moderately well to well sorted. These sands are not very permeable, however, (Armentrout 1983) due to the inclusion of volcanic lithic fragments.

Sandstone Unit - The sandstone unit of the Cowlitz is typically a highly permeable stratum (averaging 200 ma to $1500 \mathrm{md}$ ) (Newton and Van Atta 1976) and is the target unit of the Mist gas field. The unit is composed of fine to medium grained micaceous, quartzose sand. It is remarkable by virtue of its lack of lithic rock fragments and clay material.

This unit is very poorly consolidated, leading to frequent slumping of incompetent banks along roads and streams. This yields many fresh exposures wherever the upper Cowlitz outcrops.

The unit is best exposed in the New Road slump section of this report. Here it is clearly separated into two subunits herein called the "Clark and Wilson sand" (lowermost) and the upper Cowlitz sand. These are separated by dense claystone layers which effectively isolate them from one another in the gas wells of Mist (Townley, oral comm. 1984). Olbinsky (1983) and Nelson 
(1984) also distinguish between the two subunits based on petrology. They refer to the lower subunit as the "zircon rich" sandstone and to the upper as the "epidote rich" sandstone. In the New Road slump section the unit is at least 150 meters thick, but this appears to be highly variable since the sunset Camp section nearby offers less than fifty meters of sand. Additionally the sandstone of the sunset Camp section is less recognizable as a sand unit in the field, being finer grained and much darker.

Rock Creek Section

This section was included here because it represents a typical sequence of sediments of the transitional or heterolithic strata intermediate between the upper sandstone member and the lower mudstone members. Large displacement normal faults are involved in this section, particularly at the Tillamook Volcanics - Cowlitz Formation contact where upper Cowlitz sediments are faulted against Tillamook Volcanics flow rock (fig. 10). This gives the appearance that the stratigraphic column is being "stood on its head," as shown in the cross section (fig. 10). Also abrupt attitude changes near the town of Keasey (fig. 8) and slickensided samples from the stream bottom indicated faulting, demanding a termination of the traverse. Stratigraphic control could not be established, leaving this section as a "floater." 


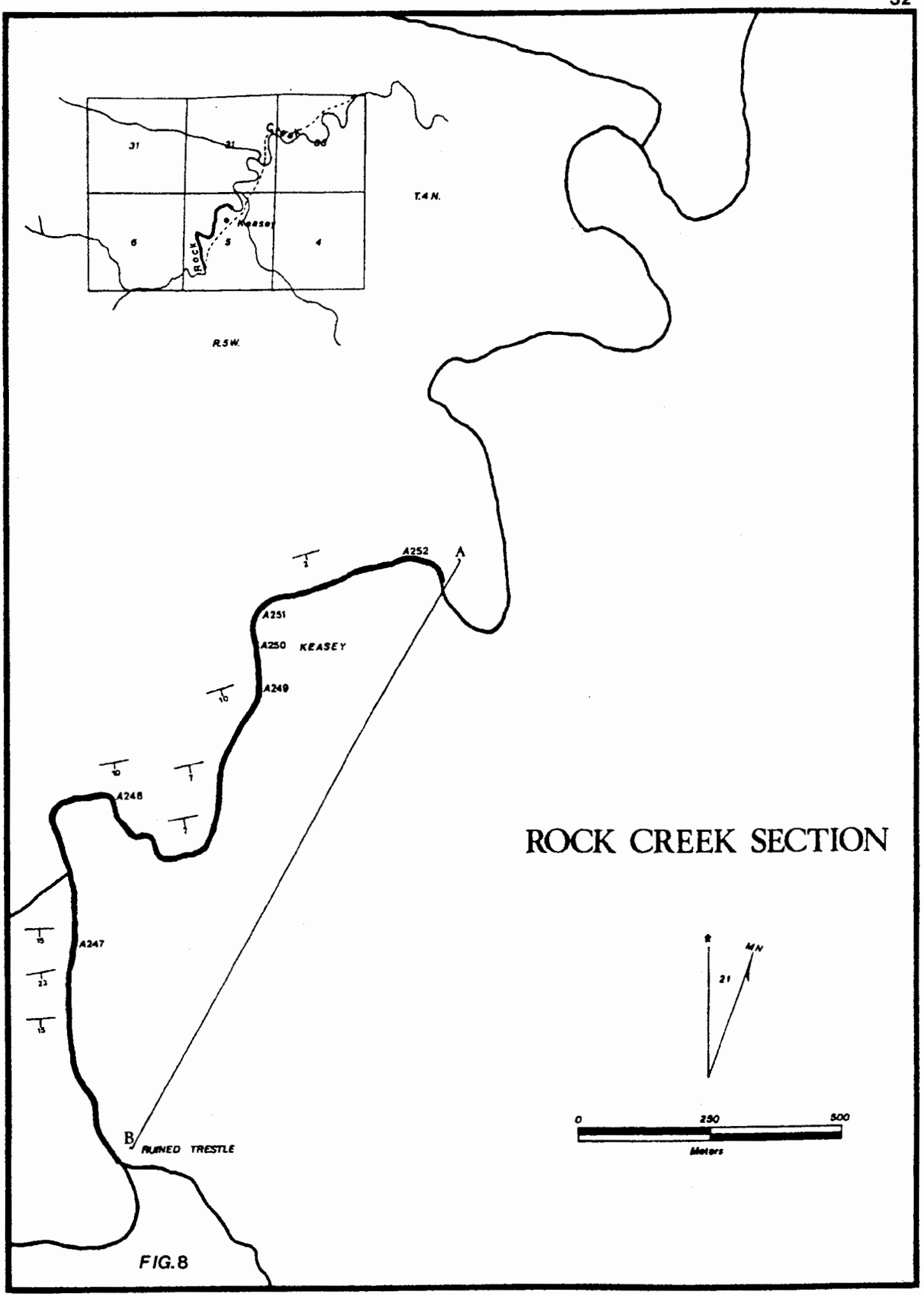




\section{ROCK CREEK SECTION}

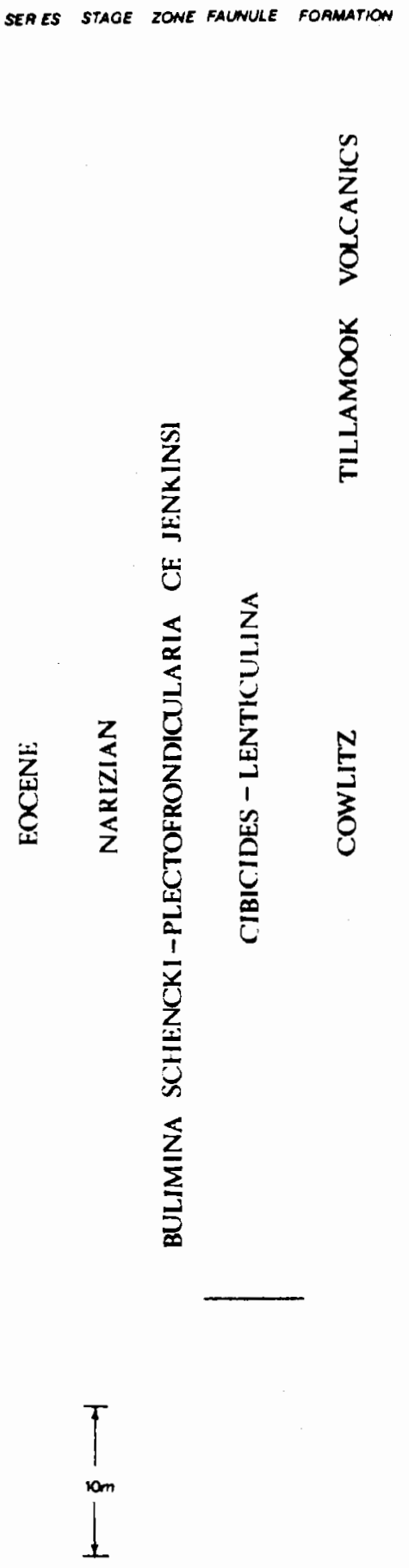

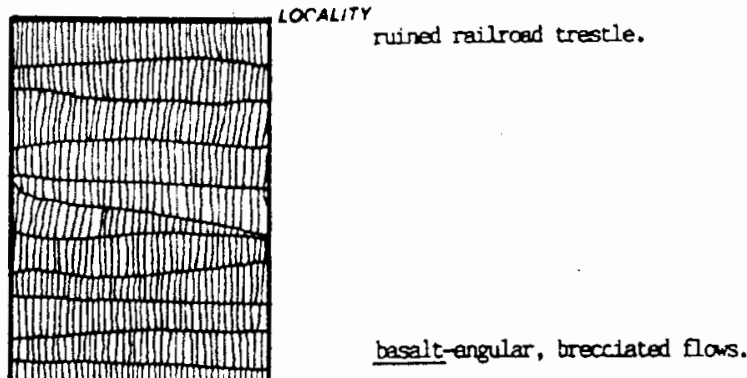

fault-large displacement normal.

sandstone-massive, poorly indurated, fine grained, very micaceous, light grey.

sandstone-bedded,very friable, medium grained, very micaceous.

siltstone-ll bedded, very friable, medim grained, aicaceous.

sandstone-massive to bedded, well indurated, ricaceous.

siltstone-laminated, friable, meciim grained, micaceous.

silistone-iaminated, friable, micaceous carbonaceous, medium grained.

Siltstone-lamirated, moderately in: duraced, medium-coarse grained, light grey fresh and wathered.

sandstane-laninated, well indurated, poorly uricaceous.

sandstane-mass ive and cross bedded, poorly indurated, medium grained and weathered, large (Im) concretions. sandstanewell bedded, friable, medium grained,

slickened samples here. siltstane-well bedded, friable, medium grained, indcaceous, medium grey.

\section{0}

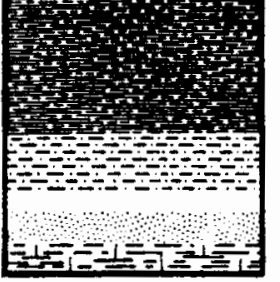

\section{A231}

Siltstone-messive, friable, coarse grained, micacens. sandstone-bedded concretionary, medium gratned,nan-micaceous, quartzose, very light grey. siltstone-massive, concretionary, nedium grey. 


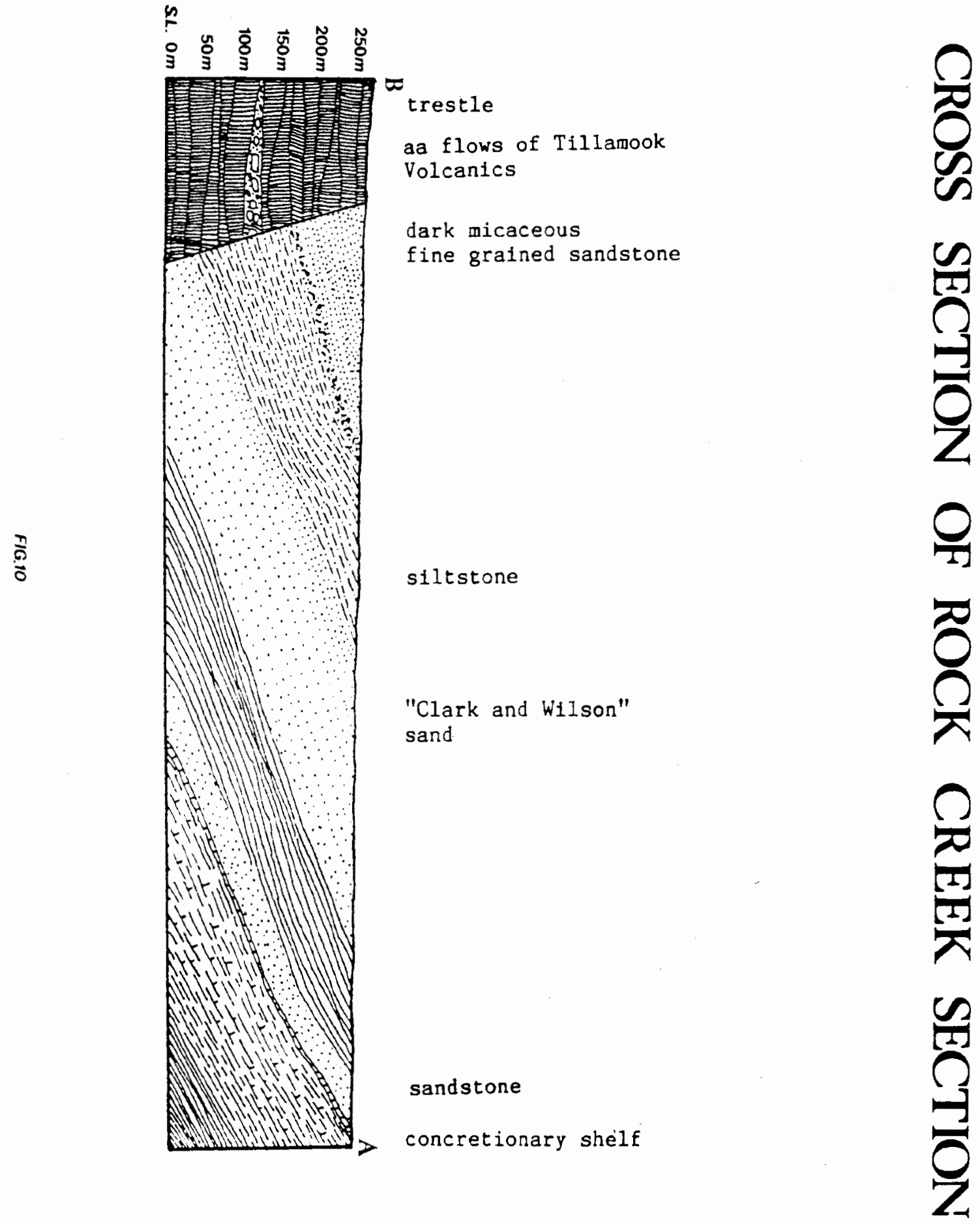


The Rock Creek section is located about fifteen kilometers southwest of Vernonia, and adjacent to Keasey. The type section of the Keasey Formation was established downstream northeast of Keasey, just a few hundred meters from the termination of this section. The stream is clearly strike controlled here, exhibiting lineations along a northeast-southwest axis (fig. 8). Dips to the south are quite variable from a minimum of 7 degrees to a maximum of 25 degrees. As mentioned before, dips are opposite to that expected. That is, it would be expected that sediments dip away from the volcanic high to the south as they do in other parts of the study area. This leads to the conclusion that faulting is a serious problem in this section, and also that measured section thicknesses are highly questionable. The section's rich foraminiferal representation, as well as good exposures of representative lithologies, however, justify its inclusion here.

This Rock Creek Section traverse covered nearly two kilometers, but meanders along strike-controlled portions of the stream and the inclusion of Tillamook Volcanics flow rock combine to yield a relatively small $(105 \mathrm{~m})$ stratigraphic thickness of Cowlitz Formation strata.

The traverse begins at a ruined railroad trestle with its foundation on the banks of Rock Creek. Although the 
volcanic rock exposed in the creek bottom has been described as a conglomerate (Van Atta, 1971) its poorly distinguishable clasts are subangular, very similar to the matrix and probably represents a blocky basalt flow (aa). This blocky basalt is found downstream (about $250 \mathrm{~m}$ ) to the fault contact with the intermediate to upper sand of the Cowlitz Formation. Above this contact, in a road cut less than ten meters above the level of the creek, the clean, very light tan arkosic sands of the "Clark and Wilson" informal member of the Cowlitz Formation outcrop. The sand at the contact, however, is fine grained, medium grey, micaceous, and somewhat "greasy" with clay. This sandstone is very friable and is found in well defined beds $(1 \mathrm{~m})$. It becomes softer, less consolidated, and lighter in color for 140 meters downstream. One concretionary shelf $(2 \mathrm{~m})$ of massive micaceous sandstone intervenes at sixty-five meters from the contact. At one hundred fifty three meters downstream, the sandstone again becomes medium grey, clay-rich and well indurated. Plant fragments and lignite layers are incorporated in this material. A very coarse grained lithic sandstone appears at 180 meters. This is replaced by finely laminated micaceous, carbonaceous sandstone which is further characterized by ovoid $(10 \mathrm{~cm})$ concretions, and intense bioturbation downstream (downsection). 
A series of grey, micaceous, laminated, poorly consolidated foram-rich siltstones were sampled to a point $510 \mathrm{~m}$ downstream from the Tillamook Volcanics Cowlitz Formation contact. Here a high, nearly vertical $(10 \mathrm{~m})$ cliff in the stream bank reveals very planar, yet intensely burrowed thin $(2 \mathrm{~cm})$ beds of medium grained well indurated light grey sandstone. Spherical to ovoid concretions of large size $(.7 \mathrm{~m})$ appear at the base of the exposure. Arkosic, micaceous, medium sand outcrops in the stream banks for another one hundred meters where the bedded sandstone sequence is repeated by the doubling back of the course of the river. This gives way to a fairly long sequence of microfossiliferous siltstones which extends to the townsite (just a few old railway station buildings) of Keasey.

Below Keasey the siltstones give way again to medium to coarse grained arkosic sandstone beds which are frequently well indurated to concretionary. One concretionary layer is $25 \mathrm{~cm}$ thick at $1600 \mathrm{~m}$. from the Tillamook Volcanics - Cowlitz contact.

Sandstones give way to another sequence of mudstones which extend downstream to nearly the end of the traverse. This sequence was productive of Foraminifera. Samples PSUA249 through PSUA252 of this study were selected from this sequence. The sequence ends with a concretionary layer $(.3 \mathrm{~m})$ in the river bank, the 
orientation of which indicates a nearby complicating fault. This is underlain by a medium to coarse grained arkosic sandstone found just downstream of PSUA252.

New Road Slump Section

Ironically this section yielded virtually no fossils of any kind and might be considered inappropriate for a paper dealing with the biostratigraphy of the Cowlitz Formation. However, it is included here because the section offers a virtually continuous vertical road cut exposure of relatively unweathered upper Cowlitz Formation sandstone. Also the section includes the Cowlitz-Keasey contact, giving it stratigraphic control. Sedimentary structures such as soft sediment deformation, trough cross bedding and channeling are much more readily observed here in a road cut than they would be in a stream section.

The stratigraphic thickness of this section is reported here only approximately as 150 meters. This lack of confidence is due to the close proximity of this section to the Rocky Point Fault (fig. 12) and because of local landsliding activity. The traverse is 1350 meters long (fig. 11), following a newly cut Longview Fibre co. logging road. The banks of the roadcut are virtually always linked at their bases, offering nearly continuous exposure of bedrock. At the eastern end of the traverse, 


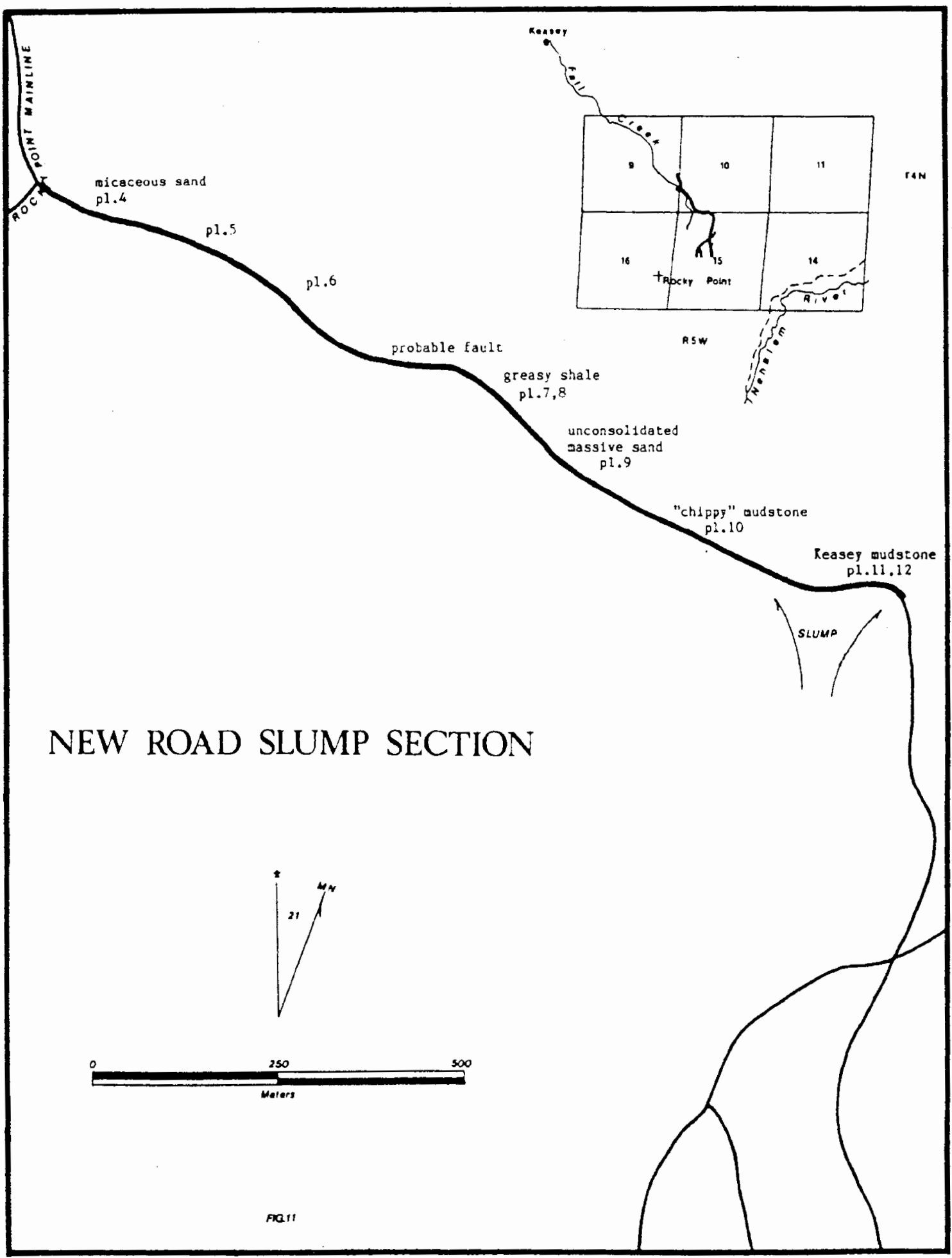




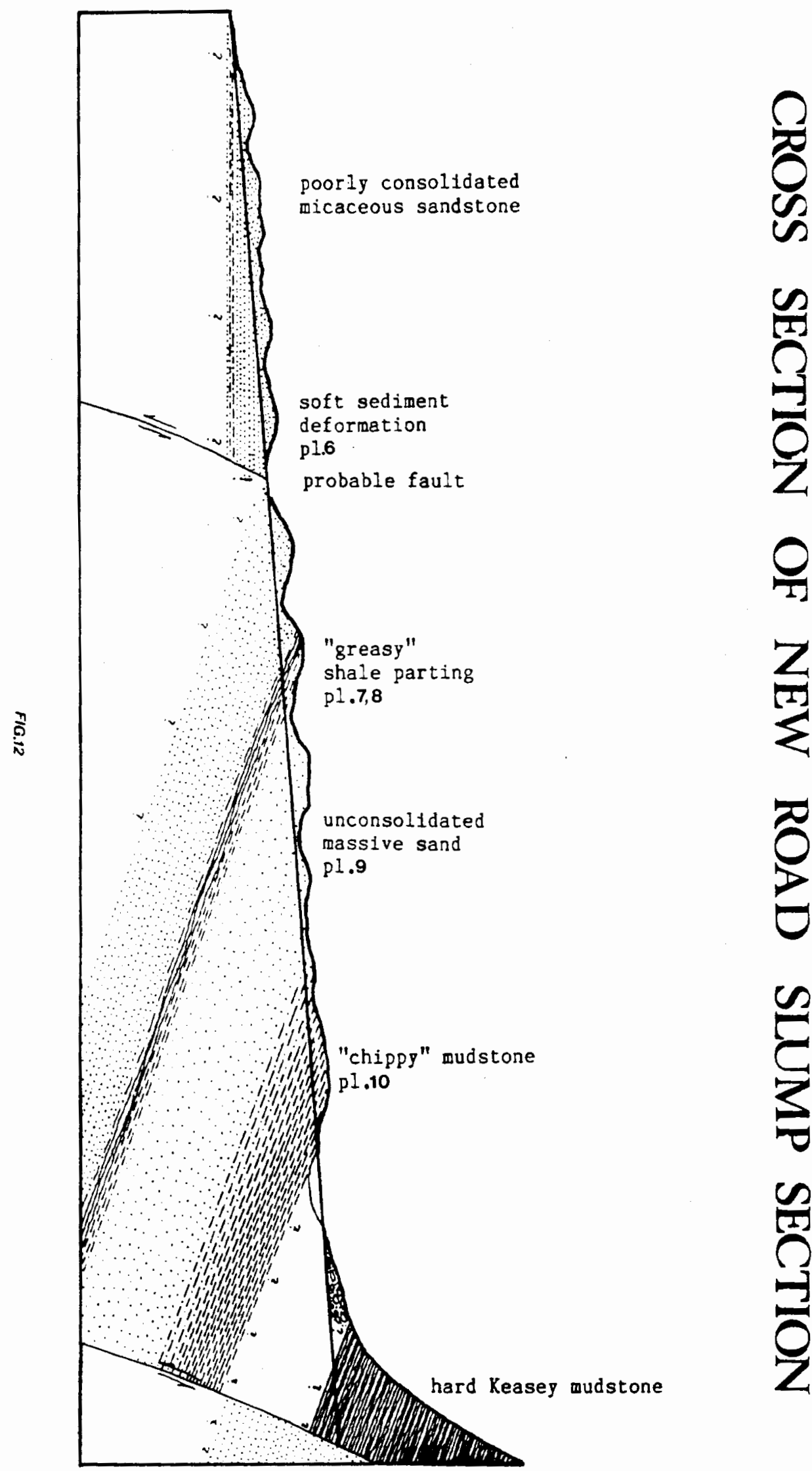


on the southyes side of the road, a very large slump exposure of the lomer keasey Formation occurs. Removal of most of the slump debris at the toe of the slide has further inproved the excellent exposure here.

The traverse begins at the "t" intersection of rocky point dainline Rod where it intersects fall Creek (fig. 11, upper left). Stratigraphically this point is well into the thick upper sandstone informal member of the cowlitz Formation.

At the beginning of the traverse, orange weathering, micaceous, arkosic upper cowlitz sands are exposed in the first series of banks along the road. The seaments are light grey in fresin sample, and are non-indurated, apparently held together by little more than the cohesion of water and traces of clay on grain surfaces (plate 4).

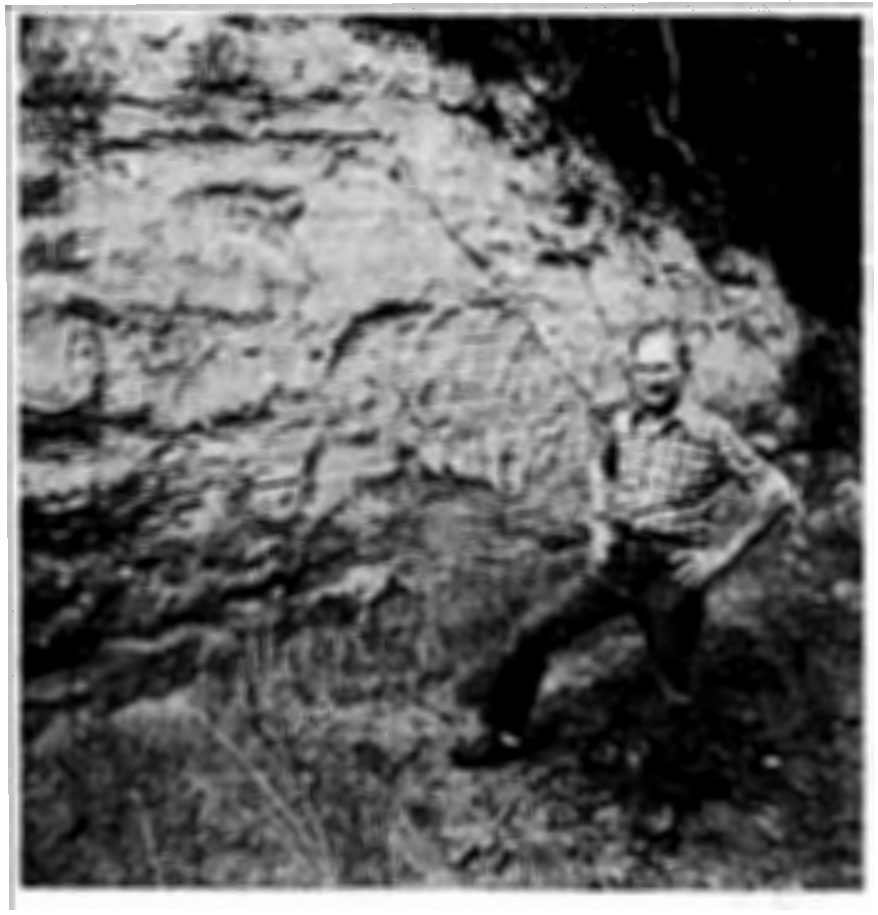


The sands have a distinct iodine or "seashore" odor. The strata here exhibit both laminar bedding as well as subdued cross stratification.

$$
\text { Proceeding uphill along the section road to the }
$$

southeast, the sands become interstratified with blue-

grey claystones. Soft sediment deformation is strikingly exhibited here (Plate 5), where density contrasts between the two sediment types as well as rapidity of deposition are indicated.

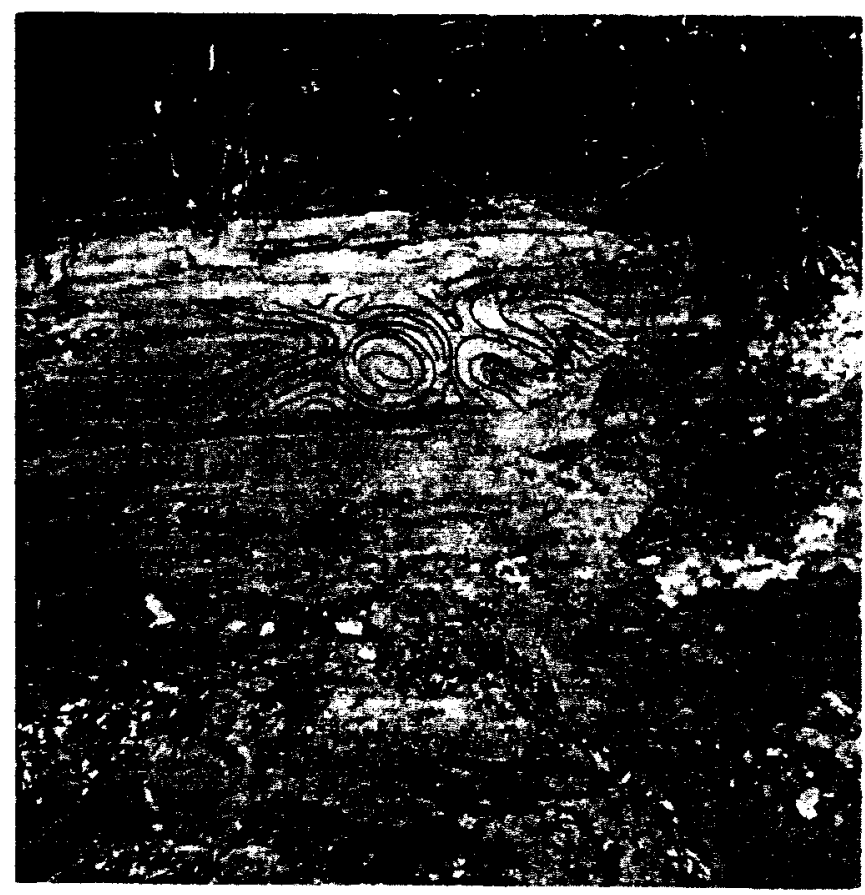

pl.5

These clay beds are further characterized by thin black laminae of Iignite. Leisegang banding is a common feature 


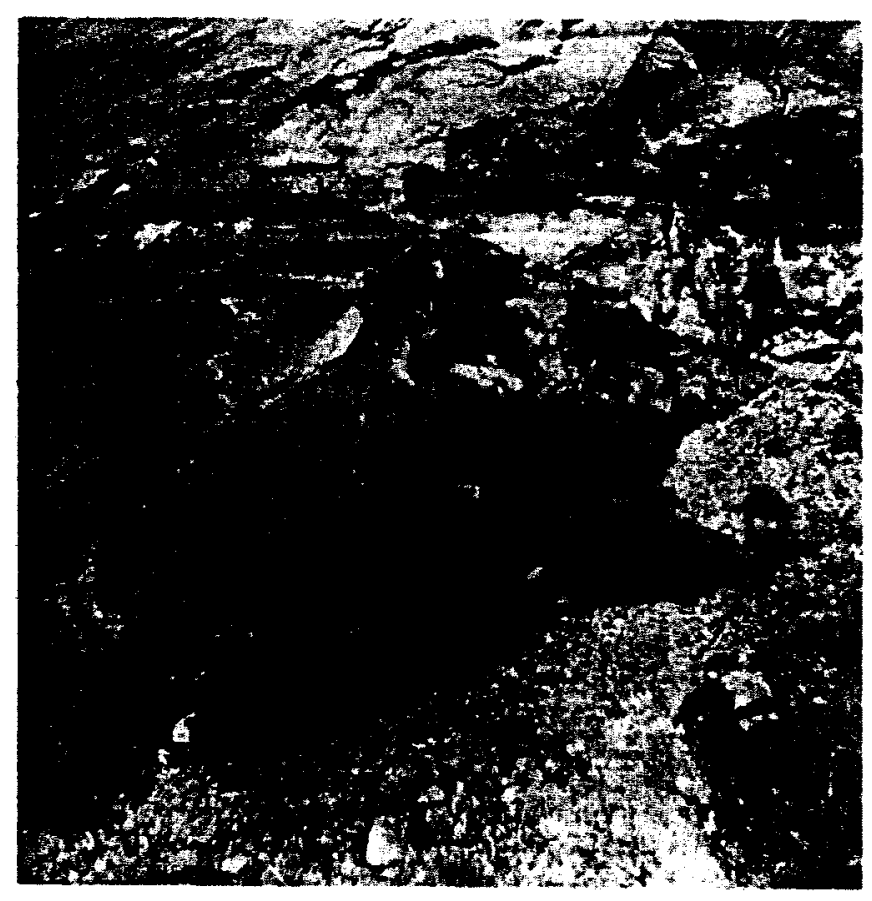

pl.6

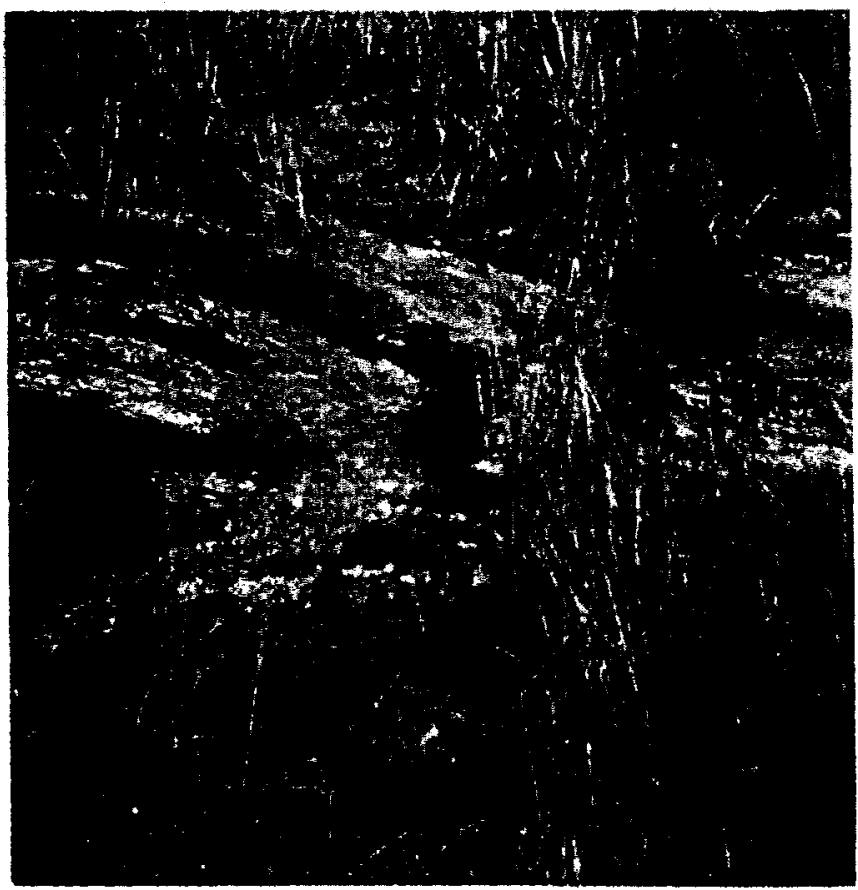


here, often contusing true bedaing orientation and sedimentary structure. Plate 6 for example, appears to indicate inverted, convex-up cross stratification, whereas the real case is that migration of limonite was controllea by small fractures in the beds. Frequent small displace ment fauts occur in this lower portion of the traverse (plate 7).

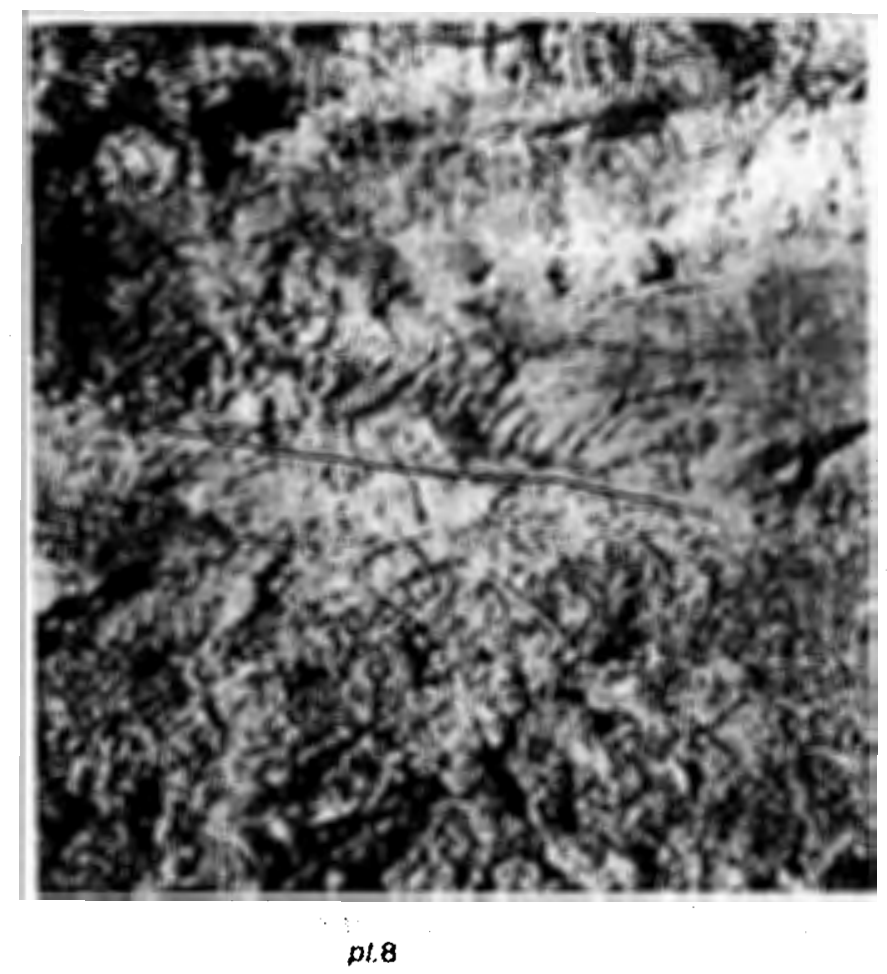

Interstratified heterolithic beds give way to a thick sequence of crossmbedded, very poorly indurated arkosic sand which is exposed in every bank to the approximate 
midpoint $(600 \mathrm{~m})$ of the traverse. Small bits of lignite are found interspersed with the quartz and feldspar grains of these beds. At this midpoint, another clay rich parting occurs between sand units. This thin claystone unit (fig. 8) incorporates what appears to be a fine grained siltstone but this may in fact be a highly weathered dark tuff. Although heavily scrutinized, these Eine-grained rocks disappointingly yielded no microfossils.

Above the claystone parting, massive, buff colored, almost completely nonindurated quartzose, micaceous, arkosic sand is exposed for a stratigraphic interval of approximately 50 meters (plate 9).

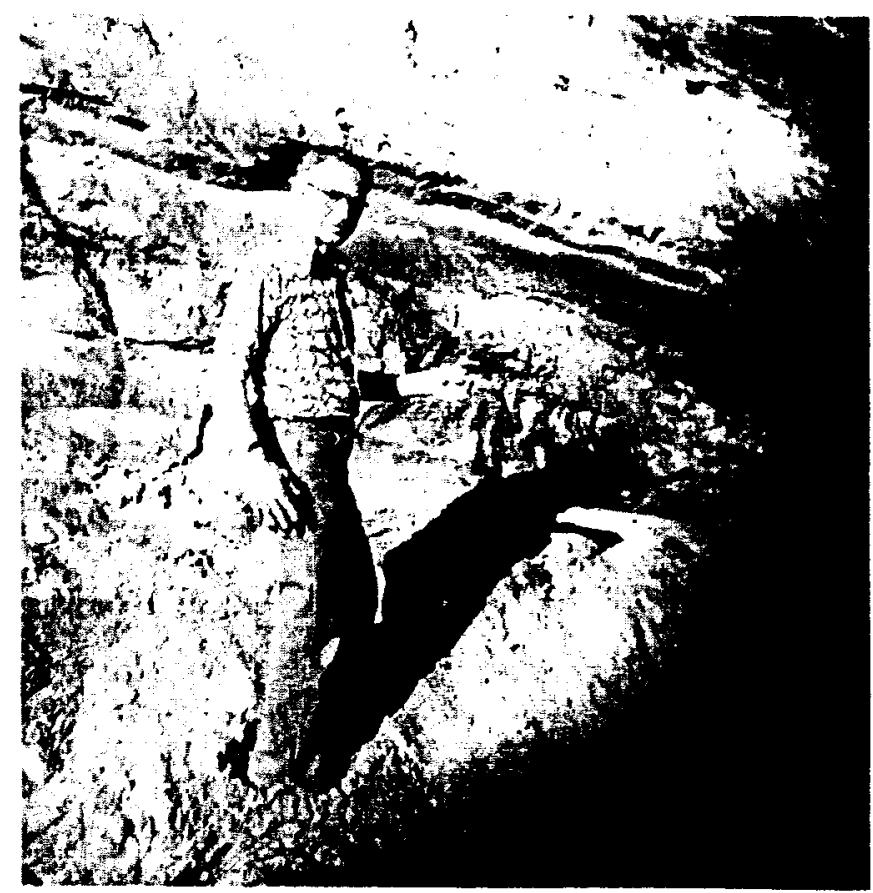

pl.9 
The well-bedaed sedinents of the lower sandstone nomber are replaced by a nearly structureless mass which is exposed in high $(10 \mathrm{~m}$.$) embankments. only very$ subtlo planar bedding is noticeable. other seaimentary structures are absent.

The final portion of the section is comprised of rajstone which arades up into the overlying keasey Fomation cound in the slump/landslide. This mudstone was vary deeply wathered to a "chippy" talus material (plate 10) in all exposures.

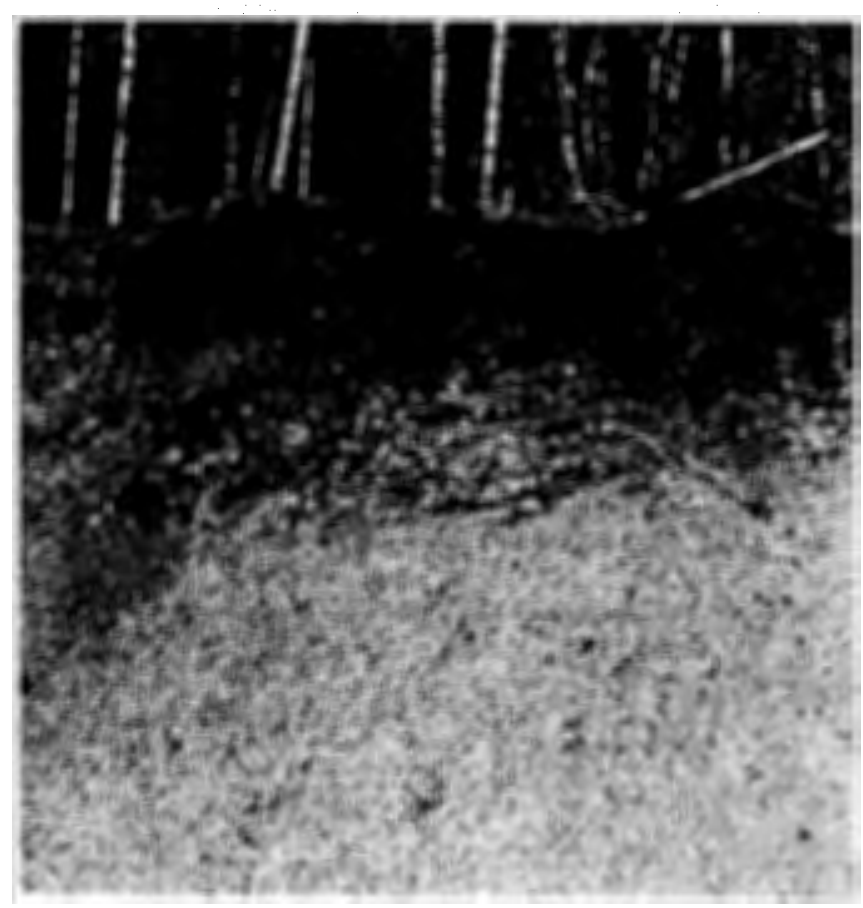

$$
p l .10
$$




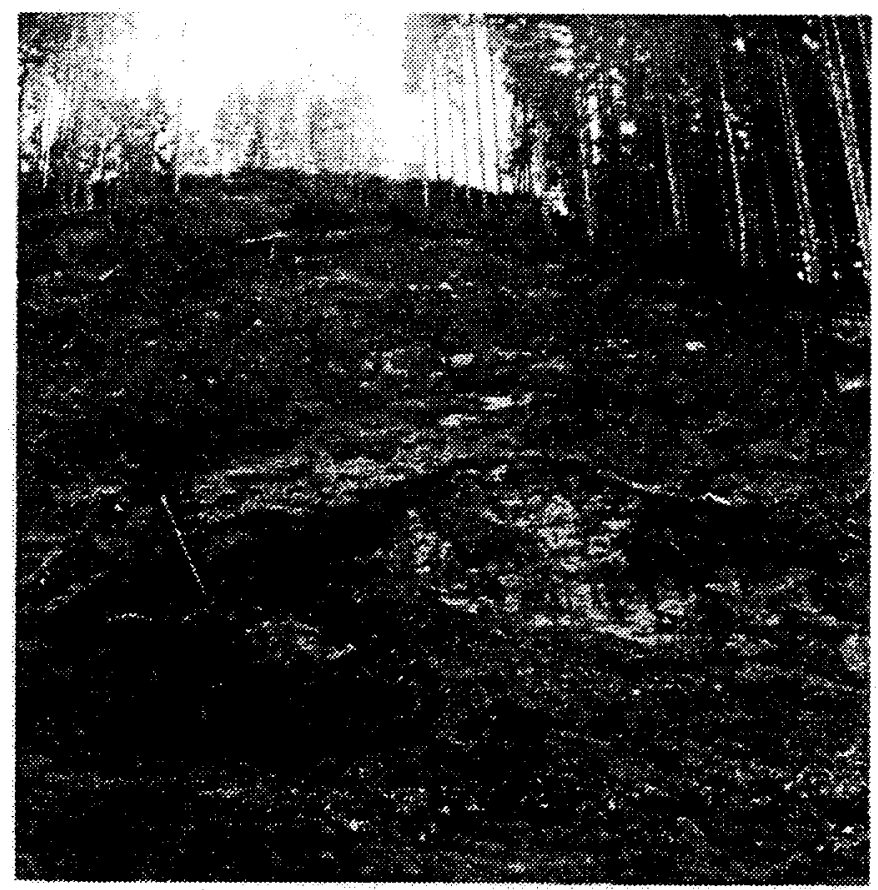

pil1

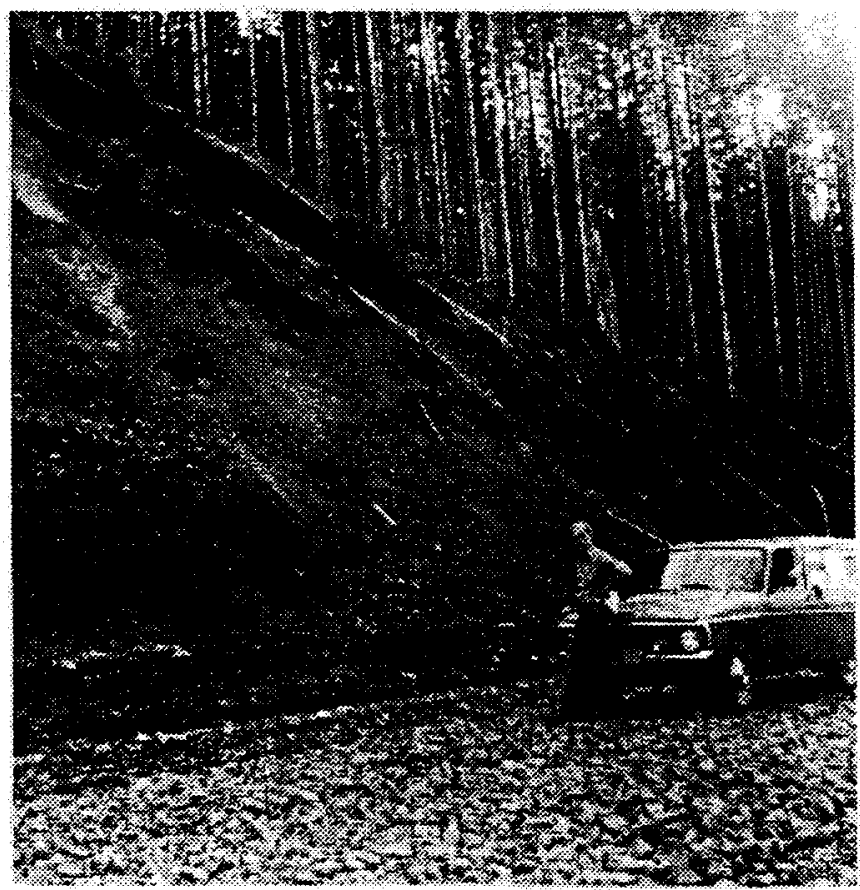

p). 12 
Again, intense sampling and excavation yielded no microfossils. The first recoverable foraminifera in thispart of the section were recovered from the mid-portion of the slump, which yielded such mid-Refugian species as Pseudoglandulin inflata (Borneman) and Melonis halkardi (Cushman).

\section{Sunset Camp section}

This traverse along the Nehalem River from its intersection with the Sunset Highway at Timber Junction to a small bridge about two kilometers upstream represents the thickest section $(493 \mathrm{~m})$ of this report (fig. 14). It is also the most reliable section. This is because no obvious large displacement faults cut it (fig. 15), nor are landslide blocks involved. Strike directions are uniform to the northeast, and dips to the southeast range between 14 and 18 degrees. Coarse basalt cobble bedload obscures much of the river bottom, but, as with the Nehalem River Section and the Rock Creek section of this report, it was usually possible to secure a sample somewhere in the river for every twenty-meter interval of the traverse.

Much of this same section (but not called by the same name) was carefully measured by Van Atta, (1971) and described in great detail. Before Van Atta, Warren and Norbisrath (1946) described the geology of the bedrock here and determined the Cowlitz-Keasey contact which 


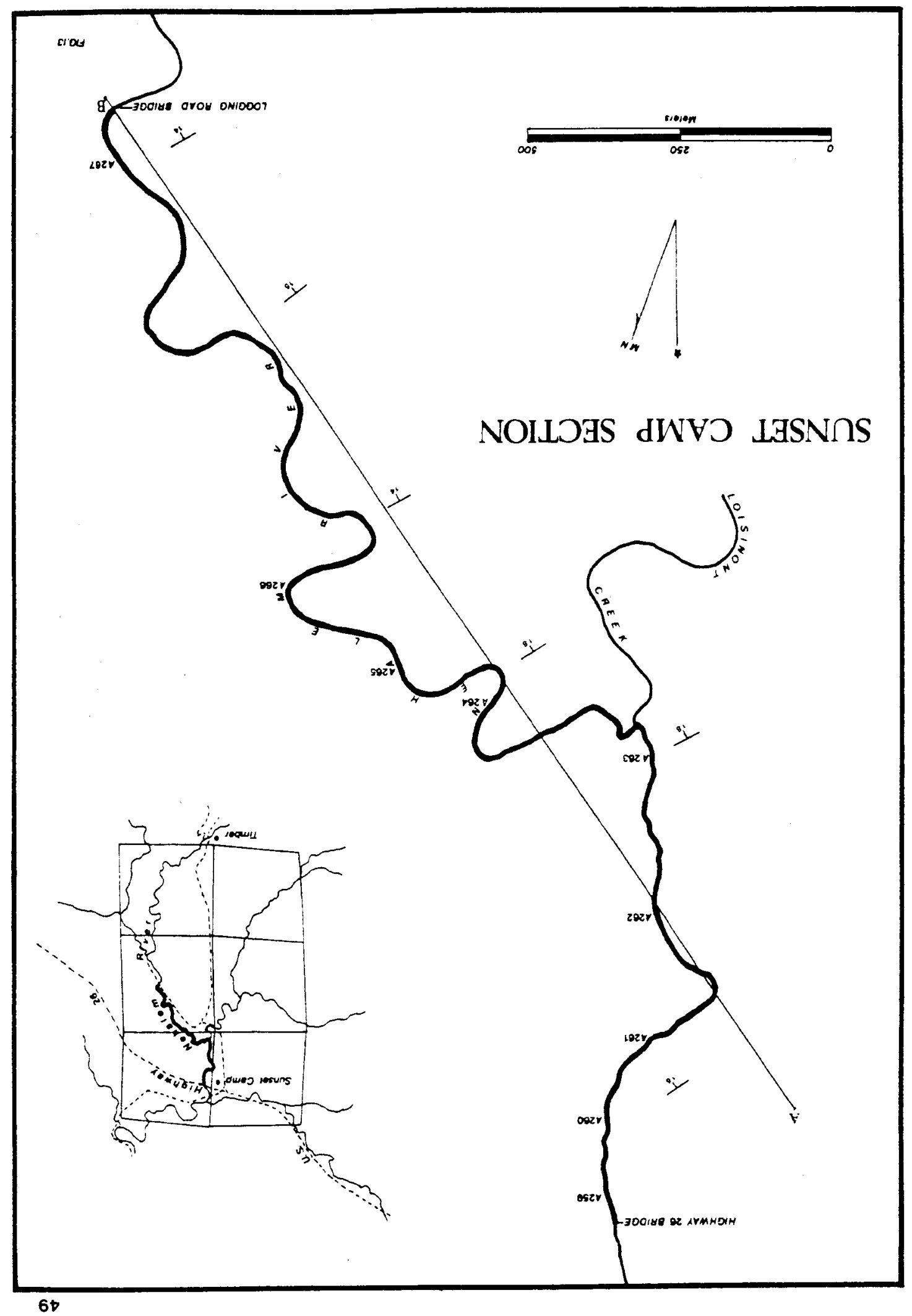




\section{SUNSET CAMP SECTION}

SEAIES STAGE ZONE FAUNULE FORMATION

KEASEY

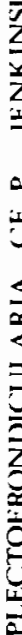

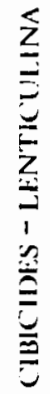

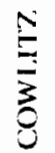

$\prod_{1}^{T}$

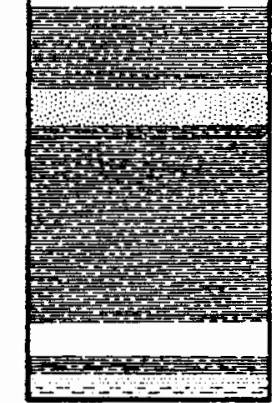

LOCALITY DESCAIPTION

A267 siltstone-massive, well indurated, tine grained non-micaceous, dark grey fresh, ret-brown wathered, microfossiliferous. siltstone-massive, pooriy indurated, fine grained, micaceous, quartzose, light grey fresh, red-brown wathered.

sandy siltstonemassive, poorly induratad, ricaceous, quartzose, medium grey fresh, yellow-brown wathered.

sandstane-massive, poorly indurated, fine grained, very micaceous light grey fresh, yellangrey weatiered.

Sltstane-massive, well indurated, coarse grained micaceous grained, micaceous, light grey fresh, yellow-grey weathered. sandstone-poorly indurated, fine grained very micaceous, quartzose, modiun grey fresh, red-brown wothered.

sandstane-elcemately poor to very well A266 indurated, micaceous

sondstane-arassive, porrly irdruted, fine grained, micaceous.

siltstonemassive, poorly indurated, tine grained, nicaceous, microfossiliferous,

A265 mollusk rich.

siltstone-massive, oderately well indurated coarse grained, micaceous, microfossilA264 iferous, mollusk rich, motiur grey fresh, yellow-brown weathered.

sandstone-massive pooriy indurated but erosion vesistent shelf-former, coarse grained, volcanic clasts, clast support, poor sorting.

siltstone-massive, poorly indurated, coarse grained, micaceous, dark grey fresh, brick

A262 red wathered, micrafossiliferous, mliusksiftstone-massive, coarse grained, micaceous Ticrofossiliferous, mollusk rich.

sandstane-massive, well indurated, coarse A261 grained, lithic angular clasts. siltstone-massive, moderately indurated, coarse grained, micaceous, dark grey fresh, A260 red-arange watherex, micrfossiliferous, mollusk rich.

A2ro

sardstane-coarse grained, lithic, calcite cemented, dark grey fresh, light grey weathered. 


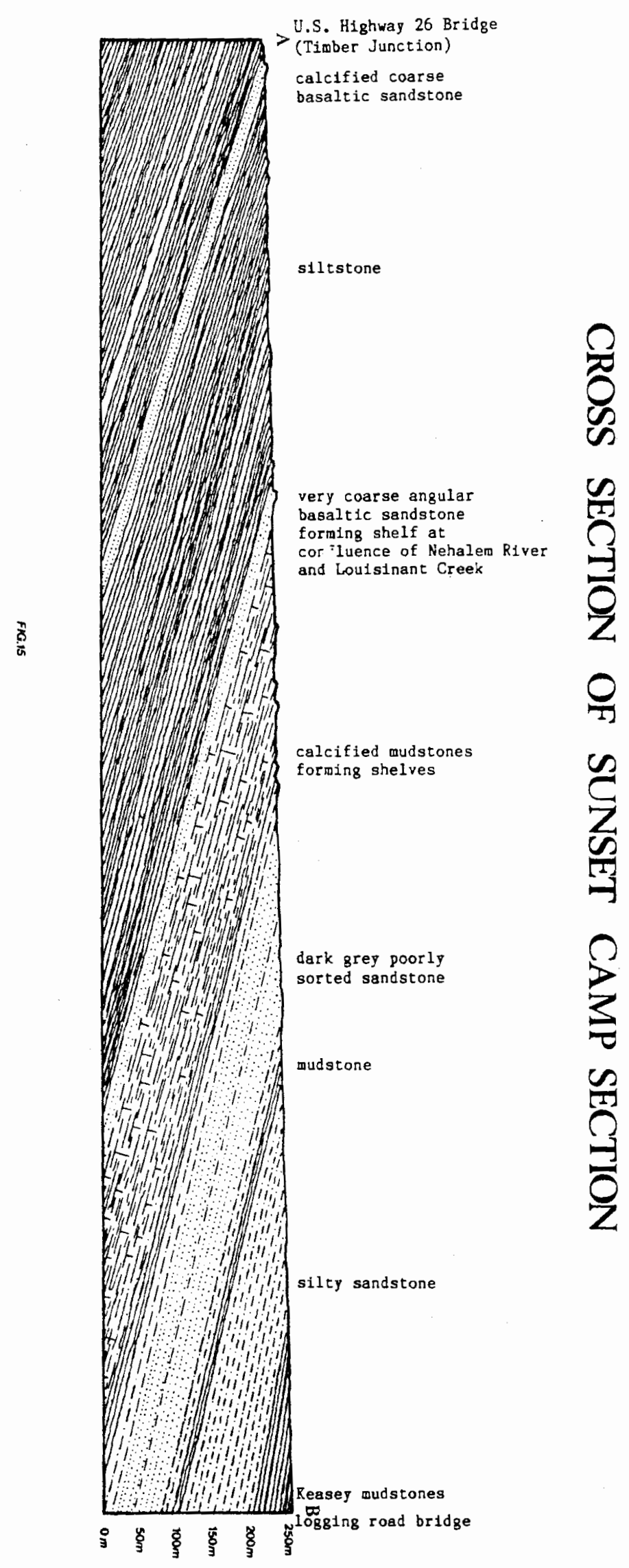


intersects the course of the river using Foraminifera as well as noting collection sites for megafossils in the stream banks. This author was aided by consideration of this earlier work.

This section has one flaw; it is probably somewhat atypical of the upper Cowlitz Formation in the upper Nehalem River vally. That is, the sandy silt and sandstone unit toward the top of the section is dark, "dirty" with ash and clay. Normally this sand unit is well sorted, mature, and appears light tan or very light gray in outcrop. Foraminifera are absent in this unit as they are in other upper sand outcrops of the Cowlitz in the study area. Medium and fine sand particles of quartz and feldspar grains predominate, and the position of the sands in the stratigraphic column is similar, but the similarity ends there. This section may represent a local facies change, possibly a less energetic environment of deposition, or one further from clean sediment sources.

The traverse began at the sunset Highway bridge (fig. 13). Here, in the stream bottom, rather massive, dark gray beds of micaceous siltstone and mudstone of the upper lower mudstone informal member of the Cowlitz Formation outcrops. Immediately to the south appears the first sandstone, a coarse grained, calcite cemented (white crystalline matrix) volcanic material which forms a strike controlled, thin $(.4 \mathrm{~m})$ shelf which 
cuts the river at nearly a right angle. Such shelves as this one were to characterize many portions of the river, the course of which is clearly strike controlled (fig. 13). Strike control is most noticeable in the northeastsouthwest lineations near the confluence of Lousinont Creek and the Nehalem River approximately one kilometer upstream from the Sunset Highway bridge.

Beyond the sandstone shelf a long sequence of wellbedded microfossiliferous and mollusk rich siltstone outcrops for a traverse distance of about two-thirds of a kilometer to the confluence of the Nehalem River and Louisinont Creek (fig. 13). The stratigraphic thickness represented here is one hundred twenty five meters from the Sunset HIghway. This siltstone is dark gray in fresh hand sample, rusty brown in weathered sample. It is medium grained and quite micaceous. The unit is relieved by just one thin $(3 \mathrm{~m})$ shelf, forming well indurated sandstone which appears at sample site PSUA 262 on (fig. 13), about one half kilometer from the bridge, and $96 \mathrm{~m}$ stratigraphically from the stratigraphic columns base (fig. 14). This sandstone is poorly sorted, massive, very coarse grained, volcanic, angular, and olive green in both fresh and weathered samples. A short series $2 \mathrm{~m}$ of resistant sandstone ledges mark the end of this sequence at the confluence of Louisinont creek and the Nehalem River. 
The next sequence is also of siltstones which outcrops to the approximate position of PSUA266 where the river follows a series of erosion resistent sandstone and siltstone shelves, which control the course of the stream for several hundred meters. These siltstones are typically massive, poorly indurated to well indurated, micaceous, dark grey in Eresh sample and reddish-brown in weathered sample. These sediments offer many mollusk fossils as well as foraminifera and are cited by Warren and Norbisrath (1946) as exceptionally good megafossil collection sites. Clast size increases and foraminiferal abundance diminishes upsection. This portion of the traverse represents a stratigraphic thickness of 134 meters.

In the next portion of the section, gray siltstones become increasingly sandier, giving way to the gray "dirty" micaceous, arkosic sands of the upper sandstone informal member of the Cowlitz. As mentioned above this probably is an atypical, hardly recognizable equivalent of the "Clark and Wilson" sandstone. The sandy silts and Eine grained sands, however, do not include the calcified, resistant material of the subjacent sections. These upper sandy deposits are either poorly or very poorly indurated or even unconsolidated as in "Clark and Wilson" sediments. The color changes in these upper section deposits to a significantly lighter gray 
reflecting the higher proportion of quartz and feldspar grains. As mentioned above, Foraminifera are absent, as in the "Clark and Wilson" sand of other Cowlitz Formation sections.

The upper segment of the Cowlitz Formation of this section comprises 96 meters of the stratigraphic column (fig. 14). Although samples classify as siltstones (Van Atta, 1971), a variety of lithologies exist, including some finer grained claystones and sandy silt as well as sandstone beds. These beds are also largely barren of fossils. In color these rocks are light grey in fresh hand sample and weather yellow-gray.

A detailed discussion of the Cowlitz-Keasey contact at the top of this last portion of the section is included in the biostratigraphy section of this paper.

\section{Keasey Formation}

The Keasey Formation was not the subject of this study, but the lowermost part of it was included in measured section including the sunset Camp Section and New Road Slump Section in order to establish their stratigraphic position. This formation comprises about 700 meters (Warren and Norbisrath 1946) of tuffaceous shale and mudstone containing many megafossils and a large assortment of deep-water, largely Refugian, Foraminifera. 
In hand sample the sediments of the basal Keasey closely resemble those of the upper Cowlitz mudstones both being gray, fine grained, poorly stratified rocks. On close examination, however, the distinct lack of mica in the Keasey Formation sediments marks the Cowlitz Keasey contact. In the sunset Camp section of this report, coarser siltstone with much mica and arkosic, quartzose sand of the uppermost Cowlitz Formation gives way to fine, slightly darker-grained material with little mica. Lithic fragments occur in both members but are strikingly more abundant in the Keasey.

Kadri, Beeson, and Van Atta, (1983) used geochemical analyses to indicate a change of provenance of sediments from Cowlitz to Keasey time. They found that Cowlitz rocks were enriched in mica, feldspar, thorium and potassium, while Keasey rocks contained relatively less of these constituents as well as more volcanic rock fragments. A plutonic/metamorphic provenance of the Cowlitz Formation and mixed volcanic/continental provenance for rocks of the Keasey Formation are indicated. 


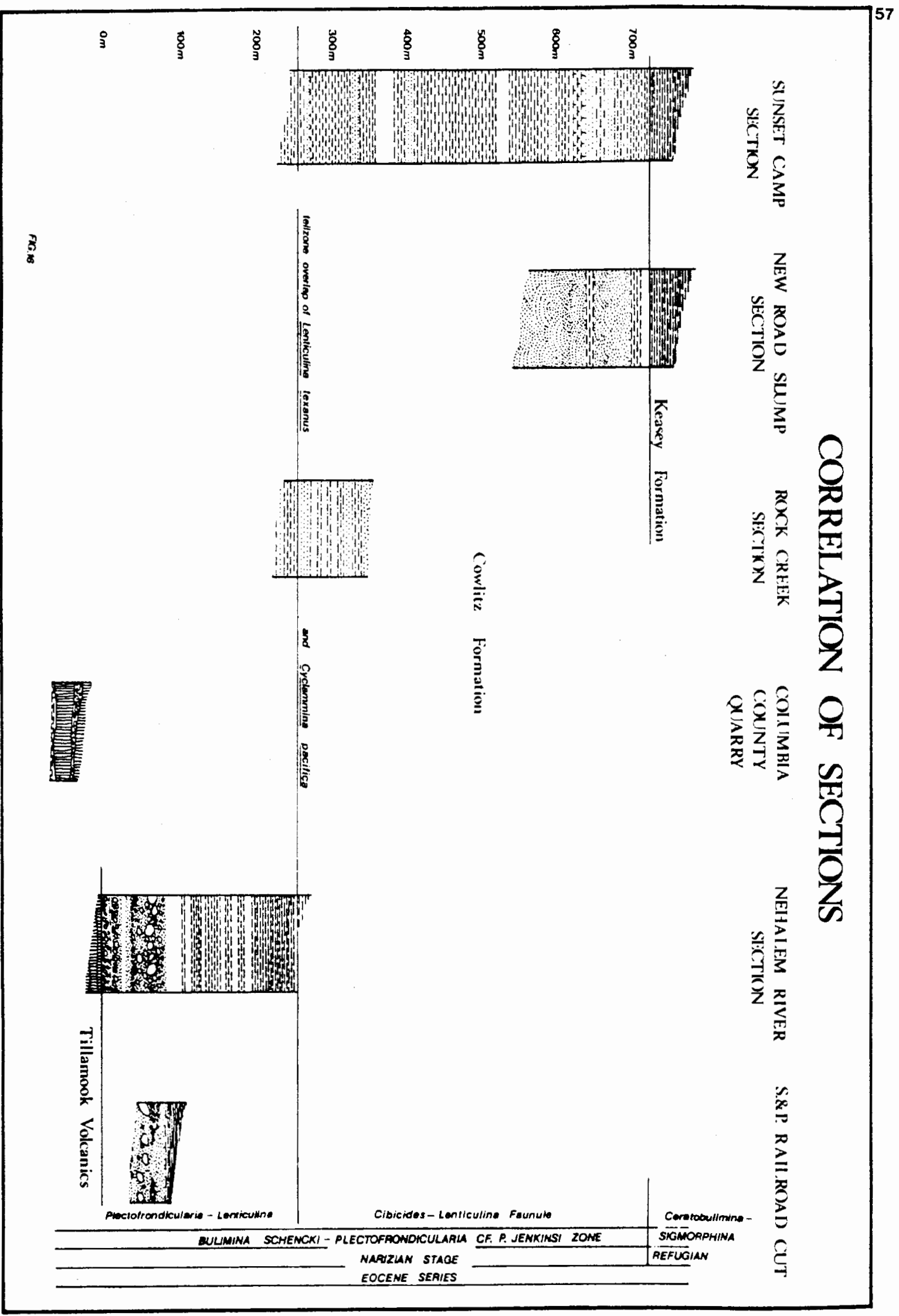




\section{CHAPTER I I I}

\section{PALEONTOLOGY}

\section{The Foraminifera}

The Cowlitz Formation in the study area exhibited a fairly limited number of species of Foraminifera. Fortyfour species were identified. These constitute 33 genera and 14 families. The most numerically prominent families include: Rhizamminidae represented by Bathysiphon; Lagenidae, represented by Lenticulina, Dentalina, Lagena, and Marginulina; Heterohelicidae, represented by plectoErondicularia; Buliminidae, represented by Bulimina, Bolivina, and Trifarina; Rotaliidae, represented by Gyroidina and Eponides; Cassidulinidae, represented by Globocassidulina; and Anomalinidae, represented by Cibides.

\section{Other Fossils}

Although the Foraminifera were of primary interest in this paper, a number of larger fossils including those of gastropods, pelecypods, decapods, brachiopods, and fish teeth were collected in several localities. The most productive locality was the Columbia county Quarry, 


\section{CHECKLIST OF SPECIES}

FORAMINIFERA

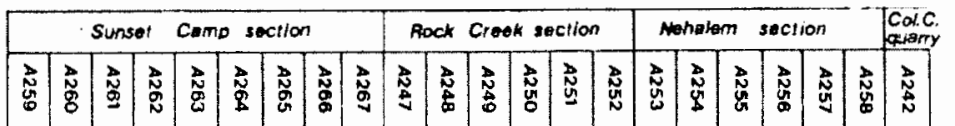

Alicmorphisa cf.

Anerstone of Rou 1048 kisrer

Mmodiscus combsi Lexk

Sxthysifings excenico usingan \& C.D. Wanta

Boldia axtge:

(Custrent \& Scherk:

Bolivina basicenta.

Gistman stowe

bolivin kleingell Beck

Phlimina stescis Bok

Ceratobulinina nashburre: (instrean \& solenck

Cibicides ip.

Cibicides beileyi Berk

$\frac{\text { Cibicites rat landi }}{\text { pert }}$

$\frac{\text { Cvclantine pacifica }}{\text { Lew }}$

Donkalina dysobany

Dentalina conmons d'Orbign:

Fsierchli

Eproides mexicana (Cusines)

Globocossidulira globos (kintken)

Globobulinira so.

Globobulimina Racifica Cisthin

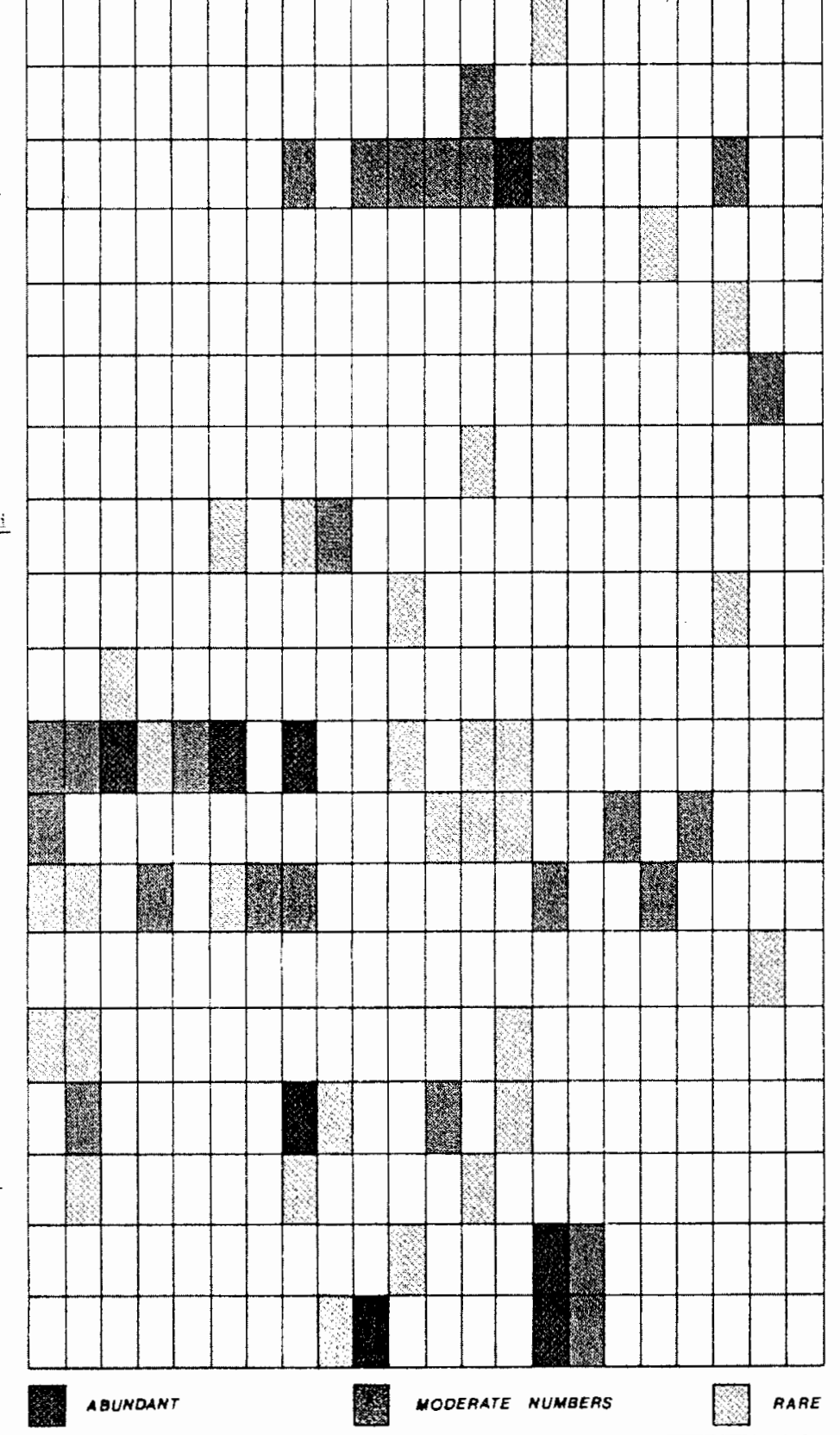




\section{CHECKLIST OF SPECIES}

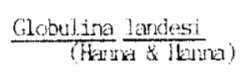

Gutuline irreguaris (d'Orbigny)

Gooidine conton

(Cus rin \& Shemk)

Grroidina orbicularis

vat. planata

Cust narn

Latera $s$

Lenticulina Sp,

Ienticulina welchi Church

Lenticulina isonktus (d'orbigry)

Lenticulina texanus

(Gishman \& Applin)

thamling $\mathrm{SD}$.

thessilina s.

Hxigsinia s.

Plectofrunticularia packirdi - Gestum

Pseudoglankthe ?he so.

Peendoglandulina evata Ostomer?

Psendohastigerina micris (Cole)

Pseudonodosaria wara

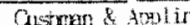

Psetdonatosia conica (Cenefkren)

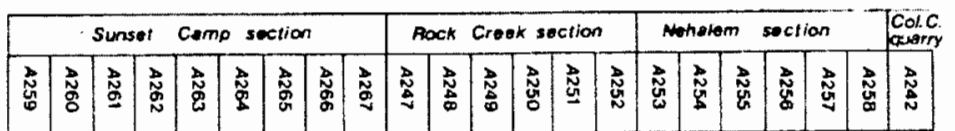

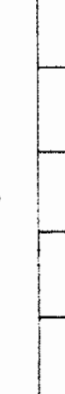
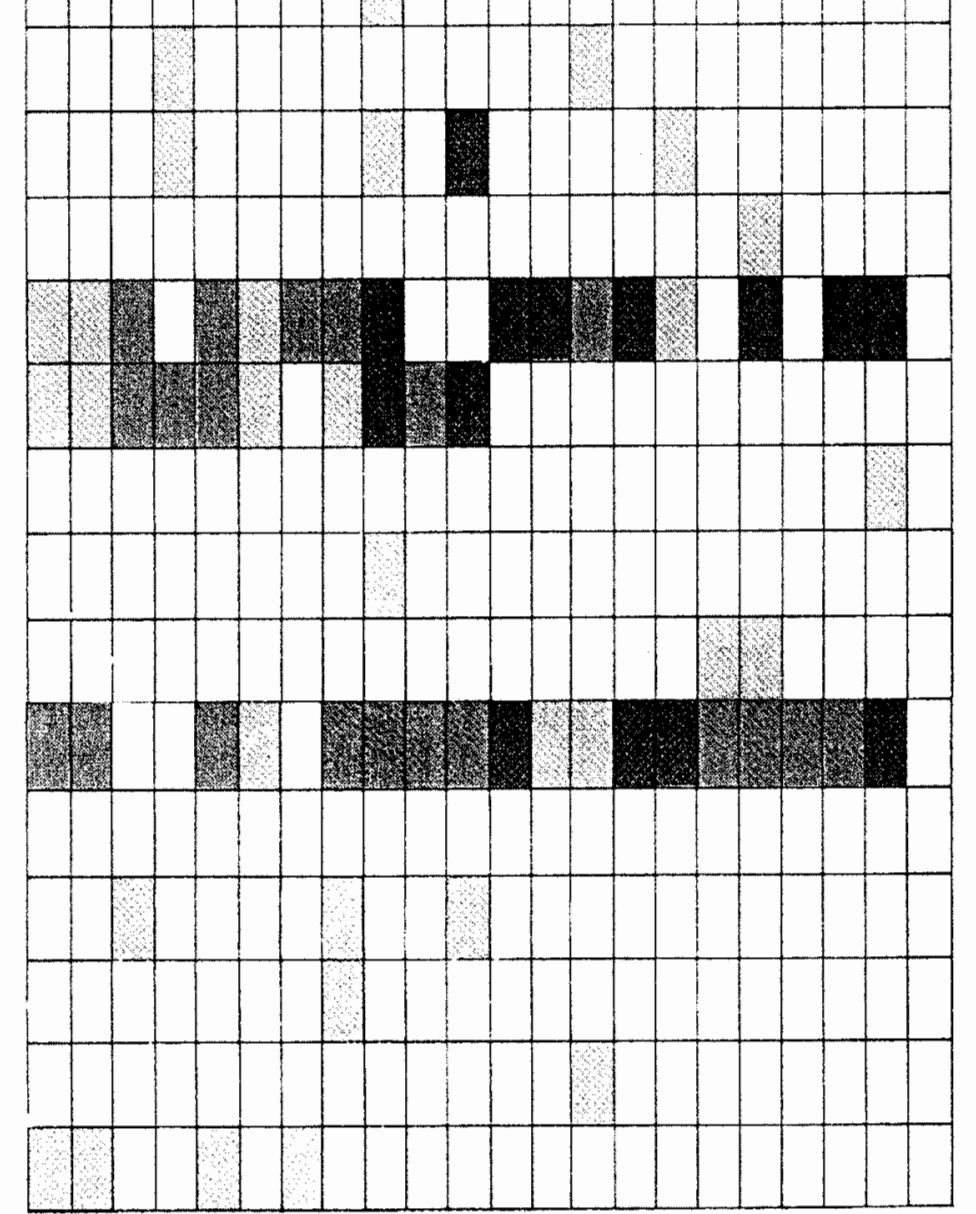


\section{CHECKLIST OF SPECIES}

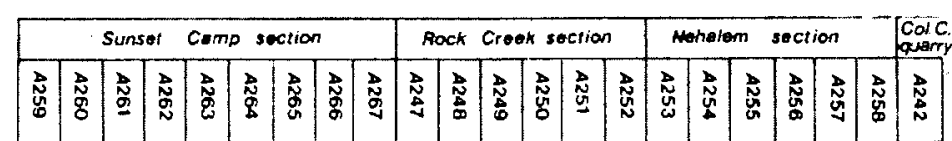

Quinguiliculina s.

Qunquiloculine imperialis Hanna \& Henta

Saracenaria hantkesi Oustum

Srilostometio s.

$\frac{\text { Iriforima hami }}{\text { Beck }}$

thigcrina sp.

Vegimuling SIs.

Vagirulopsis sumpitersi (Janne \& Mannki)

Virculinas s:

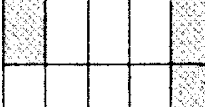




\section{CHECKLIST OF SPECIES}

\begin{tabular}{|c|c|c|c|c|c|c|c|c|c|c|c|c|c|c|c|c|c|c|c|}
\hline \multicolumn{8}{|c|}{ Sumser Camp soction } & \multicolumn{6}{|c|}{ Rock Creek soction } & \multicolumn{5}{|c|}{ Montiom section } & $\begin{array}{ll}\text { colc } \\
\text { aer }\end{array}$ \\
\hline & & 悹 & & & 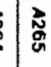 & & & & & & & & & & & & & 胥 & \\
\hline
\end{tabular}

Exiliat dickensoni weaver

Glycimerus sㅘ.

Mylilus sp.

Nekexis

wasingtoniant (weaver)

Ostrez joriensis (Gebs)

$\frac{\text { Ostrea grisiessis? }}{\text { (Efinger) }}$

$\frac{\text { Pitar califomiara }}{(\text { Conrad })}$

Polinices sp.

Polinices $\mathrm{sp}$.

Polinices nucitormis

$$
\text { (Gab) }
$$

Spicula bisculptata (Anderson \& Hama)

Spisula parkardi

Tellina corlitzensis (Weaver)

Turricula conliugensis (weater)

Volsella so.

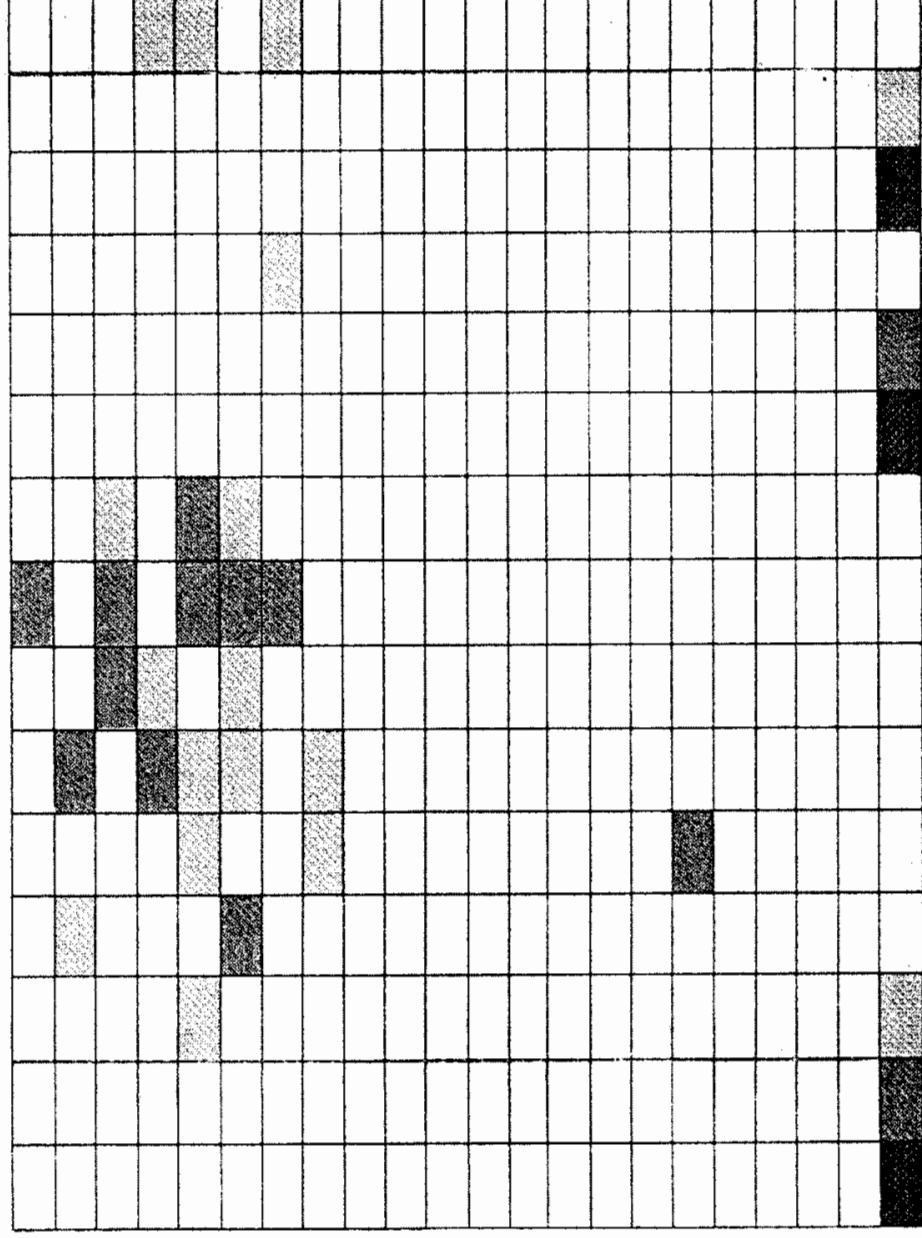

BRACHIOPODA

Terebratalia sp. A

Terebratalia $\leq$.

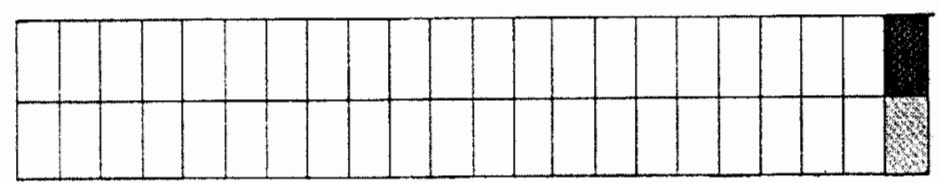


(plates 1, 2), which yielded the greatest number of mollusks. The sunset Camp section also yielded gastropods, decapods, scaphopods and pelecypods. Another notable collection site was that of the $S \& P$ Railroad cut. Here several species of terrestrial plant species were discovered in great profusion in tuffaceous, calcareous light tan siltstone which probably represents a tuff bed within the uppermost Tillamook Volcanics. 
CHAPTER IV

PALEOECOLOGY

Introduction

The climate of western Oregon during the late Eocene was subtropical with a probable mean annual temperature of $68^{\circ} \mathrm{F}$ (Chaney, 1933). This is based largely on a diag-nostic subtropical flora which is restricted to the sub-tropics of the western Hemisphere (Detling, 1968). This flora reflected a warming trend throughout the Eocene epoch. Benthonic foraminiferal species assemblages in the measured sections of this report do not directly indicate this warm environment, however, because the number of species represented is relatively small while numbers of individuals are often high. This indicated a cool or temperate environment. However, bottom temperatures were probably a function of depth in a stratified Eocene sea, rather than of surface conditions.

In this report diagnostic species in faunal assemblages have been used to determine features of the environment of deposition. These features, although potentially numerous, will be limited here to water depth, temperature, and to a lesser extent, circulation. Refer- 
ences used extensively in these interpretations were Smith (1964), and Bandy and Arnal (1960).

Plectofrondicularia - Lenticulina Faunule

The lower faunule recognizable in the Cowlitz Formation of the study area is found in the Nehalem River section and the lowermost portions of the Rock Creek and sunset Camp Sections of this report. This faunule encompasses the entire range of Cyclammina pacifica Beck in the several measured sections of this report. This faunule also includes most of the local range (teilzone) of Gyroidina condoni (Cushman \& Scenck).

The presence of Cyclammina pacifica Beck as well as other forms in this faunule is indicative of deep water. Cyclammina favors bathyal depths and cold temperatures (Delise (1967, p. 15). Gyroidina condoni, (Cushman and Schenck) likewise favors bathyal, cold water. Even more telling is the abundance, in every sample, of plectofrondicularia packardi Cushman and Schenck. Plectofrondicularia is restricted exclusively to bathyal depths and cold waters.

Several other species of microfossils which are less definitive with regard to depth also occur in this faunule. The lagenids Lenticulina inornatus (d'Orbigny), L. welchi Church, and L. texanus (Cushman and Applin) occur regularly, especially toward the top of the unit. The 
occurrence of these forms suggests that deposition occurred no lower than upper bathyal depths.

Cibides $=\underline{\text { Lenticulina Faunule }}$

The Cibides Lenticulina faunule described here represents an outer neritic environment of deposition. The abundant presence of Plectofrondicularia packardi Cushman argues for deep water. Gyroidina species, however, drop out in this faunule, only to reappear in the basal Keasey Formation. Quinqueloculina sp. become increasingly present in this faunule, indicating a possible shallowing trend. Cibides species, most notably C. natlandi Beck, become increasingly abundant in this faunule. The abrupt upper limit to the range of $C$. natlandi Beck probably marks the uppermost limit of the faunule.

Many species of this faunule indicate cold water. Pseudonodosaria ovata, Cushman and Applin, as well as P. conica (Neugboren) are strong indicators of cold water. Bathysiphon eocenica Cushman and G. P. Hanna, as well as Globocassidulina globosa (Hantken) also indicate cold bottom temperatures. The presence of the warm water genus Quinqueloculina probably indicates a stratified condition; near surface waters were significantly warmer than those below a well defined thermocline. quinqueloculina individuals died and worked their way 
downslope to mix with cold water forms (thanatocoenosis).

Salinities were normal in this faunule.

Environment of Deposition of the Upper Cowlitz Sands

A fairly wide variety of opinion exists among recent workers concerning the environment of deposition of the Cowlitz Formation in Oregon. Bruer (1980) postulated a bathyal "deep channel" model for the Cowlitz Formation upper sands. Myers (1984) speculated that these sands were deposited at outer neritic depths beyond a short shelf and delta. In the Myers model, delta sands were fed by gravity flow down the delta face and basin slope into deep water. Jackson (1983), Timmons (1981), and many others shared the view that the upper Cowlitz sands were deposited in a wave-dominated inner neritic to beach environment. Alger (1984) suggested that the Cowlitz sands were deltaic.

What lines of evidence support these various models? What, if anything, can be concluded from a discussion of them?

Wesley Bruer in cooperation with Richhold Energy Co. is credited with the discovery of the Mist gas field a few miles north of the study area. He speculated that the gasbearing upper Cowlitz sands were deposited at bathyal 
depths by strong traction currents. Figure 18, the "deep channel model" roughly illustrates his concept.

Bruer noted that foraminiferal assemblages found stratigraphically immediately above and below the upper sands were representative of upper bathyal to outer neritic depths. He also noted that wells drilled to the west of the Mist field showed an abrupt loss of clean sands along a line approximating the Clatsop County - Washington county boundary. In wells drilled immediately to the East of Mist, the clean sands were replaced by coal deposits and mudstones containing distinctly inner neritic foraminiferal assemblages. These lines of evidence led him to conclude that the thick sands from which the Mist field produced were deposited in a well-defined, steepsided, deep channel analogous to the modern straits of Juan de Fuca. Bruer noted that traction loads on the bottom of the straits can include even coarse gravels, as well as well sorted sand deposits.

Data from wells to the south of Mist in the Willamette Valley showed that relatively clean arkosic sand deposits included in the Cowlitz Formation and its southerly equivalent, the spencer Formation, showed a gradual eastwest widening and an apparently directly related reduction in porosity, and a thinning of the deposit. This Bruer interpreted to be a widening of the channel which he had postulated. In this broader channel, bottom currents 
DEEP CHANNEL MODEL

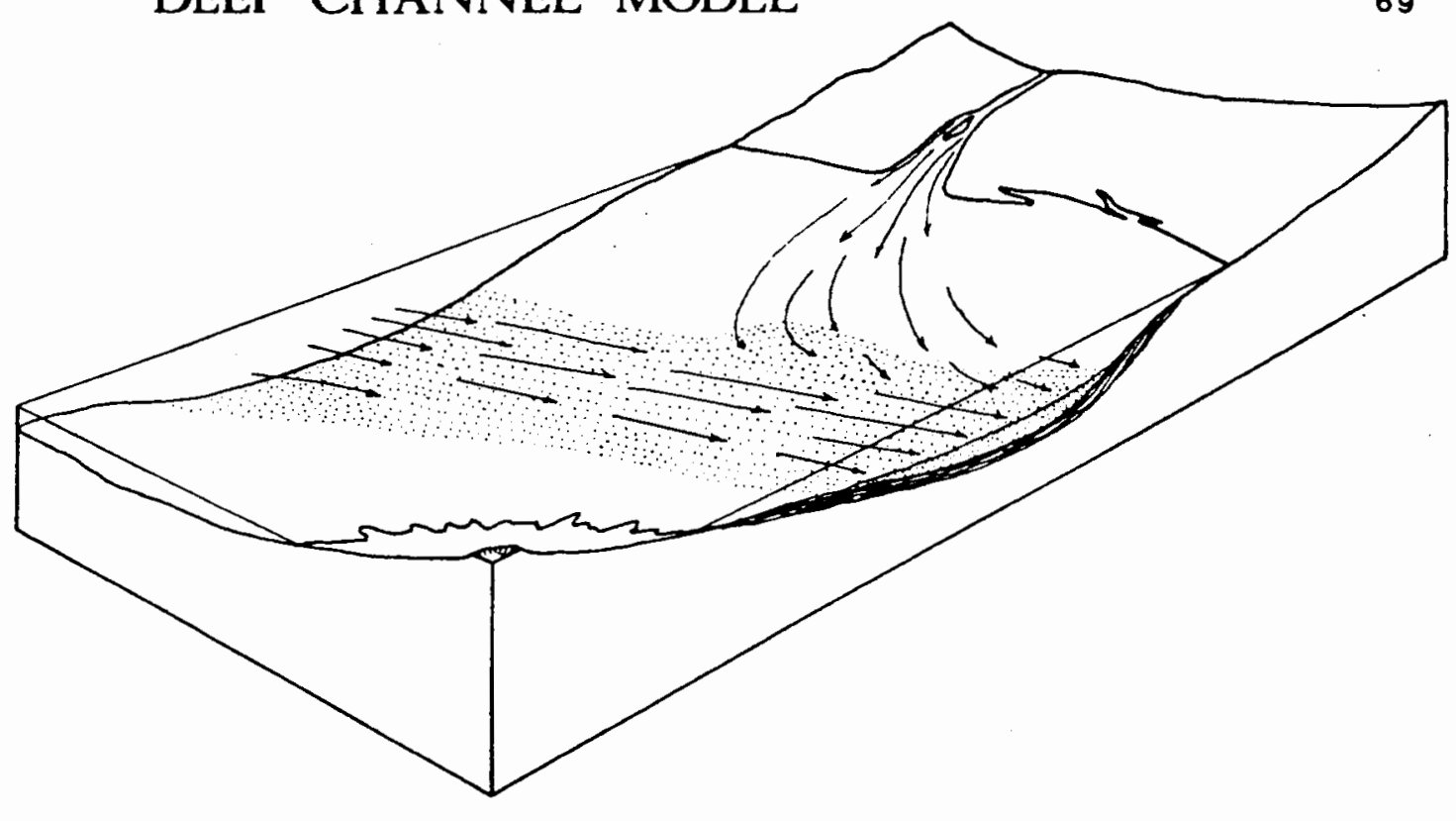

no

DELTA FACE MODEL

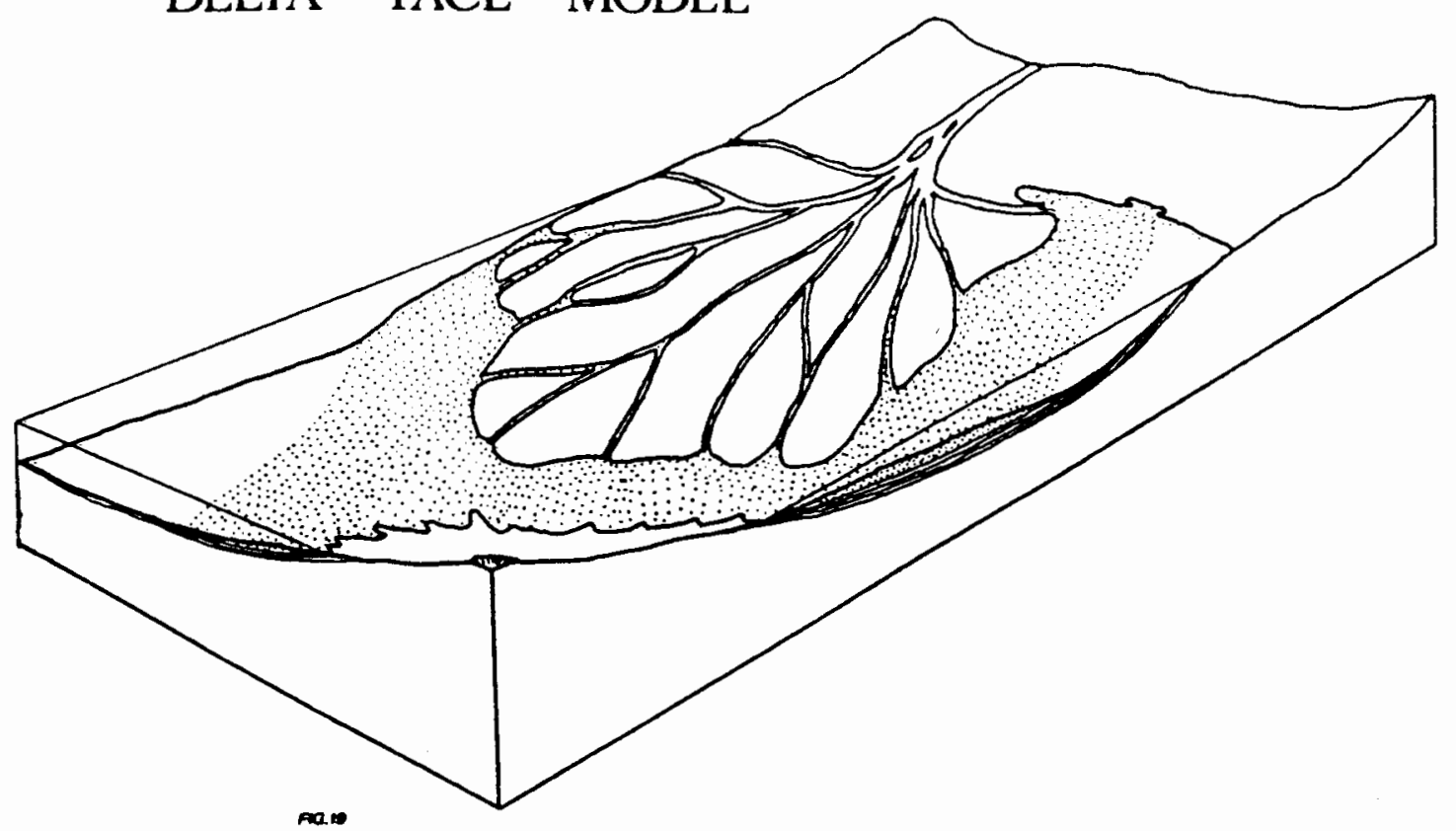




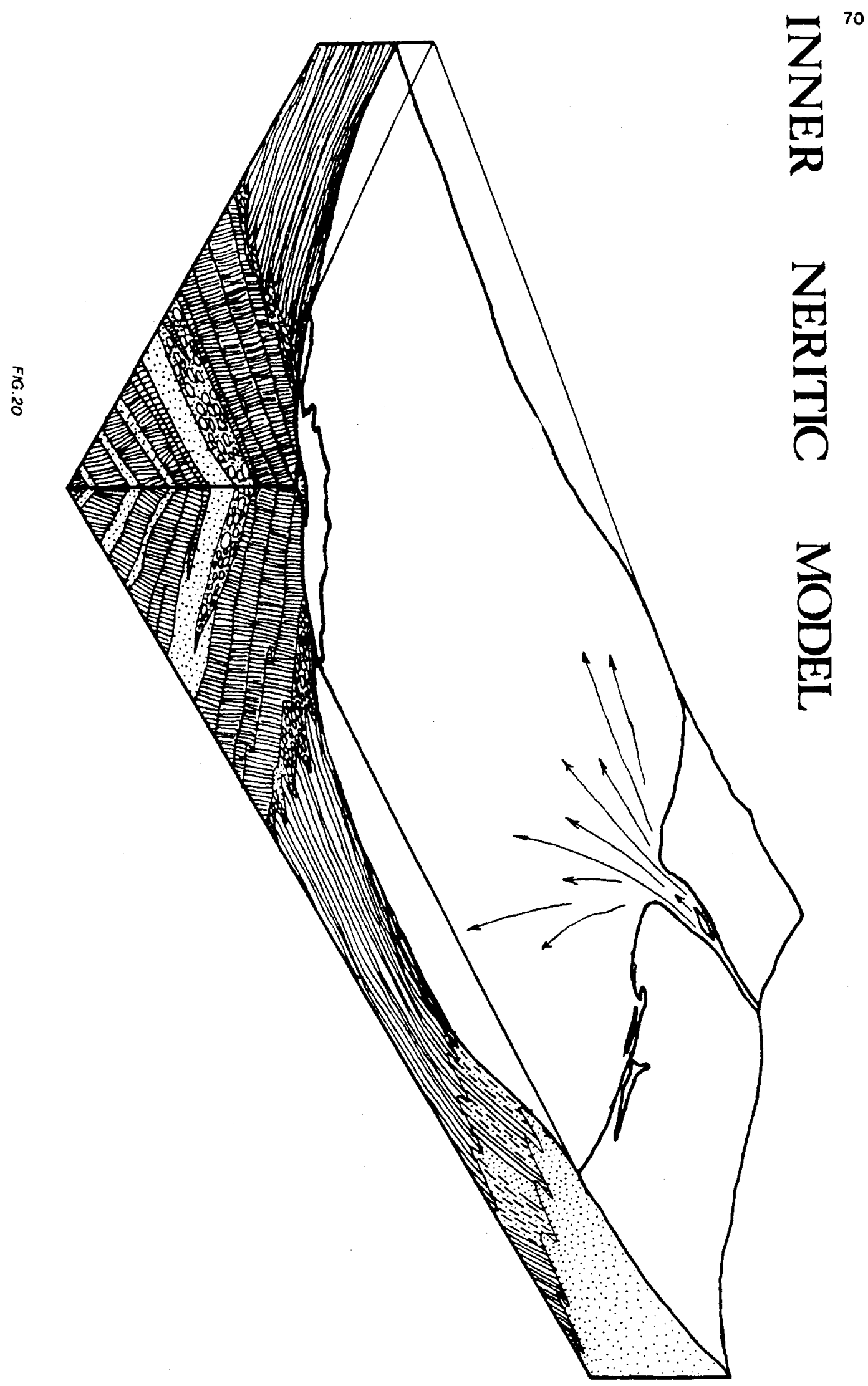


lacked the high velocities and consequently strong sorting ability of bottom currents in the narrower deeper channel at Mist.

Jackson (1983), Timmons (1981), Van Atta (1971) and many others have asserted that the clean upper sands of the Cowlitz Formation were deposited in a shallow, wave-dominated near-shore to beach environment, (fig. 19). This model is basically that of a ramp; deep-water mudstones give way to a heterolithic zone at intermediate depths, and sandstones replace these at shallower depths approaching a beach.

Jackson (1983, p. 87) noted the presence of hummocky cross stratification in the upper Cowlitz sand deposits. He interpreted this to indicate a storm-wave deposit. He cited sheet sand deposits on the modern northern California coast as an analogue. Jackson also indicated that he found shell layers, wood fragments, and mudclasts at the bases of Cowlitz sand layers, as well as ripples and other features as in the Northern California deposits of shallow depth.

In addition, both Jackson and Timmons found certain megafossils and trace fossils to reinforce their shallow water interpretations. These include the trace fossils Rosselia - Cylindrichus and? Thalassinoides in Cowlitz mudstones as well as the megafossil Brisaster. 


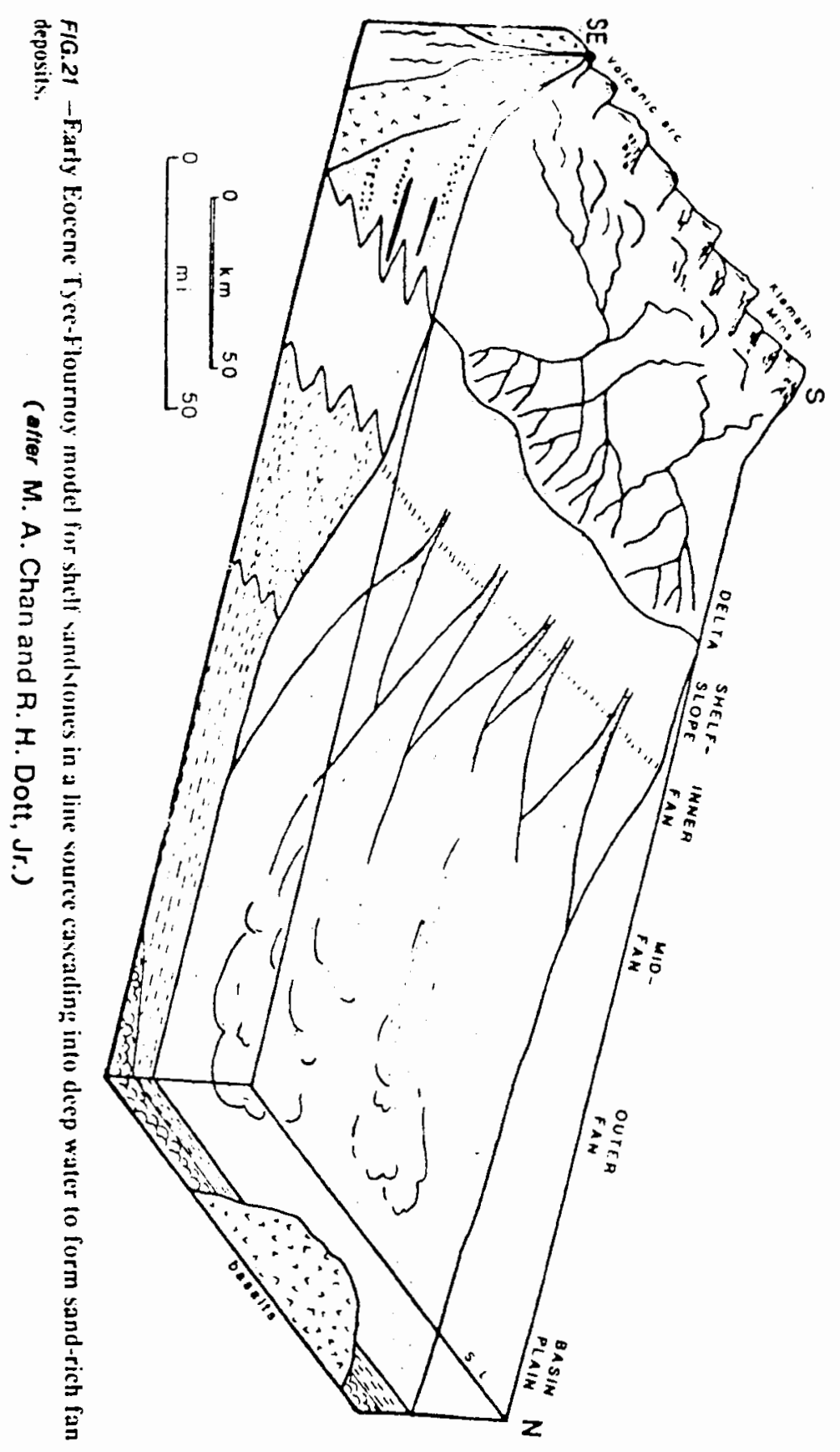


Jack Myers, geologist for Oregon Natural Gas Development Corp. (personal communication, 1984) advocated a "deep sea fan model" for the upper Cowlitz sands. He suggested that river-sorted sand was fed from a short shallow shelf and delta system down into deeper water. Myers noted similarities between electric log configurations from wells in the Mist Field sands with known subsea fans. He also pointed to the fact that arkosic sands of the Cowlitz are locally juxtaposed against Tillamook Volcanics rocks.

Myers adopted the model proposed by Chan and Dott (1983) and shown below in fig. 21. Although the Chan and Dott model referred to the early Eocene Tyee \& Flournoy Formations, Myers feels that the mechanisms were probably similar. He also notes that a deeper water interpretation is in conformity with the deep water interpretation (based on paleontological evidence) for much of the Cowlitz Formation siltstones both above and below the upper Cowlitz sands.

Armentrout (personal communication Jan., 1984) and others have advocated a "delta face model" for the upper Cowlitz sands (fig. 20). This interpretation rests on several facts: abundant plant material is found in the Cowlitz, its proximity to coal fields near Chehalis Washington, and a very thick (to $20,000 \mathrm{ft}$ )' accumulation within a depocenter immediately to the east, in the 
Willamette Valley. These lines of evidence suggest a nearby delta prograding westward during upper Eocene time.

Discussion - The inner neritic model ignores the fact that the microfossil assemblages found in the sediments of the Cowlitz Formation in Oregon are clearly outer neritic or more probably bathyal. Also, if the sands of the Cowlitz Formation were deposited very near shore, then why has no beach deposit ever been discovered nearby? Also the presence of abundant mica tends to refute the near-shore, wave-dominated, oscillatory motion included in the inner neritic model.

The "Deep Channel" model uses the Straits of Juan de Fuca as its modern analogue. Bruer cites the coarse sand and gravel on the bottom of the straights as evidence of traction load movement of sediments a fair distance from its source. The problem here lies in the fact that Pleistocene glaciers lay in an area which is now occupied by the Straits, leaving coarse morainal material upon the glaciers retreat.

The submarine Ean model calls for grainflow as a mechanism for the deposition of sand, yet does not adequately explain the presence of abundant crossbedding, alternating paleocurrent direction, and hummocky cross bedding of the upper Cowlitz sands. These sedimen- 
tary structures indicate a high energy environment with relatively strong currents.

This author suggests an "upper bathyal model" for the upper Cowlitz sand which is in conformity with the water depth determination of outer neritic depths, or bathal depths, (fig. 22, 23). This model utilizes the grainflow delivery mechanisms of the submarine fan model of Chan and Dott (1983) and Myers (1984) but also calls for the strong traction currents of Bruer's model to account for the alternating direction of cross bedding and sheet sand nature of the formation. In this model these energetic bottom currents distribute sand north and south of a fan center near Mist. This center is found seaward of a delta perched on a short shelf immediately to the east of the Mist area. River-winnowed sand cascades down the face of this delta and is distributed there in a fan.

This model accounts for the abundance of vitrinite in the upper Cowlitz sands by allowing for close proximity to the Cowlitz Delta. It does not demand sudden eustatic changes in sealevel; all deposition takes place in outer neritic to upper bathyal depths as indicated by foraminiferal assemblages. The deposition of finer-grained material prior to the deposition of sand is explained by the growth of the Cowlitz Delta on the shallow shelf. Sand accumulates on the delta until it reaches the shelf margin. 


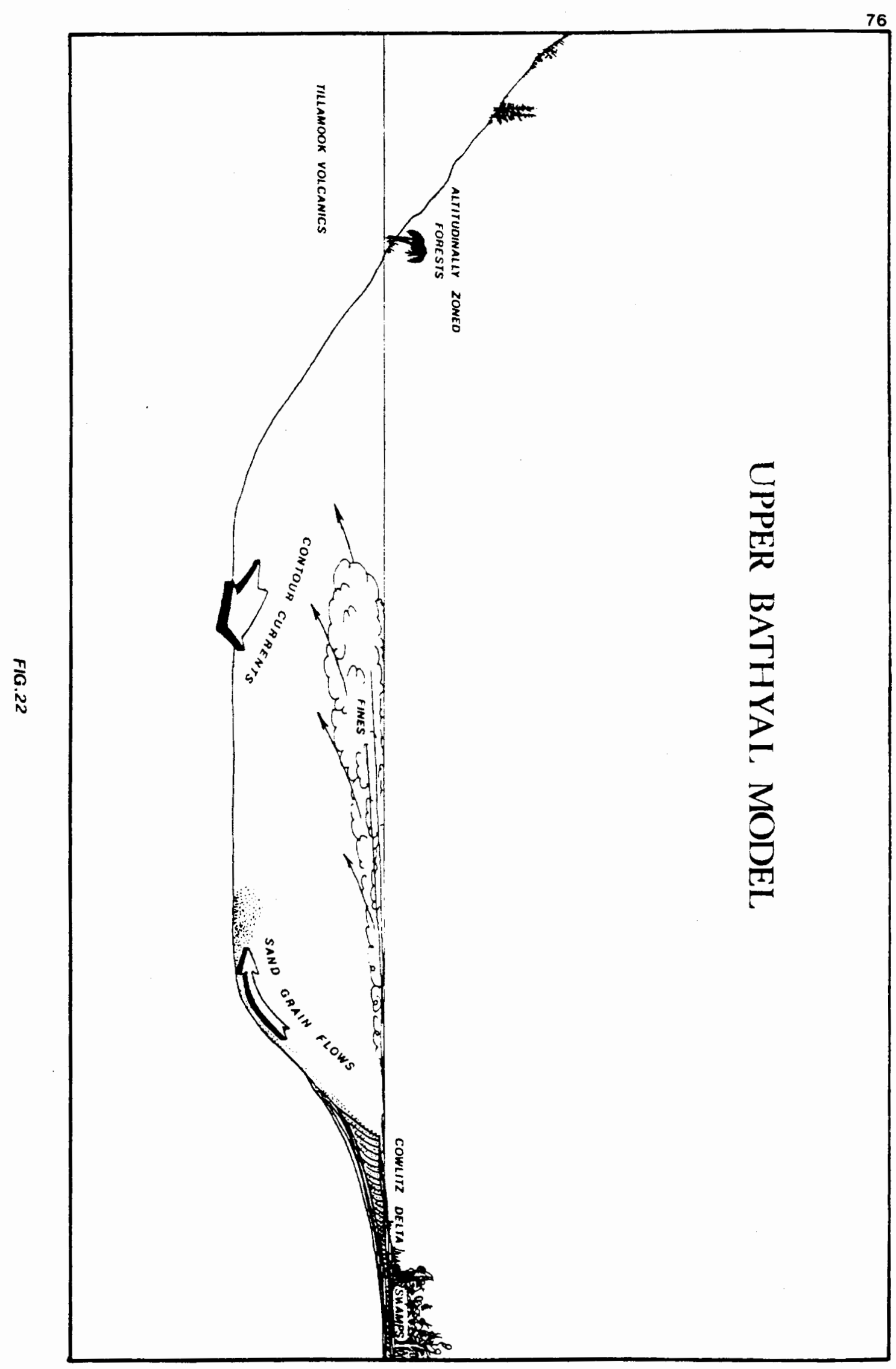


At that time large amounts of clean sands would begin to cascade over the margin into deeper water.

This author proposes that the environment of deposition of the Cowlitz Formation in Oregon was somewhat deeper than the inner neritic to middle neritic interpretation of Jackson, Van Atta, and Timmons and others who have also discussed the environment of deposition of the Cowlitz Formation in the Upper Nehalem River Basin. This author basically subscribes to the transgressive - regressive history of the formation as described by McKeel (1983, p. 3) and largely agrees with McKeels water depth determinations.

The wide variety of opinion concerning the environment of deposition of the Cowlitz Formation as well as inferred mechanisms of sediment transport appear to leave the door open to speculation. The model which is presented here is an attempt to bring together various lines of evidence. In doing so, the information generated by foraminiferal indicators of water depth, temperature and circulation were given greater weight than that generated from the interpretation of sedimentary structures or trace fossils. 
BATHYMETRIC CURVE

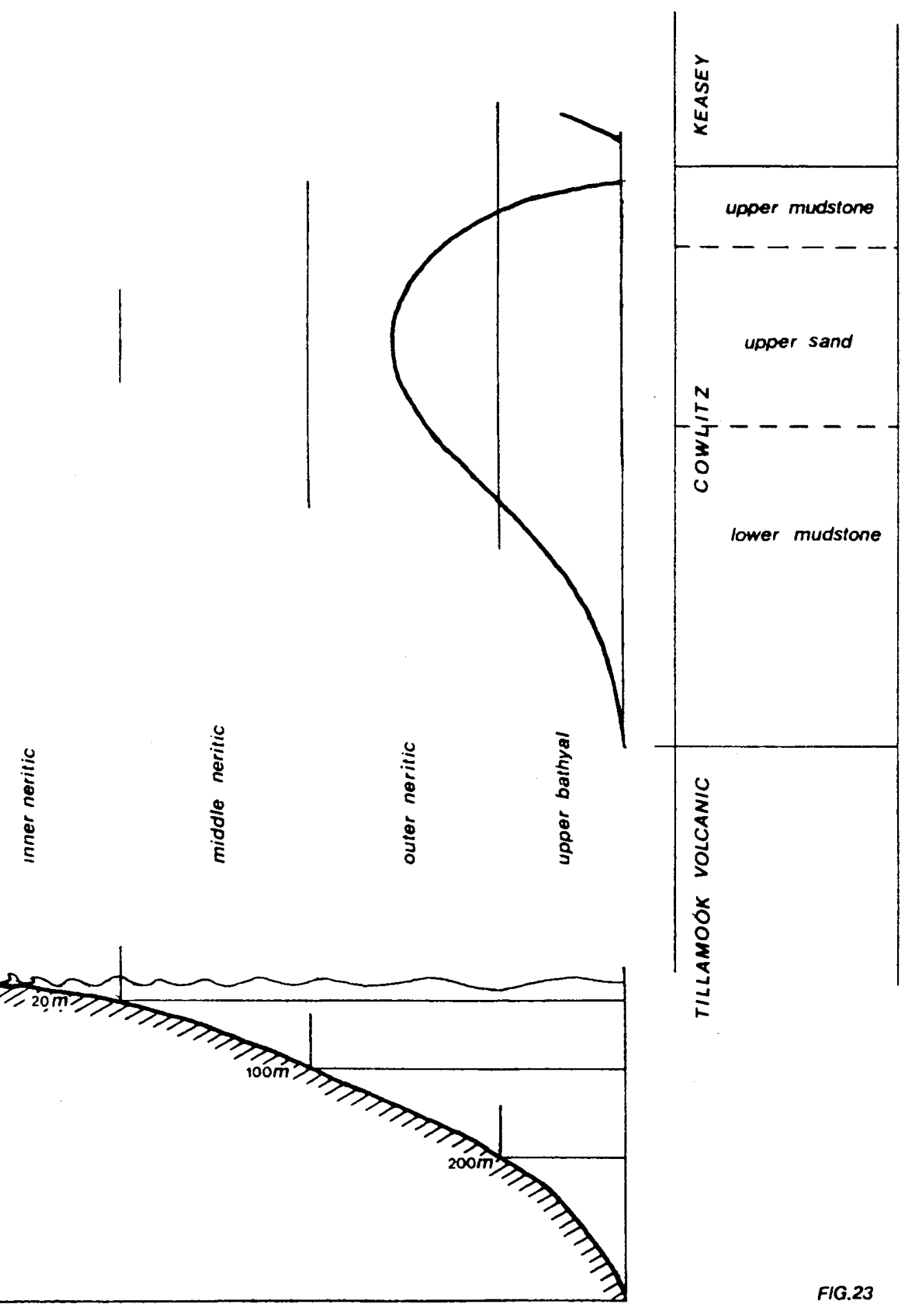


CHAPTER $V$

AGE AND CORRELATION

Local Biostratigraphy

The Cow1itz Formation was deposited during the Narizian Foraminiferal Stage of Mallory and the Bulimina schencki - Plectofrondicularia Cf P. jenkinsi zone of Rau is the only zone recognized. The lower portion of this zone is represented by the plectofrondicularia - Lenticulina faunule, comprising all of the Nehalem River Section, the lowermost portion of the Rock Creek Section, including sample sites PSUA250 - PSUA252, and the base of the Sunset Camp Section, including sample site PSUA259.

The intermediate portion of the composite section of this report is included in the Cibicides - Lenticulina faunule. This extends from sample site PSUA247 to PSUA 249 in the Rock Creek Section. In the sunset Camp Section this faunule is present in sample sites PSUA260 through PSUA266.

The uppermost faunule occurs in a single sampling site, PSUA267, assigned to the lowermost Keasey Formation, as well as the lower Refugian Stage of Rau. It is herein called the Ceratobulimina - Vaginulinopsis faunule. 
The stratigraphic occurrence of these faunules is shown in the correlation of sections, (fig. 16).

The Narizian-Refugian stage Boundary

The Cowlitz-Keasey contact is often gradational (Warren and Norbisrath, 1946), or at least difficult to pinpoint in the field. Likewise, the location of the Narizian - Refugian stage boundary with which it is sometimes coincident is often problematic, particularly in this section because the sediments which bracket the boundary and the contact are largely barren.

McKeel (1938) used the occurrence of Cibicides natlandi Beck to delimit the Narizian zone in the upper Nehalem River Basin in his micropaleontological analysis of drill cuttings from gas wells in the area. He also found that the rare occurrence of the planktonic form Pseudohastigerina micra (Cole) could be used to indicate a position just below the stage boundary. In the sunset Camp section $C$. natlandi occurs commonly up to and including the assemblage collected at locality PSUA266 but not above. P. micra makes its only appearance at this same locality. Therefore, the stage boundary probably occurs stratigraphically above this point.

The assemblage isolated from locality PSUA 267 contains many Refugian forms included in the Sigmorphina Schencki Zone species list of Rau (1981), 
including the first occurrences of the forms Vaginulinopsis Saundersi (Hanna and Hanna) and Marginulina alazanensis Nuttall. Samples taken approximately 25 meters stratigraphically above locality PSUA267 include such diagnostically lower Refugian forms as Melonis halkyardi (Cushman) and Pseudoglandulina inflata (Bornmann).

Forty meters stratigraphically below locality PSUA 267, nearly barren sediments display a sudden loss of mica, which was characteristically so abundant in all Cowlitz Formation sediments. This lithological contrast marks the Cowlitz-Keasey contact as defined by Van Atta (oral comm. 1985). For convenience, the stage boundary is herein assigned to this contact because it is bracketed by rocks containing assemblages which are representative of the Refugian Stage above and the Narizian stage below.

\section{Correlation}

Based on the assemblages found in samples taken from the measured sections of this study, the Cowlitz Formation can be correlated with the Type Cowlitz Formation in Washington, the Spencer, Yamhill, Nestucca, and Coaledo Formations of Oregon, the McIntosh Formation of Washington and the Tejon Formation of California. 
In the following synonomies, identifications are based primarily on published figures and descriptions. Special note has been made of species which have been compared with type material on deposit in the Earth Sciences Museum at Portland State University. The systematic arrangement of the foraminifera follows that of Cushman (1950).

\author{
Phylum PROTOZOA \\ Class SARCODINA Butschli, 1881 \\ Order FORAMINIFERA d'Orbigny, 1826
}

Family RHIZAMMINIDAE

Genus Bathysiphon M. Sars 1872

Bathysiphon eocenicus Cushman and G.D. Hanna

Bathysiphon eocenica Cushman and G.D. Hanna, Cushman and McMasters 1936, p. 508, pl. $74 \mathrm{fig} .1$ Weaver and Molander, 1964, p. 176, pl. l fig. 2; Gaston 1972 p. 46, [hypotype examined].

Bathysiphon eocenicus Cushman and G. P. Hanna, Mallory, 1959 p. 105, pl. 1 fig. 4; Callendar, 1977 p. 88 [hypotype examined], McDougall, 1980, p. $23 \mathrm{fig} \cdot 1$

Hypotype no. 00517 loc. PSUA 251

Family MILIOLIDAE

Genus Quinqueloculina 
Quinqueloculina imperialis Hanna and Hanna

Quinqueloculina imperialis Hanna and Hanna, Beck 1943, p. 592, pl. 98 figs. 9, 10; Rau, 1948, p. 159, pl. 27, figs. 12-14, Gaston, 1984 p. 51 [hypotype examined] Callendar, 1977, p. 90 [hypotype examined]

Hypotype no. 00518 loc. PSUA 251

\section{Family AMMODISCIDAE}

Genus Ammodiscus Reuss 1861

Ammodiscus coombsi Beck

Ammodiscus coombsi Beck plate 98, fig. 1

Hypotype no. 00519 loc. PSUA 251

\section{Family LITUOLIDAE}

Genus Cyclammina H.B. Brady 1876

\section{Cyyclammina pacifica Beck}

Cyclammina pacifica Beck, 1943, pl. 98 figs. 2, 3; Detling, 1946, p. 352, pl. 46, fig. 1; Cushman and Stewart, 1947, p. 74 pl. 9, figs. 1, 2; Rau, 1948 p. 157, pl. 27, figs. 7, 8; Rau 1951, p. 429, pl. 63, fig. 18 .

Hypotype no. 00520 loc. PSUA 249

\section{Family LAGENIDAE \\ Genus Dentalina}

Dentalina communis ( $d^{\prime}$ orbigny) 
Dentalina communis (d'orbigny) Beck, 1943, p. 598, pl.105, fig. 22; Smith, 1957, p. 165, pl. 22, fig. 9; Mallory, 1959, p. 162, pl. 12, fig. 11; pl. 4l, fig. 6; Gaston, 1974, p. 64 [hypotype examined]; Callendar 1977, p. 110 [hypotype examined]

Hypotype no. 00521 loc. PSUA 258

\section{Dentalina dusenburyi}

Hypotype no. 00522 loc. PSUA 262

$$
\text { Dentalina sp }
$$

Hypotype no. 00523 loc. PSUA 258

$$
\text { Genus Lagena }
$$

\section{Lagena sp.}

Hypotype no. 00524 loc. PSUA 267

Genus Lenticulina

\section{Lenticulina inornata (d'Orbigny)}

Lenticulina inornata (d'Orbigny) Tipton, Kleinpell, and Weaver, 1973 p. 45, pl. 2, fig. 9a, b; McDougall 1980, p. $41, \mathrm{pl} .7 \mathrm{figs} .11,12$.

Robulus inornatus (d'orbigny) Beck, 1943, p. 595 pl. 104, figs. 1 - 4; Mallory, 1959, p. 137, pl. 7, fig. 15a, b; pl. 40, fig. 5a, b; Callendar, 1977, p. 97 [hypotype examined]

[?] Robulus inornatus (d'orbigny) Gaston, 1974, p. 55 [hypotype examined].

Hypotype no. 00525 loc. PSUA 249 
Lenticulina texanus (Cushman and Applin) McDougall, 1980 , p. 41, pl. 7, figs. 14,15 .

Robulus texanus (Cushman and Applin) Beck 1943, p. 603, pl. 103, fig. l - 5; Rau, 1948, p. 164, pl. 29, fig. 16, 17.

Hypotype no. 00526 loc. PSUA 248

\section{Lenticulina welchi (Church)}

Lenticulina welchi (Church) McDougall, 1980, pl. 8, fig. 1 -4 .

Robulus welchi (Church) Beck, 1943, p. 596, pl. 102, fig. 4, 8; Detling, 1946, p. 353, pl. 48, fig. 2a, b; Rau, 1948, p. 161, pl. 28, fig. 16, 17; Mallory, 1959, p. 143, pl. 7, fig. 8a, b; Gaston, 1974, p. 58, (hypotype examined) Thoms, 1975, pl. 2, fig. la, b; Callendar, 1977, p. 102 (hypotype examined)

Hypotype no. 00527 loc. PSUA 255

$$
\text { Lenticulina sp. }
$$

Hypotype no. 00528 loc. PSUA 255

Genus Marginulina d'Orbigny, 1826 Marginulina sp.

Hypotype no. 00529 loc. PSUA 267

One incomplete specimen collected from the upper Sunset Camp Section exhibits the tight coiling of early chambers and uniserial arrangement of final chambers characteristic of this genus. The specimen resembles $M$. alazanensis. 


\section{Genus Nodosaria Lamarck 1812 \\ Nodosaria sp. a}

Hypotype no. 00530 loc. PSUA 255

Single fragment in the Rock Creek section was insufficient to further identify this specimen.

\section{Genus Pseudoglandulina Cushman 1929}

Pseudoglandulina ovata Cushman and Applin

Pseudoglandulina ovata Cushman and Applin, Mallory 1959, p. 174, pl. 28, fig. 9a, b; Gaston 1974, p. 70 [hypotype examined] Callendar 1977, p. 123 [hypotype examined].

Hypotype no. 00531 loc. PSUA 251

Genus Saracenaria De France

Saracenaria hantkeni Cushman

Saracenaria hantkeni Cushman, Beck, 1943, p. 606, pl. 106, fig. 9, 12; Mallory p. 153, pl. 27, fig. 19, a, b; McDougall, 1980, p. 42, pl. $9 \mathrm{fig} \cdot 12-17$.

Hypotype no. 00532 loc. PSUA 261

\section{Genus Vaginulinopsis \\ Vaginulinopsis saundersi (Hanna and Hanna)}

Vaginulinopsis saundersi (Hanna and Hanna) Beck, 1943, p. 598, pl. 105, figs. 1, 2, 4, 5, 10; Rau, 1948, p. 165, pl. 30, fig. 20-23; Mallory, 1959, p. 157, pl. 1l, fig. 10a, b; Gaston, 1974, p. 63, (hypotype examined); Callendar, 1977 p. 108, (hypotype examined); McDougall, 1980, p. 42, pl. 10, figs. 8, 9 . 
Hypotype no. 00533 loc. PSUA 267

$$
\text { Genus Vaginulina }
$$

Vaginulina sp.

Hypotype no. 00534 loc. PSUA 258

\author{
Family POLYMORPHINIDAE
}

Genus Globulina d'Orbigny 1839

$$
\text { Globulina landesi (Hanna and Hanna) }
$$

Globulina landesi (Hanna and Hanna), Beck 1943, p. 603, plate 106, figs. 14, 16, Mallory 1959, p. 178, pl. 36, figs. $13 a, b$.

Polymorphina landesi Hanna and Hanna, 1924, p. 60, pl. 13, figs. 16,17 .

Hypotype no. 00535 loc. PSUA 261

\title{
Genus Guttulina d'Orbigny 1839 \\ Guttulina irregularis (d'Orbigny)
}

Guttulina irregularia (d'Orbigny) Cushman 1935, p. 24, pl. 9, figs. 13 - 16; Beck 1943, p. 602, pl. 106, figs. 3 5; Mallory 1959, p. 177, pl. 14, fig. 13a, b; Gaston 1974, p. 72 (hypotype examined); Callendar, 1977, p. 127 (hypotype examined).

Hypotype no. 00536 loc. PSUA 262

Genus Pseudoglandulina

Pseudoglandulina conica (Neugeboren) 
Pseudoglandulina conica (Neugeboren) Beck 1943, p. 605, pl. 105, fig. 12; Mallory 1959, p. 173, pl. 33, fig. 4, pl. 36, fig. lla b.

Pseudonodosaria conica (Neugeboren) McDougall 1980, p. 43, pl. 9, fig. 7, 8 .

Hypotype no. 00537 loc. PSUA 259

Eamily HETEROHELICIDAE

Genus Plectofrondicularia Liebus, 1903

Plectofrondicularia packardi Cushman and Schenck

Plectofrondicularia packardi Cushman and Schenck,

Detling 1946, p. 355, pl. 49, fig. 1; Mallory, 1959, p. , pl. fig. , Callendar 1977, p. 134 [hypotype examined]; McDougall, 1980, p. 42, pl. 11, figs. 1, 2 .

Plectofrondicularia packardi multilineata Cushman and Simonson, Rau, 1948, p. 165, pl. 30, fig. 19.

Hypotype no. 00538 lOc. PSUA 249

\section{Family BULIMINIDAE}

Genus Bolivina d'Orbigny, 1839

Bolivina basisenta Cushman and stone

Bolivina basisenta Cushman and Stone, Gaston 1974, p. 80 [hypotype examined] Callendar 1977, p. 151 [hypotype examined]

Hypotype no. 00539 loc. PSUA 258

Bolivina Klienpelli Beck

Bolivina kleinpelli Beck, 1943, p. 606, pl. 107, fig. 39; Mallory, 1959, p. 201, pl. 16, fig. 20; Gaston, 1974, p. 81 
[hypotype examined]; Callendar, 1977, p. 152 [hypotype examined]; McDougall, 1980, pl. 14, figs. 5, 6.

Hypotype no. 00540 loc. PSUA 2

\section{Genus Bulimina}

\section{Bulimina schencki Beck}

Bulimina schencki Beck

Hypotype no. 00541 loc. PSUA 255

$$
\text { Bulimina sp. }
$$

Hypotype no. 00542 loc. PSUA 250

One poorly preserved specimen from the Rock Creek

Section seems best referred to this genus.

Genus Globobulimina Cushman 1927

\section{Globobulimina pacifica Cushman}

Globobulimina pacifica Cushman, Mallory, 1959, pl. 16, fig. 17; Gaston, 1974, p. 79 (hypotype examined); Callendar, 1977, p. 148 (hypotype examined).

Globobulimina cf. G. pacifica Cushman, Rau, 1948, p. 171, pl. 30, fig. 5; Weaver and Weaver, 1962, p. 32, pl.9, fig. 16 .

Hypotype no. 00543 loc. PSUA 252

$$
\text { Globobulimina sp. }
$$

Hypotype no. 00544 loc. PSUA 252 
One poorly preserved specimen from the Rock Creek

Section seems best referred to this genus.

\section{Genus Trifarina Cushman 1923 \\ Trifarina hanni Beck}

Trifarina hanni Beck, McDougall, 1980, p. 37, pl. , fig. Angulogerina hanni Beck, 1943, p. $607-608$, pl. 108, figs. 26,28 .

Hypotype no. 00545 loc. PSUA 261

Family ROTALIIDAE

Genus Gyroidina D'Orbigny, 1826

Gyroidina condoni (Cushman and Schenck)

Gyroidina condoni (Cushman and Schenck), Tipton, Klienpell, and Weaver, 1973, p. 60, pl. 9, fig. la - c; Gaston, 1974, p. 85 (hypotype examined); Thoms, 1975, pl. 3, fig. 6 a - c; Callendar, 1977, p. 161 (hypotype examined); McDougall, 1980, p. 46, pl. 27, fig. 5 .

Hypotype no. 00546 loc. PSUA 249

Gyroidina orbicularis d'orbigny var. planata Cushman

Gyroidina orbicularis d'orbigny var. planata, Cushman, Weaver and Weaver, 1962, p. 36, pl. 13, fig. la - c.

Gyroidina orbicularis planata Cushman, Rau, 1948, p. 171, pl. 31, fig. 12 - 14; Gaston, 1974, p. 86, (hypotype examined); Thoms, 1975, pl. 2, fig. 18 a - c; Callendar, 1977, p. 162 (hypotype examined); McDougall, 1980, p. 46 , pl. 27 , figs. $7-9$.

Hypotype no. 00547 10c. PSUA 267 
Family CASSIDULINIDAE

Genus Ceratobulimina Toula 1915

Ceratobulimina washburnei Cushman and Schenck

Ceratobulimina washburnei Cushman and Schenck, Beck, 1943, pl. 108, figs. 20, 24; Rau, 1948, pl. 31, figs. 15 17; McDougall, 1980, pl. 29, figs. 10, 11 .

Hypotype no. 00548 loc. PSUA 267

\section{Genus Eponides Montfort, 1808}

\section{Eponides mexicana (Cushman)}

Eponides mexicana (Cushman), Mallory, 1959, p. 237, pl. 37, fig. 11; Weaver and Weaver, 1962, p. 37, pl. 13, fig. $4 a$ - c; Gaston, 1974, p. 86, (hypotype examined); Thoms, 1975, pl. 3, fig. 3a - c; Callendar, 1977. p. 165 (hypotype examined); McDougall, 1980, p. 45, pl. 23, figs. 7 - 9 .

Eponides yeguaensis Weinzierl and Applin, Beck, 1943, p. 608, pl. 108, figs. 1, 4.

Hypotype no. 00549 loc. PSUA 251

Genus Globocassidulina d'orbigny, 1826

\section{Globocassidulina globosa (Hantken)}

Cassidulina globosa Hantken, Beck, 1943, p. 611, pl. 108, figs. 7, 13, 14; Detling, 1946, p. 358, pl. 51, fig. 3a, b; Mallory, 1959, p. 226, pl. 33, fig. 1la, b; Weaver and Weaver, 1962, p. 38, pl. 16, fig. 3a - c; Gaston, 1974, p. 89 (hypotype examined); Callendar, 1977, p. 171 (hypotype examined).

Globocassidulina globosa (Hantken), Smith, 1971, p. 63, pl. 9, fig. 6a, b. 
Hypotype no. 00550 loc. PSUA 251

Family CHILOSTOMELLIDAE

Genus Allomorphina Reuss 1850

Allomorphina macrostoma Karrer

Allomorphina macrostoma Karrer, Beck, 1943, pl. 108, figs. 7, 13, 14; Rau, 1948, pl. 31, figs. 4, 5; Gaston, 1974, p. 90 (hypotype examined); Callendar, 1977, p. 172 (hypotype examined).

Hypotype no. 00551 loc. PSUA 250

\title{
Family HANTKENINIDAE
}

Genus Pseudohastigerina Banner and Blow, 1959 Pseudohastigerina micra (Cole)

Nonion micrum Cole, Mallory, 1959, p. 181, pl. 15, figs. 3a - c; Thoms, 1975, pl. 4, fig. 3a, b.

Pseudohastigerina micra (Cole) Gaston, 1974, p. 91, (hypotype examined); Callendar, 1977, p. 174 (hypotype examined).

Hypotype no. 0052 loc. PSUA 267

\author{
Family ANOMALINIDAE \\ Genus Cibicides Montford, 1808 \\ Cibicides baileyi Beck
}

Cibicides baileyi Beck, 1943, pl. 109, figs. 7 - 9 . Hypotype no. 00553 loc. PSUA 250 
Cibicides hodgei Cushman and Schenk

Boldia hodgei (Cushman and Schenck), McDougall, 1980, pl. 29, figs. $4-6$.

Cibides hodgei Cushman and Schenck, Beck 1943, pl. 109, fig. 24 - 28; Mallory, 1959, p. 265, pl. 24, figs.6a - c; Hornaday, 1961, pl. 13, fig. la - c; Callendar, 1977, p. 181 (hypotype examined).

Hypotype no. loc. PSUA 255

\section{Cibides natlandi Beck}

Cibicides natlandi Beck, 1943, pl. 109, figs. 1, 5, 13; McDougall, 1980, pl. 24, figs. 7 - 9 .

Hypotype no. 00555 loc. PSUA 260

$$
\text { Cibicides p. }
$$

Hypotype no. 00556 loc. PSUA 261

One poorly preserved specimen from the sunset Camp Section was referred to this genus. 
All of the following localities are found in the eastern Nehalem River valley in an area approximately described by a triangle with points at Keasey, Cochran and Timber, oregon. This includes western parts of Columbia and Washington Counties and to a very limited extent the easternmost portion of Tillamook County. The United States Geological Survey Map of the Timber Quadrangle (15 minute series, scale $1: 62500,1955)$ and the United States Geological Survey Map of the Clear Creek Quadrangle (15 minute series, scale 1:62500, 1955) were used here. Locality numbers refer to the collections of the Earth Sciences Museum of Portland State University, Portland, Oreqon. Localities are listed below as they appear in their respective measured sections.

Nehalem River Section

Representing the lowermost portion of the Cowlitz Formation and including its contact with the Tillamook Volcanics Series, this section was measured along the upper Nehalem River west of Timber, Oregon. The Nehalem River flows southeast here (fig. 5) along a fairly straight line which may be fault controlled.

The beginning and lowermost point stratigraphically, of the traverse occurs in the $\mathrm{NW} 1 / 4, \mathrm{NW} 1 / 4, \mathrm{SW} 1 / 4$ of section $30, T 3 N, R 5 W$. This point is marked by a smooth, 
black, massive basalt outcropping in the riverbank which is the last basalt flow recognizable in moving downstream (upsection) and is recognized in this report as the lower contact of the Cowlitz Formation. The final point on the traverse, also in the Nehalem River, is at locality PSUA 258 (fig. 5). At this point the course of the river swings to the northeast where it approximates strike. This point is located in the $\mathrm{SE} 1 / 4, \mathrm{NE} 1 / 4, \mathrm{NE} 1 / 4, \operatorname{section} 31, \mathrm{~T} 3 \mathrm{~N}$, R5W. The section as a whole begins in basaltic conglomerate, and ends in mudstone. All foraminiferal samples were taken from the bottom and banks of the Nehalem River.

Locality PSUA 253

Located on the north bank of the Nehalem River, 22.3 meters stratigraphically above the base of the Nehalem River section as described above. The rock here is a fine grained, greenish-gray tuffaceous siltstone.

\section{Locality PSUA 254}

Located on the south bank of the Nehalem River, 103.2 meters stratigraphically above the base of the section in well-bedded, medium-gray, soft mudstone. 
Located on the bottom of the Nehalem River 117.1 meters stratigraphically above the base of the section in medium-gray, "greasy" claystone.

\section{Locality PSUA 256}

Located on the bottom of the Nehalem River 161.7 meters stratigraphically above the base of the section in light-gray, well-bedded mudstone.

\section{Locality PSUA 257}

Located on the bottom of the Nehalem River 206.4 meters stratigraphically above the base of the section in medium-gray, poorly bedded to massive, bioturbated, micaceous siltstone.

\section{Locality PSUA 258}

Located on the bottom of the Nehalem River 253.5 meters stratigraphically above the base of the section in medium-gray massive, micaceous siltstone.

\section{Rock Creek Section}

This section was measured along the bed of Rock Creek (fig. 8) from a ruined railroad trestle upstream of the former townsite of Keasey to a point immediately west of the town. Cowlitz Formation rocks are faulted against Tillamook Volcanics rocks at a point several hundred 
yards below the ruined railroad trestle, therefore all

collections were made downstream of this contact to the termination of the traverse imme-diately west of Keasey. The quarter section descriptions of these three points are: trestle; SE 1/4, NW 1/4, SW 1/4, Sec. 5, T4N, R5W, contact; $\mathrm{NE} 1 / 4, \mathrm{NW} 1 / 4, \mathrm{SW} 1 / 4$, Sec. 5, T4N, R5W, Keasey; NW 1/4, SE 1/4, NW 1/4, Sec. 5, T4N, R5W. Locality PSUA 252

Located in the east bank of Rock Creek 6.3 meters stratigraphically above the base of the section west of Keasey in calcareous light gray mudstone.

\section{Locality PSUA 251}

Located in the bottom of Rock Creek 18.4 meters stratigraphically above the section base in laminar, bedded, lignite-rich dark-gray, siltstone.

\section{Locality PSUA 250}

Located in the bottom of Rock Creek 30.7 meters stratigraphically above the base in medium gray, well bedded mudstone.

Locality PSUA 249

Located in the bottom of Rock Creek 42.3 meters stratigraphically above the base in light-gray, thinbedded, coarse siltstone. 
Locality PSUA 248

Located in the north bank of Rock Creek 79.1 meters stratigraphically above the base in light-gray, finegrained, sandy, planar, bedded siltstone.

\section{Locality PSUA 247}

Located in the bottom of Rock Creek 121.7 meters stratigraphically above the base in medium-gray, massive siltstone.

\section{Sunset Camp Section}

This long section follows the Nehalem River from the Sunset Highway bridge at Timber Junction to a logging company bridge approximately two kilometers upstream. The base of the section occurs at the bridge at Timber Junction. The uppermost portion of the section includes the Cowlitz-Keasey contact as well as a few tens of meters of the basal keasey Formation. The quarter section coordinate for the lower and upper bridges are respectively: $\mathrm{SW} 1 / 4$, $\mathrm{SW}$ 1/4, NW 1/4, Sec. 10, T3N, R5W, and SW 1/4, SW 1/4, NE 1/4, Sec. 15, T3N, R5W.

\section{Locality PSUA 259}

Located on the bottom of the Nehalem River 15.6 meters stratigraphically above the base in medium-gray, well-bedded siltstone. 
Located on the bottom of the Nehalem River 43.7 meters stratigraphically above the base in medium-gray, soft, bioturbated mudstone.

\section{Locality PSUA 261}

Located on the bottom of the Nehalem River 68.7 meters stratigraphically above the base in medium-gray, micaceous, bioturbated mudstone.

\section{Locality PSUA 262}

Located on the bottom of the Nehalem River 109.4 meters stratigraphically above the base in medium-gray, micaceous, well-bedded siltstone.

\section{Locality PSUA 263}

Located on the eastern bank of the Nehalem river 168.7 meters stratigraphically above the base in dark gray, micaceous, calcareous mudstone.

\section{Locality PSUA 264}

Located on the bottom of the Nehalem River 225.3 meters stratigraphically above the base in light gray, micaceous siltstone. 


\section{Locality PSUA 265}

Located on the western bank of the Nehalem River 262.5 meters stratigraphically above the base in dark, gray-green, lignitic, micaceous siltstone.

\section{Locality PSUA 266}

Located on the bottom of the Nehalem River 300.1 meters stratigraphically above the base in light gray, calcareous, well indurated, sandy siltstone.

\section{Locality PSUA 267}

Located on the bottom of the Nehalem River 463.5 meters stratigraphically above the base in medium-gray, tuffaceous, fine grained, non-micaceous mudstone. 


\section{BIBLIOGRAPHY}

Al-Azzaby, F. A. Stratigraphy and sedimentation of the Spencer Formation in Yamhill and Washington Counties, Oregon: Portland State Univ., Portland, Oregon, unpub. M.S. thesis, 104 p.

Armentrout, J.M., 1981, Correlation and ages of Cenozoic chronostratigraphic units in oregon and Washington: GSA Special Paper 184, p. 137-148.

Armentrout, J. M., and Franz, U. A., 1983, Tectonic control of Eocene arkosic sediment deposition, Oregon and Washington: American Association of Petroleum Geologists, v. 67, no. 3, p. 413-414.

Armentrout, J. M. and Suek, D. H., 1984, Hydrocarbon Exploration in Western Oregon and Washington: Amer. Assoc. Petrolem Geol. Bulletin, 44 p.

Axelrod, D. I., 1968, Tertiary floras and topographic history of the snake River Basin, Idaho: Geol. Soc. Amer. Bull., v. 79, p. 713-734.

Baldwin, E. M., 1964a. Geology of Oregon: 2nd ed., Ann Arbor, Michigan, Edwards Brothers, Inc., $165 \mathrm{p}$.

Bandy, O. L., and Arnal, R. E., 1960, Concepts of foraminiferal paleoecology: Am. Assoc. Petroleum Geologists Bull., v. 44, n. 12, p. 1921-1932, 14 fig.

Beck, R. S., 1943, Eocene Foraminifera from the Cowlitz River, Lewis County, Washington: Jour. Paleon., v. 17, n. 6, p. 584-614, pl. 98-109, $4 \mathrm{fig}$.

Bruer, W. G., 1980, Mist Gas Field, Columbia County, Oregon: Amer. Assoc. Petroleum Geol. - Soc. Econ. Geol. Technical Program Reprints, Pacific Sections, Fifty-fifty annual meeting, $10 \mathrm{p}$. 
Callendar, A. D., 1977, Middle and Upper Eocene Biostratigraphy, (Foraminifera) of the Cascade Head Area, Lincoln and Tillamook Counties, Oregon: Portland State Univ., Portland, Oregon, M. S. Thesis, $210 \mathrm{p}$.

Cameron, K. A., 1980, Geology of the south central margin of the Tillamook Highlands; southwest quarter of the Enright quadrangle, Tillamook County, Oregon: Portland State Univ., Portland, Oregon, unpub. M. S. thesis, $87 \mathrm{p}$.

Chaney, R. W., and Sanborn, E. I., 1933, The Goshen flora of west central Oregon; Carnegie Inst. Wash. Pub. 439.

Chaney R. W. 1938, Ancient forests of Oregon: a study of earth history in western America. Cooperation in research. Carnegie Inst. Wash. Pub. 501: 631-648.

Cushman, J. A., and Barksdale, J. D., 1930, Eocene Foraminifera from Martinez, California: Stanford Univ., Dept. Geol., Contr., v. 1, n. 2, P. 55-73, pl. 1112 .

Cushman, J. A., and Schenck, H. G., 1928, Two foraminiferal faunules from the oregon Tertiary: Univ. Calif. Publ. Geol. Sci., v. 17, p. 305-325, pl. 4245 .

Cushman, J. A., Stewart, R. E. and Stewart, K. C., 1947a. Astoria Miocene Foraminifera from the northwest corner of Tenth Street and Harrison Avenue, Astoria, Clatsop County, Oregon: Ore. Dept. Geol. and Min. Ind. Bull., v. 36, pt. 1, p. 9-40, pl. 1-4.

Cushman, J. A., Stewart, R. E. and Stewart, K. C., $1947 \mathrm{~b}$. Astoria Miocene Foraminifera from Agate Beach, Lincoln County, Oregon: Ore. Dept. Geol. and Min. Ind. Bull., v. 36, pt. 2, p. 4l-56, pl. 5-6, l fig. 
Cushman, J. A., Stewart, R. E. and Stewart, K. C., 1947c. Upper Coaledo (upper Eocene) Foraminifera from Yokam Point, Coos County, Oregon: Ore. Dept. Geol. and Min. Ind. Bull., v. 36, pt. 3, p. 57-70, pl. 7-8, 1 fig.

Cushman, J. A., stewart, R. E. and Stewart, K. C., 1947d. Lower Coaledo (upper Eocene) Foraminifera from Sunset Bay, Coos County, Oregon: Ore. Dept. Geol. and Min. Ind. Bull., v. 36, pt. 4, p. 71-92, pl. 9-1l, 1 fig.

Cushman, J. A., Stewart, R. E. and Stewart, K. C., 1947e. Eocene Foraminifera from Helmick Hill, Polk County, Oregon: Ore. Dept. Geol. and Min. Ind. Bull., v. 36, pt. 5, p. 93-111, pl. 12-13, l fig.

Cushman, J. A., Stewart, R. E. and Stewart, K. C., 1949. Upper Eocene Foraminifera from the Toledo Formation, Toledo, Lincoln County, Oregon: Ore. Dept. Geol. and Min. Ind. Bull, v. 36, pt. 6, p. 126-146, pl. $14-16$, 1 fig.

Detling, L. E., 1968, Historical background of the flora of the Pacific Northwest: Eugene, Oregon, Museum of Natural History, University of Oregon Pub. no. 13, 59 p.

Deacon, R. J., 1953, A revision of upper Eocene and lower Oligocene stratigraphy in the upper Nehalem River basin, northwest Oregon: Oregon State Univ., Corvallis, unpub. M.S. thesis, $84 \mathrm{p}$.

Dickinson, W. R., and Suczek, C. A., 1979, Plate tectonics and sandstone compositions: Amer. Assoc. Petroleum Geol. Bull., v. 63, no. 12, p. 2164-2182.

Diller, J. C., 1896, A geological reconnaissance in northwestern Oregon: U.S. Geol. Survey, 17th Annual Report, p. 441-520. 
Dott, R. H., Jr., and Bird, K., 1979, Sand transport through channels across an Eocene shelf and slope in southwestern oregon, in Doyle, L. J., and Pilkey, O.H., eds., Geology of Continental slopes: Society of Economic Paleontologists and Mineralogists, Special Publication No. 27, p. 327-342.

Duncan, R. A., 1982, A captured island chain in the Coast Range of Oregon and Washington: Journal of Geophysical Research, v. 87, no. B13, p. 10,82710,837 .

Gaston, L. R., 1974, Biostratigraphy of the type Yamhill Formation, Polk County, Oregon: Dept. Earth Science, Portland State Univ., Portland, Oregon, Unpub. M. S. Thesis, $139 \mathrm{p} ., 4 \mathrm{fig}$.

Gray, J., 1964, Northwest American Tertiary palynology: the emerging picture. Ancient Pacific floras. Tenth Pacific Science Congress Series, Honolulu: 21-30.

Hanna, G. D., 1923, Some Eocene Foraminifera near Vacaville, California: Univ. Calif. Publ. Geol. Sci., v. 14, n. 9, p. 319-328, pl. 58-59.

Hanna, G. D., and Hanna, M. A., 1924, Foraminifera from the Eocene of Cowlitz River, Lewis County, Washington: Univ. Wash. Publ. Geol., v. 1, n. 4, p. $57-64$, pl. 13 .

Henricksen, D. A., 1956, Eocene stratigraphy of the lower Cowlitz River - Eastern Willapa Hills area, southwestern Washington: Washington Div. Mines and Geol. Bull. 43, $122 \mathrm{p}$.

Jackson, M. K., 1983, Geology of the Upper Nehalem River - Wolf Creek Area Northeastern oregon: Portland State Univ., Portland, Oregon, M. S. Thesis 
Jenkins, D. G., 1971, New Zealand Cenozoic planktonic Foraminifera: New zealand Geol. Survey Bull. 42, $278 \mathrm{p} ., 23 \mathrm{pl} ., 2 \mathrm{fig}$.

Kadri, M. M., Beeson, M. H., and Van Atta, R. O., 1983, Geochemical evidence for changing provenance of Tertiary formations in northwest oregon: Oregon Geology, v. 45, p. 20-22.

Kelty, K. B., 1981, Stratigraphy, lithofacies, and environment of deposition of the Scappoose Formation in central Columbia County, oregon: Portland State Univ., Portland, oregon, unpub. M.S. thesis, $81 \mathrm{p}$.

Kleinpell, R. M., and Weaver, D. W., 1963, Oligocene biostratigraphy of the Santa Barbara Embayment, California: Univ. Calif. Publ. Geol. Sci., v. 43, 250 p., $38 \mathrm{pl} ., 8 \mathrm{fig}$.

Kunnar and Slatt, Submarine - Fan and Slope Facies of Tonkawa (Missourian-Virgilian) Sandstone in deep Anadarko Basin, A.A.P.G., vol. 68, \#12.

Magill, J. R., Cox, A. V., and Duncan, R., 1981, Tillamook Volcanic Series: further evidence for tectonic rotation of the Oregon Coast Range: Jour. Geophysical Research, v. 86, p. 2953-2970.

Mallory, V. S., 1959, Lower Tertiary biostratigraphy of the California coast ranges: Amer. Assoc. Petroleum Geol., Tulsa, Oklahoma, 416 p.

McDougall, K., 1975, The microfauna of the type section of the Keasey Formation of northwestern Oregon, in Weaver, D. W., Hornaday, G. R., and Tipton, A., eds., Paleogene Symposium and Selected Technical Papers, Annual Meeting Pacific Sections, AAPG, SEPM, SEG, Long Beach, California. 
McDougall, K., 1983, Paleoecological Evaluation of Late Eocene Biostratigraphic Zonations of the Pacific Coast of North America: S.E.P.M. Paleontological Monograph 2 .

Magill, J. R., Wells, R. E., Simpson, R. W., and Cox, A. V., 1982 , Post $12 \mathrm{~m} \cdot \mathrm{y}$. rotation of southwest Washington: Journal of Geophysical Research, v. 87 , no. B5, p. 3761-3776.

Mckee, B., 1972, Cascadia, the Geologic Evolution of the Pacific Northwest: New York, McGraw-Hill Book Company, $394 \mathrm{p}$.

Mckeel, D. R., and Lipps, J. H., 1975, Eocene and Oligocene planktonic Foraminifera from the central and southern Oregon Coast Range: Jour. Foram. Research, v. 5, n. 4, p. 249-269, $5 \mathrm{pl}$., $3 \mathrm{fig}$.

Natland, M. L., 1933, The temperature and depthdistribution of some Recent and fossil Foraminifera in the southern California region: Bull. Scripps. Inst. Oceanog., Tech. Ser., v. 3, n. 10, p. 225-230, 1 chart.

Nelson, D. E., 1984, Geology of the Fishhawk Falls-Jewell Area, Southeastern Clatsop County, Northwest Oregon: Corvallis, Oregon, Oregon State University Masters Thesis (in preparation).

Niem, A. R., 1976, Tertiary volcaniclastic deltas in a forearc setting, western oregon: Geological society of America, Abstracts with Programs, v. 8, no. 3, p. 400 .

Niem, A. R., and Van Atta, R. O., 1973, Cenozoic stratigraphy of northwestern oregon and adjacent southwestern Washington, in Geologic field trips in northern Oregon and southern Washington: Oregon Dept. Geol. and Min. Industries Bull. 77, p. 75-132. 
Newton, V. C., 1969, Subsurface geology of the lower Columbia and Willamette Basins, Oregon: Oregon Department of Geology and Mineral Industries, oil and Gas Investigations No. 2, 121 p., 7 plates.

Newton, V. C., and Van Atta, R. O., 1976, Prospects for natural gas production and underground storage of pipeline gas in the upper nehalem River Basin, Columbia-Clatsop Counties, Oregon: Oregon

Department of Geology and Mineral Industries, Oil and Gas Investigations 5, 56 p., 1 map.

Olbinski, J. S., 1983, Geology of the Buster Creek Nehalem Valley Area, Clatsop County, Northwest Oregon: Corvallis, Oregon, Oregon State University Masters Thesis.

Rau, W. W., 1948, Foraminifera from the Porter Shale (Lincoln Formation), Grays Harbor County, Washington: Jour. Paleon., v. 22, n. 2, p. 152-174, pl. 27-31, $1 \mathrm{fig}$.

Rau, W. W., 1964, Foraminifera from the northern Olympic Peninsula, Washington: U. S. Geol. Survey Prof. Paper $374-\mathrm{G}, 33 \mathrm{p} ., 7 \mathrm{pl} ., 2 \mathrm{fig}$.

Rau. W. W., 1966, Stratigraphy and Foraminifera of the Satsop River area, southern olympic Peninsula, Washington: Washington Division of Mines and Geology Bulletin 53, 66 p.

Raup, D. M., and Stanley, S. M., 1971, Principles of paleontology: San Francisco, W. H. Freeman and Company, $388 \mathrm{p}$.

Schenck, H. G., and Kleinpell, R. M., 1936, Refugian Stage of Pacific Coast Tertiary: Am. Assoc. Petroleum Geologists Bull., v. 20, n. 2, p. 215-225. 
Snavely, P. D., Jr., and Baldwin, E. M., 1948, Siletz River Volcanic Series, northwestern oregon: Am. Assoc. Petroleum Geologists Bull., v. 32, n. 5, p. 805-812, $4 \mathrm{fig}$.

Snavely, P. D., Jr., Brown, R. D., Jr., Roberts, A. E., and Rau, W. W., 1958, Geology and coal resources of the Centralia-Chehalis district, Washington: U. S. Geological Survey Bulletin 1053, 195 p.

Snavely, P. D., Jr., MacLeod, N. S., and Rau, W. W., 1970, Summary of the Tillamook area, northern oregon Coast Range: U. S. Geol. Survey, Research 1969, Prof. Paper 650-A, p. A47.

Snavely, P. D., Jr., Pearl, J. E., and Lander, D. L., 1977, Interim report on petroleum resources potential and geologic hazards in the outer continental shelf Oregon and Washington Tertiary province: U. S. Geological Survey Open - file Report 77-282, 64 p.

Snavely, P. D., Jr., Rau, W. W. , Hoover, Linn, Jr., and Roberts, A. E., 1951, McIntosh Eormation, CentraliaChehalis coal district, Washington: Am. Assoc. Petroleum Geologists Bull., v. 35, n. 5, p. 1052$1061,6 \mathrm{fig}$.

Snavely, P. D., Jr., and Wagner, H. C., 1963, Tertiary geologic history of western Oregon and Washington: Washington Div. Mines and Geol., Reports of Investigations, No. $22,25 \mathrm{p}$.

Snavely, P. D., and Wagner, H. C., 1964, Geologic sketch of Northwestern Oregon: U. S. Geological Survey Bulletin 1181-M, $17 \mathrm{p}$.

Snavely, P. D., Wagner, H. C., and Lander, D. L., 1980, Geologic cross-section of the central Oregon continental margin: Geol. Soc. Amer. Map and Chart Series $M C-28 \mathrm{~J}, 8 \mathrm{p}$. 
Snavely, P. D., Jr., Wagner, H. C., and Macleod, N. S., 1969, Geology of western Oregon north of the Klamath Mountains, in Mineral and Water Resources of Oregon: Ore. Dept. Geol. and Min. Ind. Bull. 64, p. 3246 .

Stewart, R. E., 1956, Stratigraphic implications of some Cenozoic Foraminifera from western Oregon. Oligocene-Eocene: The Ore Bin, v. 18, n. 7, p. 56-63.

Stewart, R. E., 1957, Stratigraphic implications of some Cenozoic Foraminifera from western oregon. Eocene: The Ore Bin, v. 19, n. 2, p. 11-15.

Thoms, R. E., 1959, The geology and Eocene biostratigraphy of the southern Quimper Peninsula area, Washington: Unpub. M. S. thesis, Dept. Geol., Univ. Wash., $103 \mathrm{p} ., 7 \mathrm{pl} ., 20 \mathrm{fig}$.

Thoms, R. E. 1969, Paleontological examination of four deep wells in northwestern oregon, p. 39-46. In $V$. C. Newton, Jr., Subsurface geology of the lower Columbia and Willamette Basins, Oregon. Oreg. Dep. Geol. Miner. Ind., Oil and Gas Invest. 2 .

Thoms, R. E., 1975, Biostratigraphy of the Umpqua Group, southwestern oregon: Pacific Section, AAPG-SEPM Symposium, p. 513-562, 4 pl., $8 \mathrm{fig}$.

Timmons, D. M., 1981, Stratigraphy, lithofacies and depositional environment of the Cowlitz Formation, T. 4 and 5N., R.SW., northwest oregon: Portland state University, unpublished masters thesis, $89 \mathrm{p}$.

Van Atta, R. O., 1971, Sedimentary petrology of some Tertiary formations, upper Nehalem River basin, Oregon: Oregon State Univ., Corvallis, unpub. doctoral disseration, $245 \mathrm{p}$. 
Warren, W., and Norbisrath, H., 1946, Stratigraphy of the upper Nehalem River basin, northwestern oregon:

Amer. Assoc. Petroleum Geol. Bull., v. 30, p. 213237 .

Warren, W., Norbisrath, H., and Grivetti, R. M., 1945, Geology of northwestern oregon west of the Willamette valley and north of latitude 45 15': U. S. Geol. Survey Oil and Gas Inv., Preliminary Map \#42.

Wells, F. G., and Peck, D. L., 1961, Geologic map of Oregon west of the l2lst meridian: U. S. Geol. Survey Inves., Map I-325. 